\title{
Marine Palynomorphs from the Plio-Pleistocene interval of the AND-1B Drill-Core McMurdo Sound, Antarctica
}

Rory Matthew Mearns

\author{
A thesis submitted to Victoria University of Wellington \\ in fulfillment of the requirements for the degree of \\ Masters of Science in Geology
}
School of Geography, Environment and Earth Sciences
Victoria University of Wellington

November 2010 


\section{ABSTRACT}

The ANDRILL project recovered over $600 \mathrm{~m}$ of Plio-Pleistocene sediments within the Ross embayment, Antarctica. These sediments contain a record of local and regional paleoenvironmental conditions and glacial dynamism. They also provide a proxy for ice dynamics of the West Antarctic Ice Sheet (WAIS) during a period when global temperatures were $\sim 3^{\circ} \mathrm{C}$ higher than modern. This unique record provides an analogue for future global climate change, which is expected to rise by $3^{\circ} \mathrm{C}$ by the end of the $21^{\text {st }}$ century.

Sixty-one samples from the upper $600 \mathrm{~m}$ of the AND-1B core were analysed for their palynomorph content yielding 4 to 5380 grains per sample (with an average frequency of 34 grains per gram). Marine palynomorphs including fossil dinoflagellate cysts, acritarchs, and prasinophyte algae were the focus of this study and fluctuations in their abundance and diversity reflect changes in paleoenvironment and glacial dynamics.

The upper $600 \mathrm{~m}$ can be divided into 6 discrete units based on the palynomorph assemblage: The early-Pliocene ( 5.0 - 4.6 Ma. Unit 1$)$ is characterised by relatively high abundances of in situ round brown dinoflagellate cysts, microforaminiferal linings, and Leiosphaeridia, suggesting warmer than modern paleoenvironmental conditions and seasonal ice within the Ross embayment. The WAIS was likely small and highly dynamic during Unit 1 . The mid-Pliocene ( 4.6 - 3.4 Ma. Unit 2) exhibits relatively high abundances of round brown dinoflagellate cysts, microforaminiferal linings, and scolecodonts. The relatively low abundance of Leiosphaeridia (understood to indicate proximal/seasonal ice) suggests that ice free conditions at the drill site may have existed for up to $\sim 1.2 \mathrm{Ma}$ and that this may be the warmest period recorded in the core. During the warm, mid-Pliocene interval a sudden increase in scolecodonts (fossilized polychaete remains) may give indications into the water depth at the drill site because of their 
dependence on physical disturbance (decreasing with depth) for population growth. Further study of the scolecodonts is required before confident estimates of water depth can be made. The mid- to late-Pliocene $(\sim 3.4-2.6 \mathrm{Ma}$. Units 3,4 \& $)$ is characterised by a variable palynomorph assemblage indicating variability in paleoenvironmental conditions, ice cover at the drill site, and ultimately a variable WAIS. A spike in the prasinophyte alga Cymatiosphaera (understood to indicate reduced salinity) at the base of a diatomite unit in the late-Pliocene may be a record of algae thriving in meltwater from the collapse of the WAIS. Further highresolution analysis is needed to help resolve this event. The Quaternary interval ( $2.6 \mathrm{Ma}$ and younger. Unit 6) is significantly different from previous units and is dominated by reworked Eocene dinoflagellate cysts and acritarchs (the "Transantarctic Flora"). This interval records a period of significant cooling and glacial expansion and the WAIS likely grew to its modern "polar" state. The WAIS may have undergone several collapses during super-interglacial periods in the Pleistocene but if it did it did not persist in its collapsed state for significant periods of time. 


\section{ACKNOWLEDGEMENTS}

I wish to acknowledge and thank those who have contributed to this thesis:

First, I'd like to thank my supervisors Dr. Mike Hannah and Dr. Tim Naish for their encouragement and wisdom. Thank you Mike, for the constant mentoring on microscope techniques and species identification. And thank you for reading my thesis... again and again.

Many thanks to the Antarctic Research Centre and ANDRILL for the fascinating project, it has been exciting to be part of. Also thank you for the financial assistance, and the opportunities to expand my knowledge at conferences, workshops and on courses. Thank you also to the other ANDRILL members who generously gave me unpublished work to contemplate.

Thank you Claire Storkey for lending me resources from your overwhelming library. Jill Ruthven, you made visiting the library fun. Also thank you Ian Raine for your assistance.

I'd like to thank the past and present occupants of CO305. Katie, Matt, Sam, Skinner \& Tom. You took me on field trips, read my work, found things for me and made me laugh. You're all mad! Also thank you Iain Allen for your help and interesting conversations.

Last but not least I'd like to thank Ruth, Louise and my parents, for so much support over the years. 
TABLE OF CONTENTS

ABSTRACT I I

ACKNOWLEDGEMENTS III

TABLE OF CONTENTS IV

$\begin{array}{ll}1.0 \text { INTRODUCTION } & 1\end{array}$

1.1 ANTARCTIC CENOZOIC HISTORY 3

1.2 DRILLING EFFORTS IN THE WESTERN ROSS SEA REGION 5

2.0 THE ANDRILL PROJECT

2.1 THE ANDRILL PROJECT OVERVIEW 13

$\begin{array}{ll}2.2 \text { LOCATION AND TECTONIC HISTORY } & 18\end{array}$

2.3 THE MODERN MCMURDO ENVIRONMENT 22

2.4 RESULTS FROM THE MCMURDO ICE SHELF PROJECT 24

3.0 PALYNOLOGY METHODS 29

3.1 SAMPLE PREPARATION 29

3.2 MICROSCOPE AND CAMERA TECHNIQUE 30

3.3 SAMPLE COUNTING 30

3.4 SPECIES IDENTIFICATION 31

3.5 CONTAMINATION 31

3.6 GRAPHING AND GRAPHICS 31

4.0 RESULTS, PALYNOLOGICAL OVERVIEW \& INTERPRETATIONS 32

4.1 PALYNOMORPH ASSEMBLAGES 33

4.2 DIVERSITY AND ABUNDANCE 38

4.3 LONG TERM TRENDS 39

4.4SHORT TERM TRENDS 42

5.0 INTEGRATION AND DISCUSSION

5.1 SYNTHESIS OF ANTARCTIC AND GLOBAL CLIMATE STUDIES 56 
$\begin{array}{ll}\text { 7.0 REFFERENCES } & 67\end{array}$

APPENDIX A TAXONOMIC CHECKLIST \& NOTES

APPENDIX B Palynomorph Study of ANDRILL Gravity Cores from McMurdo Sound, Antarctica.

\section{LIST OF FIGURES}

01 LOCATION MAP OF THE WEST ANTARCTIC RIFT SYSTEM AND THE

MCMURDO AREA 2

02 GLOBAL DEEP-SEA OXYGEN AND CARBON RECORDS 4

03 SUMMARY OF ANDRILL AND-1B CORE STUDIES 17

04 LOCATION ILLUSTRATION AND GEOLOGIC SETTING 20

05 PALYNOMORPH DISTRIBUTION IN AND-1B CORE (PERCENTAGE) INSERT 06 PALYNOMORPH DISTRIBUTION (GRAINS PER GRAM) INSERT 07 INTERPRETATION OF PALYNOMORPH RESULTS INSERT 08 PALYNOMORPHS INDICATING PALEOENVIRONMENTAL CONDITIONS 48 09 SYNTHESIS OF PALYNOMORPH RESULTS \& ANTARCTIC STUDIES INSERT 10 SYNTHESIS OF ANTARCTIC AND GLOBAL CLIMATE STUDIES INSERT

\section{PLATES}

01 DINOFLAGELLATA 85

02 DINOFLAGELLATA 86

03 DINOFLAGELLATA PRASINOPHYCEAE ACRITARCH MICROFORAMINIFERA SCOLECODONTS AND TERRESTRIAL $\quad 87$ 04 OTHER PALYNOMORPHS 
TABLES

01 PALYNOMORPH COUNTS 89

O2 PALYNOMORPH PRECENTAGES 90

03 PALYNOMORPH GRAINS PER GRAM 91 


\subsection{INTRODUCTION}

Presented here is a study of marine palynomorphs from the upper $600 \mathrm{~m}$ of the ANDRILL AND-1B core drilled in Windless Bight, McMurdo, Antarctica (Figure 1). This study contributes to the primary objective of the ANDRILL project: to detail the history of paleoenvironmental change in the Antarctic region and develop a more precise understanding of the ice dynamics of the Antarctic ice sheets and shelves. The AND-1B core penetrated 1285 meters below sea floor (mbsf) and recovered a relatively continuous sediment package covering the Pleistocene, Pliocene and Late-Miocene time periods. The upper $600 \mathrm{~m}$ of this core, the focus of this study, covers the Plio-Pleistocene time periods.

The marine palynomorphs examined in this study are microscopic marine organisms (predominantly dinoflagellates, acritarchs and prasinophyte algae) that fluctuate in their diversity and abundance depending on their surrounding environmental conditions. Reworked palynomorphs are also examined in this study as their reworking provides insight into local and regional ice dynamics.

The aims and objectives of this study are:

1) To identify and record all marine palynomorphs in the upper $600 \mathrm{~m}$ of the AND-1B core at a sample resolution of no coarser than 1 sample every $10 \mathrm{~m}$.

2) To identify trends and patterns in the palynomorph assemblage and to interpret them in terms of paleoenvironmental/ecological significance and to use these interpretations to identify a paleoenvironmental history on a local (Windless Bight) and regional (Ross Sea) scale.

3) To integrate the findings and results with other Antarctic and high latitude studies. 
b)

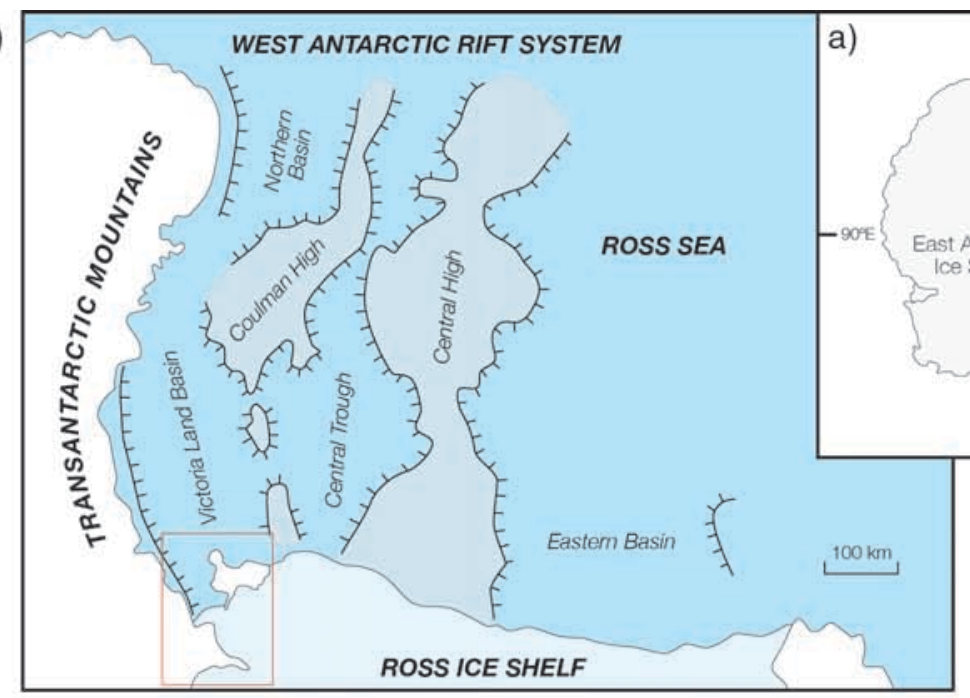

$T_{180^{\circ}}$
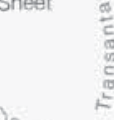

LEGEND

\&. W. Antarctic ice Sheet $90 \mathrm{w}-$

- ANDRILL Sites

- Previous McMurdo Sound Drill Sites

- Elevation/Bathymetric Contour $(200 \mathrm{~m})$

c)

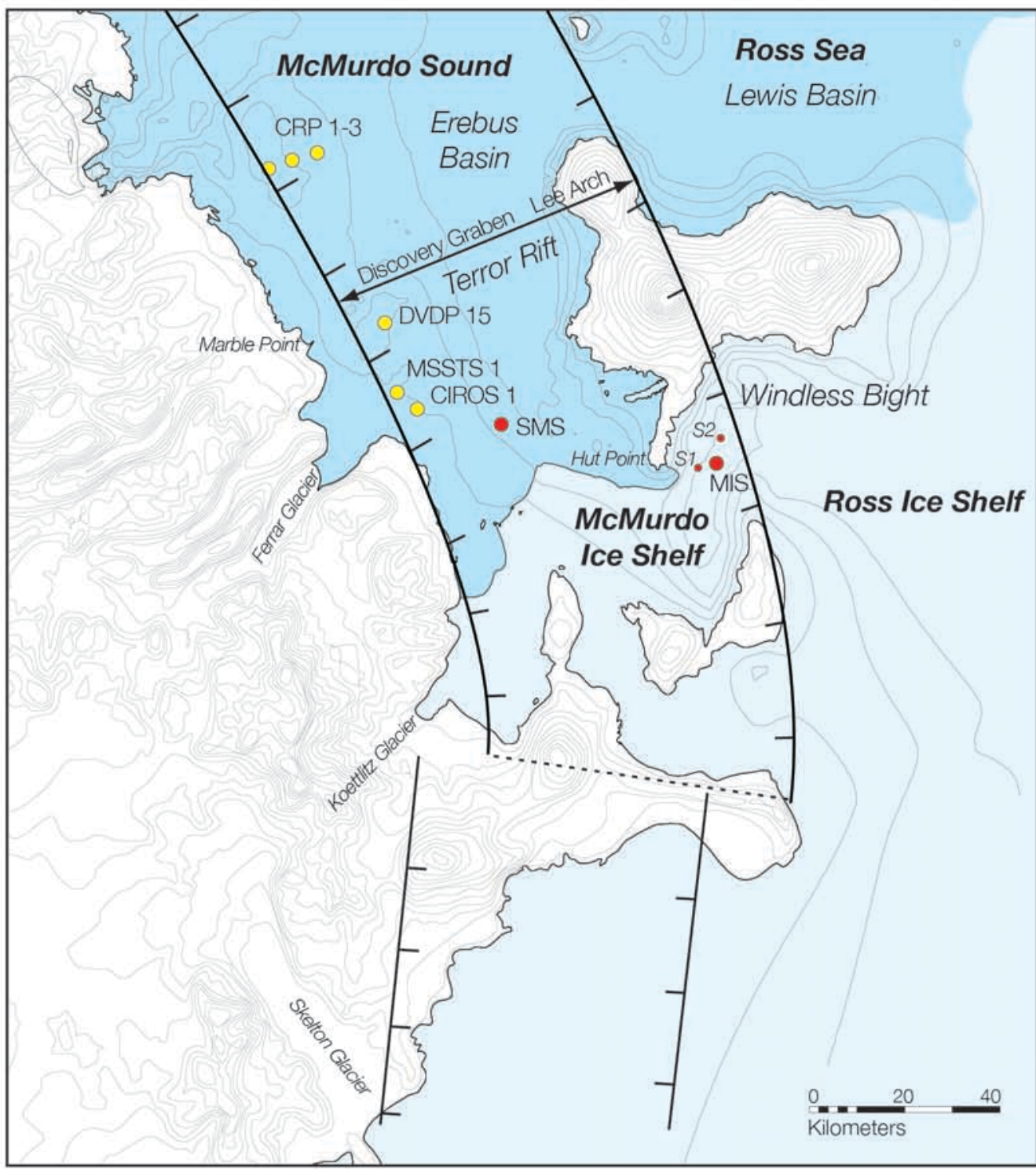

FIGURE 01 Location map of the West Antarctic Rift System (a \& b) and the McMurdo area (c). Illustrated in map $c$ is the Terror Rift and the locations of drilling efforts in the area including the ANDRILL MIS \& SMS drill sites and two gravity core sites studied in preparation for the MIS project (Site 1 [S1] and Site 2 [S2]). 


\subsection{ANTARCTIC CENOZOIC HISTORY}

Despite being in its current polar position since the Late-Cretaceous times there is no evidence of the presence of ice on the Antarctic continent between the Permian and the Late-Paleocene to the Mid-Eocene ( $40 \mathrm{Ma}$ ). Evidence from the Mid-Eocene period, consisting of isolated sand in fine-grained sediment and lonestones, suggests ice calving around the continent that may have originated from glaciers and not necessarily continental ice sheets. However several large fluctuations in the eustatic sea-level curve also occur during the Early- to Mid-Eocene suggesting the possible presence of temporary continental ice sheets on the Antarctic continent (Barrett, 1999).

In the Early-Oligocene a significant positive shift in the global oxygen isotope record (Figure 2) is observed and is best explained by the formation and development ice sheets on the Antarctic continent that preferentially remove and store light oxygen isotopes from the oceans. Several locations of study around Antarctica (Ross Sea [DSDP 270], McMurdo Sound [MSSTS-1, CIROS-1] and Prydz Bay [ODP 739 \& 742]) show evidence of a changing style of sedimentation with more debris of glaciogenic origin. This evidence indicates an increased, but unstable, ice volume on the Antarctic continent. 


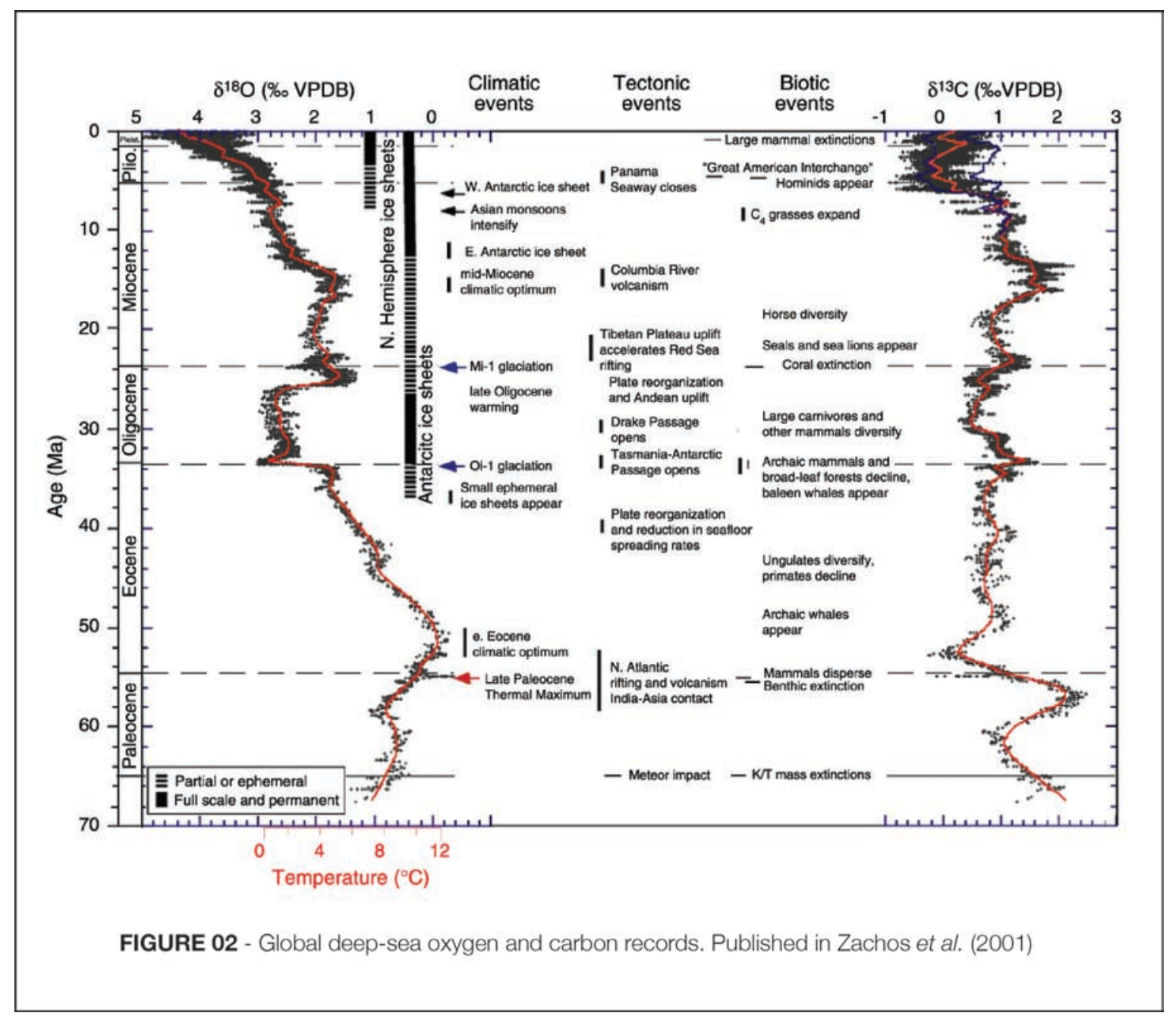

Some authors (Barrett, 1999) attribute the formation of ice sheets on the Antarctic continent to the thermal isolation of the continent from the northward drift of the Australian continent in the Early-Oligocene and the northward drift of South America by the Early-Miocene creating the Antarctic Circum Polar Current. Others (DeConto \& Pollard, 2003), suggest that falling atmospheric $\mathrm{CO}_{2}$ levels allowed small isolated icecaps to build up on high Antarctic topography. Further reduction in $\mathrm{CO}_{2}$ and variations in the Earth's orbital parameters that alter polar insulation caused these ice caps to expand and initiate climate feedbacks that accelerate the ice expansion. Eventually the ice caps joined to form the Antarctic ice sheets.

Oxygen isotopes (Figure 2) show a significant increase in ice volume on Antarctica in the MidMiocene (Barrett, 1999). The East Antarctic Ice Sheet (EAIS) is believed to have reached a 
steady state around this period and remained this way to the present. The discovery of marine diatoms high in the Transantarctic Mountains has led some authors to suggest dramatic collapses of the EAIS during the last $3 \mathrm{Ma}$ (Webb et al. 1984), but this has since been successfully contested by the discovery of aeolian processes that regularly transport diatoms into the high Antarctic regions (McKay et al. 2008).

The West Antarctic Ice Sheet (WAIS) is considered less stable than the EAIS (McKay et al., 2008) because it is a marine based ice sheet, as opposed to the land based EAIS, making it more susceptible to melt events resulting from changes in temperature. A recent study has shown that the WAIS can transit from a fully glaciated state to a collapsed state in only several thousand years with major retreats occurring in much less time (Pollard \& DeConto, 2009). The WAIS has an ice volume equivalent to $\sim 5 \mathrm{~m}$ of sea level rise so understanding its precise vulnerability is of significant interest when considering recent global warming projections (Clark \& Huybers, 2009). Modern Antarctic studies have concentrated on the dynamics of the WAIS and the paleoenvironment during glacial maxima and minima. This study aims to contribute to both of these areas through the use of marine microfossils (palynomorphs) from the McMurdo region that were deposited during the Pliocene and Pleistocene and recovered by the ANDRILL McMurdo Ice Shelf project (MIS).

\subsection{DRILLING EFFORTS IN THE WESTERN ROSS SEA REGION}

Over the past few decades there have been numerous drilling efforts in the Ross Sea, McMurdo and surrounding areas with varying degrees of success. The earliest effort was the Deep Sea Drilling Project (DSDP) Leg 28 in the early 1970's that drilled several cores in the Ross Sea. The 
first ice based drilling effort in the region was the Dry Valley Drilling Project (DVDP) 15 in 1975. Following this were several ice based drilling efforts that improved drilling technology and techniques significantly, allowing much greater depths to be reached and more core to be recovered. The current technology, such as that used in the ANDRILL project, can drill through a $>250 \mathrm{~m}$ ice platform floating $>1000 \mathrm{~m}$ above the sea floor and recover over $1000 \mathrm{~m}$ of sediment.

Cores recovered from the region have been used to assess the tectonic, climatic, and glacial history of Antarctica and its influence on sea level, ocean currents, and global climate. More recently, with growing interest in global climate dynamics, Antarctica has become a focus for understanding the thresholds and consequences of fluctuations in global temperature. The inception of the southern polar ice sheet (EAIS \& WAIS), its subsequent expansions and contractions, and the ice dynamics involved are of particular scientific interest because of the significant effect they have on climate feedback, ocean currents and sea level. Previous drilling efforts in Antarctica have failed to retrieve a continuous Pliocene to Pleistocene sediment record. Instead most drilling projects have successfully recovered Miocene to Oligocene sediment records along with fragmented Pliocene to Pleistocene records.

The westernmost regions of the Ross Sea and McMurdo area have repeatedly been selected as the preferred location of study because of the accommodation space provided by the subsidence of the Victoria Land Basin and the continual sediment supply provided by the adjacent uplifting Transantarctic Mountains (TAM) which allows for the deposition of a more or less continuous sediment record of the Antarctic paleoenvironment over the last $31 \mathrm{Ma}$. The proximity to McMurdo Station and Scott Base also allows for close logistical support.

A list of the drilling efforts in the western Ross Sea region are listed below in chronological order accompanied by a brief overview of the project and results. 


\section{Deep Sea Drilling Project (DSDP) Leg 28 (Hayes \& Frakes, 1975)}

Leg 28 is one of the four Deep Sea Drilling Project (DSDP) drillinglegs made to the southern high latitudes in the 1970's to study the history of the Antarctic ice sheets and the surrounding environment. This leg took place between late 1972 and early 1973 and drilled eleven different sites and recovered $1405 \mathrm{~m}$ of core in total. The non-continuous sediments recovered ranged from Oligocene to Quaternary in age. Four of the eleven sites (Sites: 270, 271,272 and 273) were situated on the Ross Sea continental shelf. Results from these studies provided significant insight into the history of Antarctic glaciation. Ice rafted debris data from these sites indicate that the glacial history in the Ross Sea region began in the Late-Oligocene $(\sim 20 \mathrm{Ma})$ at the earliest. Evidence from erosion, bottom currents recorded in the sediment and ice rafted debris also suggest a rapid glacial expansion in the late-Miocene/early-Pliocene.

\section{Dry Valley Drilling Project (DVDP) 15 (Barrett et al., 1976)}

DVDP 15, in 1975, was the first attempt at sampling sediments within the McMurdo Sound. The drill site is located east of Marble Point (Figure 1) and is the first core to be drilled using seasonal sea ice as a drilling platform. The water beneath the $2 \mathrm{~m}$ thick ice platform was $122 \mathrm{~m}$ deep. The aim of the operation was to penetrate Cenozoic glacial sediments estimated to be $\sim$ $300 \mathrm{~m}$ thick, and investigate the history of the East Antarctic Ice Sheet (EAIS).

The drill only penetrated 65 mbsf before it was terminated because of a crack in the ice that threatened to fracture the sea-ice drilling platform. The core was split into two units: Unit 1 (0 $13 \mathrm{mbsf}$ ) was interpreted to be recent deposits, while Unit $2(13-65 \mathrm{mbsf})$ was interpreted to be Pleistocene in age. The older (Miocene \& Oligocene) glacial deposits first identified on 
DSDP Leg 28 were not reached.

\section{McMurdo Sound Sediment and Tectonic Studies (MSSTS)-1 (Barrett, 1986)}

MSSTS-1 (Figure 1), drilled in 1979, was the first attempt to drill through the glacial sequence into the pre-glacial sediment in McMurdo Sound. Drilled over $195 \mathrm{~m}$ of water it managed to reach a total depth of $227 \mathrm{mbsf}$, but the pre-glacial sediments were not reached. The glaciogenic sediments recovered were dated Late-Oligocene to Early-Miocene in age and the top $50 \mathrm{~m}$ of the core contains a packet of Early-Pliocene and Quaternary sediments. Low diversity and abundance assemblages of palynomorphs were recovered (Truswell, 1986). The palynomorphs proved to be little use for age determination as the recovered specimens were mostly reworked from older sediments. Reworked dinoflagellate cysts were typical high-latitude Eocene dinoflagellates including Spinidinium macmurdoensis, Vozzhennikovia apertura, Vozzhennikovia rotunda, and Deflandrea antarctica (Wrenn \& Hart, 1988). Reworked terrestrial palynomorphs (spores and pollen) also occur in the core and are Permian to Cretaceous in age. The proximity of the MSSTS-1 drill site to the Antarctic coast made it a good site for recording the presence of nearby terrestrial vegetation, but in situ terrestrial palynomorph abundance and diversity was very low suggesting that nearby areas of land bore very little vegetation.

Cenozoic Investigations of the western Ross Sea (CIROS) (Barrett, 1989; Barrett \& Hambrey, 1992)

Two drill holes were cored as part of the CIROS program: CIROS-1 (Figure 1), was drilled offshore and CIROS-2 inshore in the Ferrar Fjord. The CIROS-1 drill hole was first attempted in 1984 but due to thin ice and other factors it was abandoned. The drilling rig was moved and 
CIROS-2 was drilled. CIROS 1 was redrilled during October and November of 1986 reaching a total depth of $702 \mathrm{mbsf}$. The sediment recovered records two time periods (36 to $34.5 \mathrm{Ma}$, and 30.5 to $\sim 22 \mathrm{Ma}$ ) separated by an unconformity.

From paleontological, mineralogical, and sedimentological evidence the climate at the drill site during deposition is interpreted to be temperate with “...beech forest [and] podocarps, proteas and other shrubby angiosperms." (Barrett, 1989, p. 244) Evidence also suggests that this flora persisted through several of the Oligocene glacial events. Striated and faceted stones found within the core indicate the presence of glaciers near the drill site.

The marine palynomorphs reported from the core (Wilson, 1989) are a distinct Late-Eocene flora (which was considered to be the result of reworking). The most common species include: Vozzhennikovia apertura, Vozzhennikovia rotunda, Alterbidinium asymmetricum, Alterbidinium distinctum, Arachnodinium antarcticum, Areosphaeridium cf. dictyoplokus, Deflandrea antarctica, Spinidinium macmurdoense, Turbiosphaera filosa.

CIROS-2 was drilled at the foot of the Ferrar Glacier in the Ferrar Fjord. Here the glacier has cut a U-shaped valley through the Transantarctic Mountains in a SW to NE direction. The Ferrar Glacier is fed from the Polar Plateau therefore sediments transported by the glacier and deposited into the Ferrar Fjord record fluctuations in East Antarctic ice volume. The CIROS-2 core reached a depth of $166 \mathrm{~m}$ where it finally penetrated basement gneiss.

The CIROS-2 core can be split into two sequences. The lower sequence (100 - $162 \mathrm{mbsf})$ is Pliocene in age $(4.9-2.0 \mathrm{Ma})$ and records several periods of ice advance and retreat through the Transantarctic Mountains and down into the Ferrar Fjord. The upper sequence, 100 mbsf to core top, is Pleistocene in age and records a period when the glacier was starved of ice, and the deposited sediments were primarily aeolian and glacial sediments from the incursion of grounded Ross Sea ice. Barrett and Hambrey (1992) attribute the retreat of ice from the valley, 
and subsequent change in style of sedimentation, to the uplift of the Transantarctic Mountains around this time. No palynomorphs were recovered from the CIROS-2 core.

\section{Cape Roberts Project (CRP) - 1 (Hambrey et al., 1998)}

Three drill holes were cored as part of the Cape Roberts drilling project. The aim was to obtain a continuous core containing strata ranging from 30 to $100 \mathrm{Ma}$ in age. The drill sites are located 13 to $16 \mathrm{~km}$ to the east of Cape Roberts (Figure 1). The sediments drilled dip eastwards into the Victoria Land Basin, allowing older sediments to be cored by moving the subsequent drill site westward where the younger sediments thin.

Drilling CRP-1 was planned for 1996 but was postponed to 1997 because of unfavorable ice conditions. Drilling had to be terminated after only 7 days due to severe weather and ice breakouts rendering the drill rig unsafe for further drilling. The core managed to reach a total depth of $148 \mathrm{mbsf}$. The upper part of the core was unconsolidated and brecciated and the core recovery averaged $68 \%$. This rose to $98 \%$ below $100 \mathrm{mbsf}$. The core penetrated Pleistocene sediments, $1.2-1.8 \mathrm{Ma}$ in age $(0-43 \mathrm{mbsf})$, and then an early-Miocene interval (43- 148 mbsf) where the oldest sediments recorded at the base are $22-24 \mathrm{Ma}$ in age. All of the sediments recovered are interpreted to be of glaciomarine origin.

Hannah et al.(1998) identified prasinophyte algae as the most common marine palynomorph encountered in the CRP-1 core. Acritarchs are noted as being common in many samples, the dinoflagellate cyst Lejeunecysta fallax occurs in relatively high abundance and the overall dinocyst diversity throughout the core is low. The following reworked dinoflagellate species were also present in the core; Vozzhennikovia apertura (the most common), Alterbidinium cf. asymmetricum, Deflandrea antarctica, Crassosphaera sp., Operculodinium bergmannii, and Spinidinium macmurdoense. 


\section{CRP-2/2A (Fielding \& Thomson, 1999)}

CRP-2/2A is located several kilometers to the west of the CRP- 1 drill site where it penetrated sediments overlapping in age and older than those encountered in the CRP-1 core. Drilling in late 1998 CRP-2/2A, situated on a $2 \mathrm{~m}$ thick sea ice platform floating $178 \mathrm{~m}$ above the sea floor, reached a total depth of $624 \mathrm{mbsf}$, coring sediments 33 - $35 \mathrm{Ma}$ in age and younger. At the core top the youngest strata are early-Miocene in age and overlap with the deepest sediment cored in CRP-1. Below the overlap, the sediments extend to early-Oligocene in age and are interpreted as cyclic glaciomarine. Terrestrial palynomorph data (Askin \& Raine, 2000) suggests that the inferred "low diversity woody vegetation" of the early-Oligocene (below 300 mbsf) is of a milder climate than during the late-Oligocene and younger (above $300 \mathrm{mbsf}$ ) which is interpreted to be a low growing sparse tundra (Askin \& Raine, 2000).

Hannah et al. (2000) analysed the marine palynomorphs from the CRP-2/2A core and found three distinct groups; prasinophytes, acritarchs and dinoflagellate cysts. Of the dinoflagellate cysts recovered, the most abundant in situ genus was Lejeunecysta, and the most abundant reworked species were Enneadocysta partridgei, Vozzhennikovia apertura and Deflandrea antarctica all of which are part of the well documented Eocene/earliest Oligocene dinocyst assemblage referred to as the Transantarctic Flora (Wrenn \& Hart, 1988).

\section{CRP-3 (Barrett, Sarti, \& Wise, 2000)}

CRP-3 was the third and final drill hole of the Cape Roberts Project and was located to the west of CRP-2/2A (Figure 1) and aimed to sample the youngest non-glacial strata in the Victoria Land Basin while overlapping the lower strata of CRP- 2/2A. The drilling took place in 
late 1999 and, drilling from a 2 m sea ice platform through $295 \mathrm{~m}$ of water, cored to a depth of 939 mbsf. It is noted that there is possible underlap between CRP- 2/2A and CRP- 3, in the order of tens of meters. The strata recovered were mostly early-Oligocene in age representing $\sim 3$ m.y. (31 - 34 Ma).At 823 mbsf Devonian sandstone basement rock (Beacon Group) was encountered and the pre-glacial Cenozoic strata were not encountered.

Barrett et al. (2000) describe the Oligocene age basin fill resting on the Devonian Beacon Supergroup as tectonically significant for three reasons: 1) The sediment originally overlying the Devonian Beacon Supergroup must have been eroded prior to or during the down-faulting of this rock, 2) the age of the Cenozoic strata overlying the basement rock is likely to have been deposited during the major rifting phase of the Victoria Land Basin (Section 2.2) and 3) the Beacon basement strata can be matched to the Beacon strata in the adjacent Transantarctic Mountains which suggests a displacement of $c .3000 \mathrm{~m}$ down to the east.

The terrestrial palynomorphs present are low in abundance and diversity giving evidence of a cold climate that persisted at the CRP - 3 site from Early-Oligocene time (Barrett et al., 2000). A clay mineral assemblage indicative of a modern high latitude sedimentation style supports this interpretation.

Marine palynomorphs occur in moderate abundance and diversity in the upper $\sim 160 \mathrm{~m}$ of the core. Below $160 \mathrm{mbsf}$, abundance and diversity is reduced and below $324 \mathrm{mbsf}$ samples are either barren or have very sparse assemblages. Marine palynomorphs identified are largely dinoflagellate cysts (in situ and reworked) and prasinophyte algae with a presence of acritarchs also (Barrett et al., 2000; Prebble et al., 2006). 


\subsection{THE ANDRILL PROJECT}

\subsection{THE ANDRILL PROJECT OVERVIEW}

ANDRILL (ANtarctic geological DRILLing Program) is an international Antarctic scientific drilling effort involving scientists from Germany, Italy, New Zealand and the United States. The program began with two drill holes, one from beneath the McMurdo Ice Shelf (MIS Project) in Windless Bight (Figure 1), the second taken from the southern McMurdo Sound region(SMS Project). The drilling operation for the MIS Project was successfully undertaken in late 2006 (core AND-1B) and forms the basis of this thesis. Drilling for the SMS Project was successfully completed in late 2007.

The main objective of the ANDRILL program is to investigate Antarctica's role in global environmental change over the past 65 million years. By undertaking a multi-disciplinary study on cores retrieved by the program, a better understanding can be gained about the complex way in which the Antarctic ice sheets interact with the Earth's climate. This includes an increased understanding of how the Antarctic ice sheets developed, how stable they are, and their direct effect on climate and sea level. An improvement in the understanding of the dynamics of the Antarctic ice sheets mean that valuable predictions can be made about Antarctica's role in future climate change. The program also aims to improve the knowledge of polar biota, the West Antarctic Rift, and the uplift of the Transantarctic Mountains. 
Core Recovery (Falconer $e$ al. 2007)

Drilling of the AND-1B core in Windless Bight (Figure 1) began in October 2006 and the coring was completed on 26 December 2006. The ice-shelf thickness was estimated to be $82 \mathrm{~m}$ and the depth to sea floor was $\sim 936 \mathrm{~m}$.

Recovered core was cut into $1 \mathrm{~m}$ lengths, packaged and transported to McMurdo station where initial investigations were carried out before it was packed and shipped to its final destination at the Antarctic Research Facility at Florida State University in the United States. Several investigations were also carried out at the drill site on the core and also the core hole.

The recovered core was $1284.87 \mathrm{~m}$ in length and spans the last 13 million years.

Initial Sedimentology, Stratigraphy and Paleontology (Krissek et al., 2007; Scherer et al., 2007)

The core recovered contained a range of lithologies including diamictites, sandstones, mudstones, diatomites and volcanic ash, tuff and lava flow. Eleven lithofacies have been recognised including open marine diatomites, mudstones, turbidites, and ice-proximal massive and stratified diamictites. Initial investigations of the strata show evidence of repeated glacial advance and retreat, and more than 60 glacimarine sequences bounded by glacial surfaces of erosion were documented. Three distinct stratigraphic-cycle motifs are recognised in the core (further developed in Section 2.4): Motif 1 is dominated by diamictite and represents a glacial advance and retreat cycle. The top of this cycle is truncated in this motif by the erosion of advancing ice. Motif 2 consists of basal diamictite overlying a glacial surface of erosion (GSE). The diamictite then grades up through more distal glacimarine deposits and into diatomites indicating open water. The upper half of Motif 2 exhibits advancing ice deposits and grades back into diamictite that is then truncated by a GSE. Motif 2 represents a record of ice advance, 
retreat and then readvance. Motif 3 is similar to Motif 2 except the diatomite is absent and mudstones dominate the upper portion. The uppermost section that represents the ice readvance is absent, thinned or truncated in Motif 3. Motif 3 is most common below $590 \mathrm{mbsf}$ and is not represented in this study.

The paleontology of the core consists of rare calcareous microfossils, abundant diatoms and organic-walled microfossils. The rare calcareous microfossils provide age constraint and paleoenvironmental information through the use of isotope analysis on their calcareous remains. Documented diatoms also provide age control and paleoenvironmental reconstruction. The organic-walled microfossils have assisted in providing insights into sediment reworking and paleoenvironment reconstruction.

\section{Age Model (Wilson et al., 2007)}

The age model for the core was constructed using a variety of data (diatom assemblages, magnetostratigraphy $\&{ }^{40} \mathrm{Ar} /{ }^{39} \mathrm{Ar}$ radiometric dating) but it is only relatively well constrained in the upper $700 \mathrm{~m}$ of the core. Diatom assemblages and datums between 53 and $586 \mathrm{mbsf}$ provide a 0.5 to $1-2$ million year age resolution. Magnetostratigraphic constraints using the Geomagnetic Polarity Time Scale (GPTS) are available between 32 and $700 \mathrm{mbsf} .{ }^{40} \mathrm{Ar} /{ }^{39} \mathrm{Ar}$ ages of volcanic material at $86,113,136 \& 648$ mbsf provide isotopic age constraints at those levels. GSE's throughout the core indicate the punctuated nature of the sediment accumulation, and suggest that significant amounts of time remain unrecorded.

Below $700 \mathrm{mbsf}$ the age model is poorly constrained with only three ${ }^{40} \mathrm{Ar} /{ }^{39} \mathrm{Ar}$ ages currently available on volcanic clasts at $1280 \mathrm{mbsf}$. A maximum age of $13.85 \pm 0.18 \mathrm{Ma}$ is measured from these clasts indicating a Mid-Miocene maximum age for the base of the AND-1B core. 
The latest revision of this model (to $600 \mathrm{mbsf}$ ), with correlation to the global ocean benthic $\delta^{18} \mathrm{O}$ stack, is presented in Naish et al. (2009a). A distilled version of this is used in this study (Figure 3) and is comprised of the magnetostratigraphic boundaries with interpretations and ${ }^{40} \mathrm{Ar} /{ }^{39} \mathrm{Ar}$ dates. 


\section{Lithologic Log}

\& Age Model
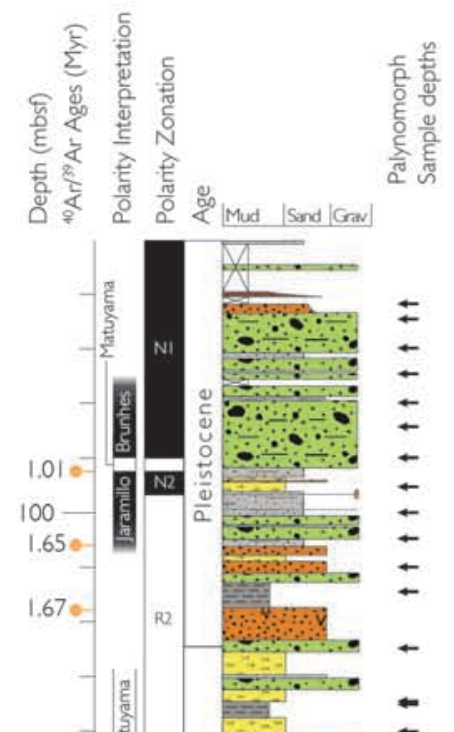

200
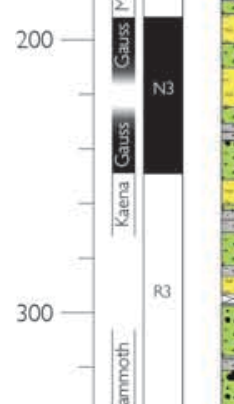

400

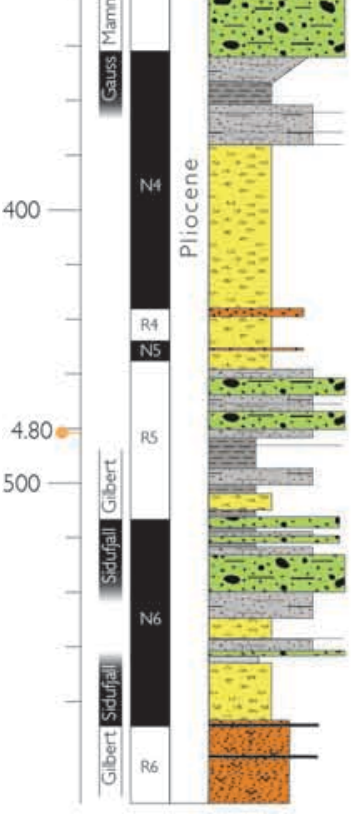

Diatomite

F.: Mud/Sand-stone

调 Siltstone

II Diamictite

Volcanic
Facies Abundance Per Sequence

(excl. diatomite)

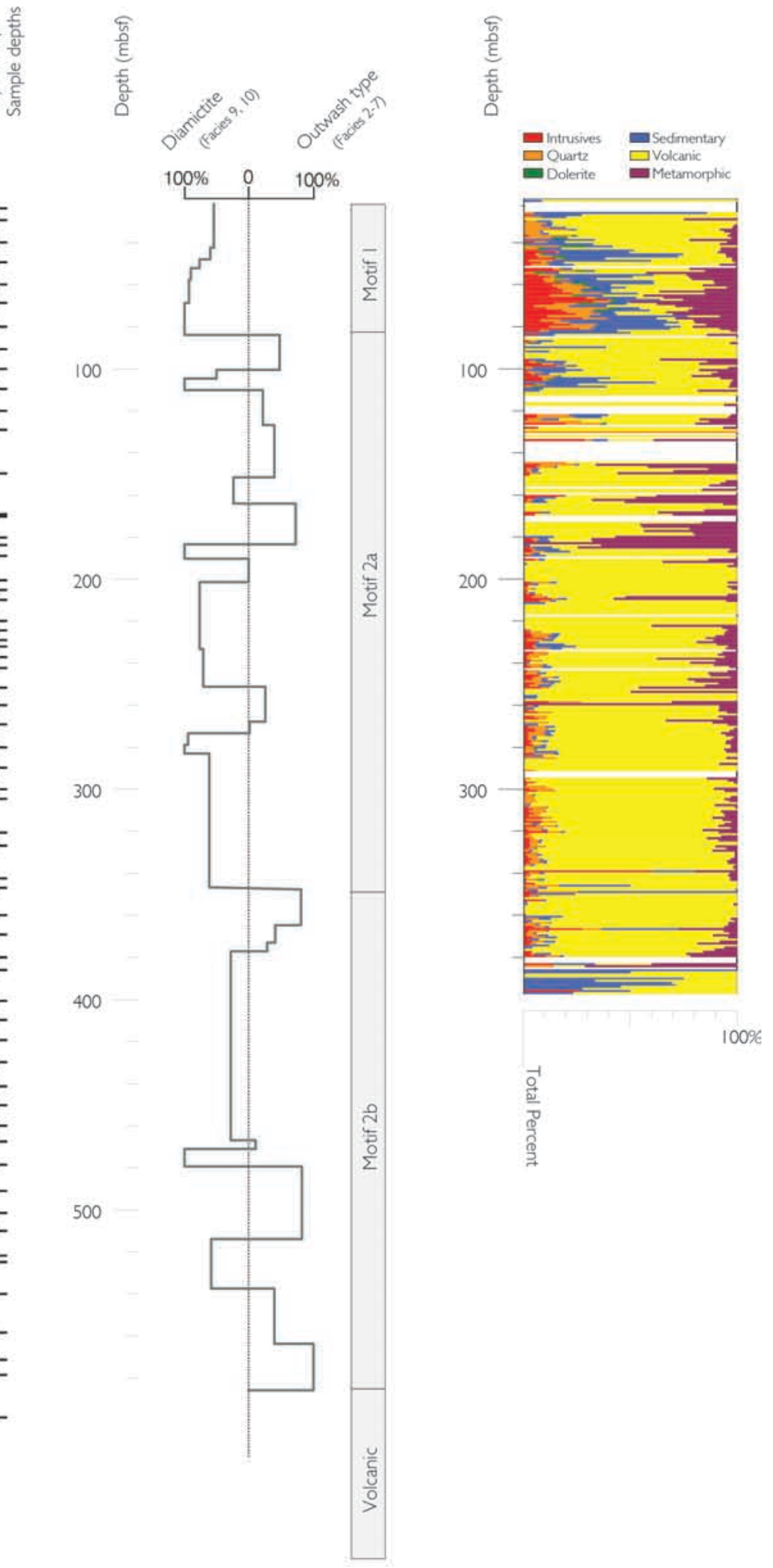

FIGURE 03 Preliminary studies on the AND-1B core including lithology, age model (Naish et al. 2009a) and sample depths for the palynomorph analysis, lithological facies (Mckay et al. 2009) and clast provenance (Talarico et al. 2010) 


\subsection{LOCATION AND TECTONIC HISTORY}

AND-1B is located in Windless Bight, McMurdo Sound. The drill site is situated in a flexural moat created by the Late-Neogene loading of the Ross Island volcanic complex at the southern end of the Terror Rift, a young rift lying within the Victoria Land Basin (Figure $1 \& 4$ ).

\section{Victoria Land Basin}

The Victoria Land Basin is a north-south trending extensional rift basin, $150 \mathrm{~km}$ wide, in the westernmost region of the Ross Sea (Figure 1). Sediments are estimated to be up to $12 \mathrm{~km}$ thick in places (Cooper \& Davey, 1985). The basin runs parallel to the Transantarctic Mountains from the Cape Washington area in the north to at least McMurdo Sound, where it may continue further south (Cooper, Davey \& Behrendt, 1987). The major rifting in the Victoria Land Basin was initiated in the Late-Eocene and is associated with the uplift of the Transantarctic Mountains (Fielding, Henrys \& Wilson, 2006). The processes that caused the rifting are poorly understood, but they are believed to be associated with the regional crustal extension between East and West Antarctica that caused the breakup of Gondwana (Cooper $e$ t al., 1987). In the central section of the Victoria Land Basin lies the Terror Rift, a more recent rift comprised of the Discovery graben and the Lee arch.

\section{Terror Rift}

The Terror rift is an active rift younger than $17 \mathrm{Ma}$ (Fielding et al., 2008). First described by Cooper et al. (1987) the Terror Rift is $50-60 \mathrm{~km}$ wide and is traced along the central Victoria Land Basin from Cape Washington in the north to the Ross Island volcanic complex in the 
south (Figure 1) but, like the VLB it may continue and trace further south, under the Ross Ice Shelf. The rift is made up of two parallel structures: (1) The Discovery graben in the west, a down-faulted graben with faults that have been displaced by up to $3 \mathrm{~km}$ at depth; (2) the Lee arch in the east, a bathymetric and structural high, uplifted and formed by volcanic intrusions and submarine volcanic structures. The faults and structures that form the Terror Rift deform all the sedimentary packages within the Victoria Land Basin, so deformation is believed to be still active.

\section{Ross Island Flexural Moat}

The flexural moat (Figure 4) resulted from the formation of the Ross Island volcanic complex during the past 4.6 million years. As the volcanic complex increased in mass the lithosphere responded by flexing downward creating a "moat", or bathymetric low, around the volcanic complex. Horgan et al. (2005) identified three sedimentary packages within the flexural moat corresponding to three separate volcanic episodes during the development of the Ross Island volcanic complex. The first of these episodes formed Mt. Bird between 4.6 and 3.8 Ma, the second formed Mt. Terror between 1.7 and 1.3 Ma and finally, the formation of Mt. Erebus occurred over the last $1 \mathrm{Ma}$. Each eruption event caused lithospheric loading, creating and then deepening the flexural moat surrounding the Ross Island complex. Each event created 300 $400 \mathrm{~m}$ of accommodation space at the site of AND-1B. 


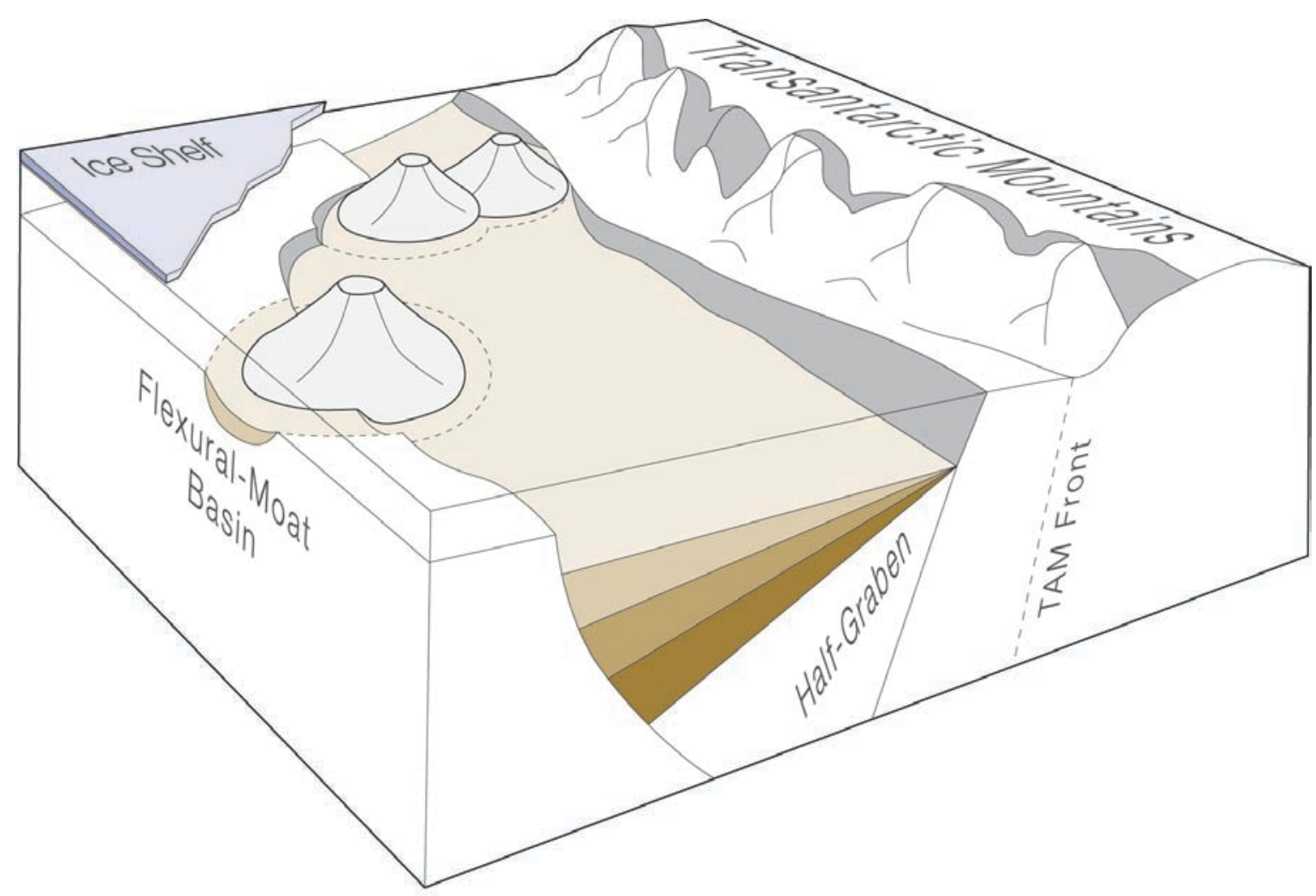

FIGURE 04 Cartoon showing the development of a flexural moat basin superimposed on a rift basin similar to the Ross Island volcanic complex. Adapted from Naish et al. (2005).

\section{History of Rifting in the Victoria Land Basin}

Fielding et al. $(2006 ; 2008)$ outlined the history of the rifting in the Victoria Land Basin by integrating previously drilled cores and seismic data gathered over the 30 years prior. A shortened summary of their interpretation follows:

Phase 1 - Regional Uplift: Early-Cenozoic (Pre-34 Ma): The Transantarctic Mountains undergo a period of major uplift.

Phase 2 - Early Rift: Latest-Eocene to Early-Oligocene (34-29 Ma): This is a period of very rapid subsidence in the Victoria Land Basin and is defined by the first package of sediment confined by grabens. It is noted that this section is buried deeply in 
most areas and often not penetrated by seismic sampling. The early rift sedimentary package approaches the seafloor towards the western margin of McMurdo Sound and was cored multiple times by the Cape Roberts Drilling Project (CRP) (624$443 \mathrm{mbsf}$ in CRP-2A, $823 \mathrm{mbsf}$ to core top of CRP-3) and also the by CIROS-1 (below $366 \mathrm{mbsf}$ ). Deposition is likely marine and includes largely coarse material (conglomerate, breccia, gravel, sand) that often forms subaqueous fans. Sediments are interpreted as being deposited during very rapid subsidence.

Phase 3 - Main Rift: Oligocene (29-23 Ma): The main phase of rifting is reflected in the sediment package extending beyond the horst and graben features that define phase 2. This package is deeply buried in most areas. It is however, regionally extensive and thickens significantly towards the depocentre in the centre of the VLB. The main rift was sampled by CRP-2/2A (443-130 mbsf) and the strata is more lithologically diverse than the early rift sediments. Main rift strata also contain less conglomerates and more diamictites and sandstones than early rift sediments. Cycles of ice advance and retreat were observed throughout the rift sediments and the depositional environment is interpreted to be mainly shallow open marine.

Phase 4 - Thermal Subsidence: Mid- to Late-Miocene (23-13 Ma): This phase is characterized by tabular, sheet-like sedimentary deposits, interpreted to be a result of passive thermal subsidence due to crustal extension. The sediments from the lower portion of the thermal subsidence were sampled by CRP-2/2A (upper 130 mbsf) and CRP-1 (entire pre-Pliocene section). It is noted that a large portion of the upper section of this unit has not yet been sampled by drilling. The lithology is similar to the underlying main rift with an increasing abundance of diamictites up section. Sequences are more condensed that those observed during the main rift 
indicating lower accommodation space from a decreased subsidence rate and possibly increased erosion during glacial advance.

Phase 5 - Renewed Rifting (Terror Rift): ?Mid-Miocene to ?Present (13 Ma-?): This rifting started forming via passive subsidence, this then was interrupted by a structural upheaval. These sediments were the target for the AND-1B drilling project. The renewed rifting sediments thicken toward the central depocentre and are intruded by magmatic rocks.

The lower section of Phase 5 is interpreted to be shallow marine successions and possibly a continuation of the successions documented in the Cape Roberts Drilling Project. The upper part of this phase is sampled by the AND-1B drilling project on the condensed western margin and the sediments are described in detail in this study.

\subsection{THE MODERN MCMURDO ENVIRONMENT}

In late December 2002 to early February 2003, samples of sediment were taken from beneath the McMurdo Ice Shelf in Windless Bight, south of Ross Island, to investigate potential drill site locations for the ANDRILL deep drilling project, and also to study the current sedimentary and oceanographic processes operating under the ice shelf.

The project sampled sediment at two sites situated 5 (Site 1, Figure 1), and 12 (Site 2, Figure 1) kilometers respectively from the shelf edge near Scott Base. At Site 1 the ice shelf is $70.5 \mathrm{~m}$ thick and the sea floor is 920 meters below sea level, Site 2 has an ice shelf thickness of $143.7 \mathrm{~m}$ and the sea floor is $923 \mathrm{~m}$ below sea level. A hot water drill was used to penetrate through the ice. 
The water column was sampled, and then sediment samples were taken from the sea floor using a gravity corer. The results of the studies carried out on the data gathered from these sites (Barrett et al., 2005; Mearns, Appendix B) illustrate the modern depositional environment under the McMurdo Ice Shelf and reveal a palynomorph assemblage dominated by reworked Eocene taxa.

Measurements of the current showed there was a strong correlation between current velocity and the tidal cycle. The net flow is noted to be from McMurdo Sound, to the east into Windless Bight. Coarse sand and gravel occurs in the top few centimeters of the cores retrieved from both sites. Barrett et al (2005) note iceberg rafting as an unlikely explanation and suggest an alternative explanation that these coarse sediments are transported in the iceshelf itself. A study of the diatoms (Barrett et al.,2005) in the top few centimeters of sediment reveals that the majority of the diatoms identified are believed to have come from McMurdo Sound, carried by tidal currents past Hut Point and into the deeper, slower moving waters of Windless Bight. A minor component of glacially reworked diatoms are identified in the sediment as well. A study of the palynology of the samples taken from these sites (Mearns, Appendix B) finds mostly reworked Eocene dinoflagellate cysts (Deflandrea antarctica,Deflandreaflounderensis, Enneadocystapartridgei, Hystrchosphaeridium sp, Spinidinium colemanii, Spinidinium macmurdoense, and Vozzhennikovia apertura) occurring in very low abundances ( $\leq 7$ individual specimens of each species). Two possibly in situ acritarch genera were identified (Micrhystridium and Leiosphaeridia) but both occurred in very low abundance ( $\leq 4$ individual specimens of each genus).Zooplankton and reworked terrestrial palynomorphs were also recorded at these sites in very low abundance. No microforaminiferal linings or prasinophyte algae were identified in the surface and near-surface sediments at either of these two sites. These results of the recent and modern McMurdo environment show that although a water column of 
over $900 \mathrm{~m}$ exists (under a 70+ $\mathrm{m}$ thick ice shelf) in the MIS drill site area, the surrounding waters have very little to no productivity, with no modern dinoflagellate species being preserved in the sediments. This illustrates two points significant to this study; 1) that the absence of in situ dinoflagellate cysts does not indicate ice shelf grounding at the drill site, and 2) that species indicative of productivity are very unlikely to be deposited during periods of permanent ice cover in Windless Bight.

\subsection{RESULTS FROM THE MCMURDO ICE SHELF PROJECT}

Projected anthropogenic warming suggests that global temperatures may rise by $\sim 3^{\circ} \mathrm{C}$ (IPCC 2007). During the Pliocene temperatures regularly reached up to $3^{\circ} \mathrm{C}$ higher than modern (Dowsett et al., 1994; Raymo et al., 2006) and so this interval in an analogue for understanding the future role Antarctica, in particularly the WAIS, will have on global climate and sea level. Because of this, most studies have concentrated on the upper $600 \mathrm{~m}$ of the AND-1B core.

\section{Sedimentology}

In the upper $600 \mathrm{~m}$ of the AND-1B core (Figure 3) Naish et al. (2009a) identified repetitive sedimentary changes that were interpreted as cycles of glacial advance and retreat. The cycles alternate from warmer, ice-free diatomite facies to cold glacially derived diamictite facies. These cycles are bounded by unconformities attributed to erosion from grounded ice during the coldest period. By counting and dating the individual cycles, a $\sim 40$ kyr periodicity was able to be determined (Figure 3). Naish et al. (2009a) demonstrate that AND-1B is the first well-dated Antarctic climate record to directly sample the $\sim 40$ kyr oscillations in Earth's orbital obliquity, providing insight into the way variations in the Earth's orbital obliquity have affected Antarctic 
glaciation to date.

A thick marine diatomite unit lies between 438 and 376 mbsf, spanning $200 \mathrm{kyr}$ (between 3.6 and 3.4 Myr ago), and is believed to have been deposited during a time when average global temperatures were warmer than present (Naish et al., 2009a). This diatomite unit contains a very low abundance of sea-ice-associated diatoms, suggesting that sea surface and air temperatures may have been above freezing during the austral winter. Recent modeling (Pollard \& DeConto, 2009) suggests that the diatomites record the complete collapse of the WAIS from marine basal and surface melting.

McKay et al. (2009a) provide a detailed study of the stratigraphy of the AND-1B core (Figure 3). They expand on the work done by Krissek et al.(2007) and study the facies associations of $\sim 58$ orbitally controlled depositional sequences. They identified 3 characteristic depositional styles, or 'motifs'. Each motif is linked to a different glacial configuration that represent variation in the climate during deposition (Figure 3).

Motif 1 is dominated by subglacial diamictite with overlaying thin mudstones (ice-shelf deposits). It is also characterised by a lack of evidence of subglacial meltwater. Conditions are interpreted to be 'Polar' where an ice-shelf existed over the drill site during glacial minima and no open water conditions existed during the deposition of Motif 1 . Motif 1 style deposits are identified in the mid-Pliocene and then again in the Pleistocene.

Motif 2 is characterised by subglacial diamictite with overlying thin mudstones (glacial retreat) and diatom-bearing mudstone/diatomites (glacial minima). Limited amounts of subglacial meltwater are identified. Conditions are interpreted to be warmer than present "subpolar" to "polar". During the deposition of motif 2 the ice sheet is interpreted to be more dynamic that during motif 1 . Motif 2 is also split into two "sub-motifs" based on the content of terrigenous 
sediment during the glacial minima; $2 \mathrm{a}$ contains a minor terrigenous component whereas $2 \mathrm{~b}$ is characterised as terrigenous-bearing to terrigenous-rich. Motif 2 covers from the Early-Pliocene where it has the most meltwater influence to the Late-Pliocene where it has the least meltwater influence. The change in meltwater influence records the change from a "subpolar" glacial regime to a "polar" glacial regime.

Motif 3 is characterised by subglacial diamictite grading up into stratified diamictite-tomudstone successions. Thick mudstone units are deposited during the glacial minima with increased terrigenous input. Conditions are interpreted as "subpolar" with significant amounts of meltwater. Motif 3 occurs in the Late-Miocene.

\section{Provenance}

Talarico et al. (2010) examined the petrology of the sand fraction and of granule-to-cobblesized clasts in detail of the upper $400 \mathrm{~m}$ of the AND-1B core with the aim of identifying the sediment/clast provenance (Figure 3). They identify long and short-term compositional patterns and variations that help identify the dominant source areas for glacial debris and show the implications for ice dynamics models.

A significant change in diamictite provenance at $82.7 \mathrm{mbsf}$ coincides with a change in sedimentary cycle architecture (or "motifs") as identified by McKay et al. (2009). Above 82.7 mbsf (labeled Motif 1 in Figure 3), Talarico et al. (2010) note the sediment as having a higher abundance of Trans Antarctic Mountain debris (Beacon and Ferrar supergroup debris) sourced from the Skelton-Mulock glacier area. Below $82.7 \mathrm{mbsf}$ (Motif 2 dominated) sediment clasts were also sourced from the Skelton region but the main supply of debris was picked up from volcanic centers in the McMurdo Sound area. 
During glacial minima Talarico et al. (2010) suggested that ice rafted debris was sourced from Ross Island or the Koettlitz Glacier. A minor component of ice rafted debris comes from the Skelton and Mulock glacier area suggesting that the calving line of the Ross Ice Shelf must have retreated past the mouths of these two glaciers.

\section{Diatoms}

Sjunneskog et al. (2010) and Sjunneskog \& Winter (2010) examined diatoms from several intervals of the upper $600 \mathrm{~m}$ of the AND-1B core. The areas examined in detail were the midPliocene warm period (ca 3.6-3.4 Ma [ 450-390 mbsf]) and the late-Pliocene cooling (ca 2.92.0 Ma [ 180 mbsf]). Sjunneskog \& Winter provide an in depth study of the late-Pliocene cooling. They find that sea-ice assemblages which include Fragilariopsis curta which today make up between $20-80 \%$ of the modern assemblage found in McMurdo Sound also make up roughly $10 \%$ of the Pliocene assemblage, suggesting less annual sea-ice than present. In the LatePliocene interval they note Fragilariopsis curta makes up 3\% of the assemblage, occasionally reaching up to $20 \%$, indicating that significant sea-ice existed but at levels well below those recorded in the present day, suggesting that the climate of the time was still warmer than present. The warm water species they encounter in the core suggest sea surface temperatures of between 2 and $5^{\circ} \mathrm{C}$. They also note a low abundance of the cold water and sea-ice indicative species Eucampia antarctica. Open ocean species are also noted as being poorly represented in the assemblage.

They summarise that their findings suggest a reduced mid- and late-Pliocene sea-ice and increased sea surface temperatures and conclude that this suggests a reduction in Southern Ocean overturning. A distinct change observed in the diatom assemblage to cold water indicators at 2.58 Ma, around the same time as Greenland Ice Sheet development supports the 
hypothesis of a connection between and the initiation of northern and southern hemisphere

Polar conditions. However Sjunneskog \& Winter (2010) note the stepwise cooling trend over a time period rather than a single cooling event. 


\subsection{PALYNOLOGY METHODS}

\subsection{SAMPLE PREPARATION}

Samples for this study were selected from the AND-1B core at the Albert P. Crary Science and Engineering Center (CSEC) at McMurdo Station, Antarctica by the on-ice palynologist Michael Hannah. The selection was based on regular $10 \mathrm{~m}$ intervals, allowing for variation due to lithology. There was a preference for fine-grained material as this lithology is likely to contain higher concentrations of palynomorph. The samples chosen for this study are plotted against the lithological $\log$ in Figure 3, the precise depths of each sample are listed in Tables 1,2 and 3.

All samples were processed by Roger Tremain in the GNS laboratory, Lower Hutt, New Zealand, using a standard palynological technique: 10-20 g of sample was weighed then crushed. The sample was then treated in hot $50 \%$ hydrochloric acid to remove carbonates, followed by treatment in $50 \%$ hydrofluoric acid to remove silicates. The palynomorph content is unaltered by these acids. The resulting solution was treated in hot $10 \%$ hydrochloric acid to dissolve any fluorides present. Samples were then placed briefly in nitric acid followed by $5 \%$ ammonia solution to oxidize and dissolve humic organic matter. The remaining sample was floated with heavy liquid (with a specific gravity of 1.6 ) to separate the organic palynological fraction from residual mineral material and some coal fragments. The lighter material was then sieved and the 6 to 240 micron size organic fraction retained. This was then mounted onto glass microscope slides using glycerin jelly. Slides are stored at GNS Science, Lower Hutt, New Zealand. 


\subsection{MICROSCOPE AND CAMERA TECHNIQUE}

A Leica DMLB light microscope with $\times 20, \times 40$ and $\times 100$ magnification objectives was used to examine slides and document palynomorphs. A Leica DFC 280 microscope mounted camera was attached. The camera software (run through "Irfanview") used automatic exposure and white balance. Manual brightness was set and images were catalogued and saved, unedited, as JPEG files. Images of palynomorphs used for plates (See Plates 1-5) have undergone some cropping, rotation and minor brightness correction. No color alteration as been applied. The location of all palynomorphs photographed were recorded as England Finder coordinates and referenced to photograph catalogue numbers.

\subsection{SAMPLE COUNTING}

All slides from every sample examined were scanned completely and an absolute total count of all palynomorphs was made (Table 1). The abundance of palynomorph assemblages documented in this study is low overall. Specimens were often broken or obscured by inorganic fragments. When counting if a quarter or more of the palynomorph grain was recognizable it was included in the count. Data was entered into an Excel worksheet and grouped into genera and species.

Data was then converted from the raw count into two other formats i.e. percentages (Table 2) and grains per gram (Table 3). The grains-per gram figures were calculated by dividing the number of palynomorphs counted by the dry weight of the sediment. 


\subsection{SPECIES IDENTIFICATION}

Genera and species were identified largely by comparison to images from literature on dinoflagellates, prasinophyte alga, acritarchs, scolecodonts and full palynology studies. These included a range of published papers (see Appendix A), published theses and personal communication. Identified species were often cross-checked with other resources for clarification and then traced to their first taxonomic description (Appendix A). Because of the weathered nature of the reworked specimens, identification was often best approximated to genus rather than species.

\subsection{CONTAMINATION}

Several slides contained extremely low abundances of modern bisaccate pollen, easily identified by its color, excellent preservation and sometimes the preservation of the cytoplasm. These were presumed to be contaminants.

\subsection{GRAPHING AND GRAPHICS}

Raw count data, percentage data and grains-per-gram data were all separately entered into "Psimpoll" graphing software where they were converted from data into raw graphs. The graphs were imported into Adobe Illustrator graphics software where cosmetic changes were made before final graphs were stored and printed. 


\subsection{RESULTS, PALYNOLOGICAL OVERVIEW \& INTERPRETATIONS}

Figures 5,6 \& 7 illustrate the findings of the palynomorph analysis on the upper $600 \mathrm{~m}$ of the AND-1B core.

On the far left of Figures 5, $6 \& 7$ is a lithological log of the upper $600 \mathrm{~m}$ of the AND-1B core and the age interpretation of the core based on isotope analysis of volcanic deposits and magnetic polarity of sediments (Naish et al. 2009a). Adjacent to this are three graphs of the marine and terrestrial palynomorph distribution over the upper $600 \mathrm{~m}$ of the AND-1B core. The first graph, titled Palynomorph Assemblage (\%), shows the distribution of the 5 major palynomorph groups identified in the core: Dinoflagellates, acritarchs, prasinophyte algae, terrestrial palynomorphs and 'other' palynomorphs. The second graph separates the palynomorph assemblage into reworked and in situ groups: Reworked dinoflagellates, reworked acritarchs, reworked terrestrial palynomorphs, and in situ palynomorphs. The last palynomorph graph shows the abundance of palynomorphs throughout the AND-1B core.

To the right of this, on Figures $5 \& 6$, is a plot of the percent (Figure 5) and abundance (Figure 6) of each identified palynomorph, palynomorphs are grouped into the following categories: dinoflagellates, acritarchs, prasinophyte algae, terrestrial palynomorphs, and other palynomorphs (described in detail in 4.1). Figure 7 contains 3 columns summarising major events identified in the palynology, trends identified in the palynology, and an interpretation of the palynomorph assemblage. These figures are discussed in greater detail in the following chapters. 


\subsection{PALYNOMORPH ASSEMBLAGES}

Palynomorphs are the acid insoluble remains of, typically single-celled, terrestrial (spores and pollen), or marine (dinoflagellate cysts, acritarchs and algae) microfossils. Their organic composition (sporopollenin or chitin) is extremely inert which means they are highly resistant to decay and are usually well preserved in the fossil record. Marine palynomorphs are the focus of this study. The dominant groups are:

\section{Dinoflagellate Cysts}

Dinoflagellates are a group of freshwater and marine planktonic protists. Dinoflagellate cysts are the only preservable remains of dinoflagellates, and are left behind after the dormant zygotic stage of the dinoflagellate lifecycle (Tappan, 1980). Here they are simply referred to as dinoflagellate cysts and are separated into two groups; 'in situ'or 'reworked'.

- In situ dinoflagellate cysts: These are dinoflagellate cysts deposited contemporaneously with the enclosing sediment. Only two species of dinoflagellates are thought to be in situ in this study. The dominant form is referred to as 'Round Brown'. Although the dinoflagellate cyst cannot be identified, its morphological features (Appendix A) suggest it is a protoperidinioid dinoflagellate. It has been recorded in several studies of high latitude palynomorphs (Harland et al., 1998; Harland, 1989) and its excellent preservation and co-occurrence with other palynomorphs that are more easily identifiable as in situ also suggest that this dinoflagellate was deposited in situ.

The other species of dinoflagellate cyst considered to be in situ is an unknown species referred to the genus Eatonicysta. This species has very long and fragile processes supporting a delicate ectophragm, which is often not damaged. This excellent preservation strongly suggests in situ deposition. It also co-occurs with other in situ palynomorphs and rarely with 
reworked dinoflagellate cysts. However, this species should be treated with caution, as the specimens identified here are very similar to forms recorded from northern hemisphere rocks of Eocene age (Appendix A). There are several possible explanations for this: 1) Eatonicysta has a much larger age range than was previously understood(Wilson \& Clowes, 1980),2) The Eatonicysta recorded here has been delicately reworked from older sediments, although this seems unlikely, or 3) That this palynomorph is in fact not Eatonicysta and has been misidentified.

In situ dinoflagellate cysts are not present when there is floating ice cover at the drill site despite a thick water column (Mearns, Appendix B). Their occurrence in the core likely indicates that there was no ice cover at the drill site. It is also likely there was no permanent ice in the Ross embayment and environmental conditions were likely warmer than those observed today.

- Reworked dinoflagellate cysts: The reworked dinoflagellate cysts recorded here are all Eocene in age. They are often heavily weathered and fragmented. The entire assemblage are all elements of the well known endemic Eocene "Trans Antarctic Flora” (Levy \& Harwood, 2000; Wrenn \& Beckman, 1982; W renn \& Hart, 1988). Genera with processes such as Enneadocysta are often highly fragmented or are identified by a single remaining process alone. Several reworked dinoflagellate genera occur in extremely low abundance and have been grouped together, referred to as other Eocene dinoflagellate cysts for simplicity.

Reworked dinoflagellate cysts are deposited at the drill site during modern glacial configurations (Mearns, Appendix B), they are most likely eroded from older sediments by glacial erosion, entrained in the sub-ice sediment flow and deposited at the drill site. They are likely to dominate assemblages during colder periods during Antarctic ice expansion. 


\section{Acritarchs}

Acritarchs are microscopic organic remains of unclassified or unidentified biological origin. They include a wide range of forms. Although they are of unknown origin, many species are well documented with strong environmental affinities that are useful for environmental interpretations. Acritarchs are also separated into in situ and reworked groups.

- In situ acritarchs: The spherical acritarch Leiosphaeridia is considered to be the only in situ acritarch identified. Specimens are always well preserved, despite the delicate nature of their wall. It is commonly found in modern high latitude regions and in environments adjacent to ice shelf edges (Mudie, 1992). In this study specimens show no signs of weathering/reworking.

In situ acritarchs are not common when there is floating ice cover at the drill site despite a thick water column (Mearns, Appendix B). Their occurrence suggests that there was no ice cover at the drill site, it is also likely there was no permanent ice in the Ross embayment and environmental conditions were likely warmer than those observed today.

- Reworked acritarchs: Micrhystridium is the only reworked acritarch genus identified. Micrhystridium has a very long age range, first appearing in Precambrian and still found in modern oceans. In this study specimens appear to be heavily weathered and only occur in samples yielding the Eocene dinoflagellate cyst assemblage that is clearly reworked. In addition they do not appear to increase in abundance with increasing numbers of in situ palynomorphs, often occurring in samples with no in situ palynomorphs present.

Reworked acritarchs are deposited at the drill site during modern glacial configurations (Mearns, Appendix B), they are most likely eroded from older sediments by glacial erosion, entrained in the sub-ice sediment flow and deposited at the drill site. They are likely to dominate assemblages during colder periods during Antarctic ice expansion. 


\section{Prasinophyte Algae}

A single genus of prasinophyte algae, Cymatiosphaera, occurs in several samples throughout the core. It has a long age range (Mudie, 1992), first occuring in Precambrian sediments and is still found in modern high latitude environments where it is known to thrive in reduced salinity waters (Mudie, 1992; Prebble et al. 2006). It is well preserved and can confidently be identified as in situ.

In situ prasinophyte algae are not present when there is floating ice cover at the drill site despite a thick water column (Mearns, Appendix B). Their occurrence suggests that there was no ice cover at the drill site, it is also likely there was no permanent ice in the Ross embayment and environmental conditions were likely warmer than those observed today. Their occurrence also suggests reduced oceanic salinity (Mudie, 1992; Prebble et al. 2006)..

\section{Terrestrial Palynomorphs}

Several types of terrestrial palynomorphs were observed in samples throughout the core but their identification is outside of the scope of this study. They have however been counted and are represented in the assemblage charts. Their poor condition and discoloration suggest they were locally reworked from significantly older sediments.

\section{Other Palynomorphs}

Marine palynomorphs not identified as belonging to any of the above categories are referred to as 'other palynomorphs'. They include scolecodonts, microforaminiferal linings and unidentified palynomorphs. 
- Scolecodonts: Scolecodonts are the jaws of polychaete annelids. The jaws are easily preserved because they are made of chitin. They are also well preserved and occur with other in situ palynomorphs suggesting that they are also deposited in situ.

Scolecodonts are not identified in significant numbers when there is floating ice cover at the drill site despite a thick water column (Mearns, Appendix B). Their occurrence suggests that there was no ice cover at the drill site, it is also likely there was no permanent ice in the Ross embayment and environmental conditions were likely warmer than those observed today.

- Microforaminiferal linings: The microforaminiferal linings recovered in this study are mostly planispiral and their delicate structure is well preserved so they are considered to be in situ. Microforaminiferal linings are not common in sediments that were deposited when there is floating ice cover at the drill site despite a thick water column (Mearns, Appendix B). Their occurrence likely indicates that there was no ice cover at the drill site, it is also likely there was no permanent ice in the Ross embayment and environmental conditions were likely warmer than those observed today. 


\subsection{DIVERSITY AND ABUNDANCE}

Palynomorph grains vary in abundance ranging from 0 to 295 palynomorph grains per gram of sediment (GPG) per sample. Over 30 GPG were counted in more than half of the samples between 450 and $600 \mathrm{mbsf}$, and from $\sim 0$ to 150 mbsf most samples contain fewer than 10 GPG. Overall there is a general up-core decrease in marine palynomorph abundance (see abundance curve, Figure 5). The diversity of the marine palynomorphs in the upper $600 \mathrm{~m}$ of the AND- $1 \mathrm{~B}$ core is also highly variable (Figures $5 \& 6$ ).

The abundance of the reworked dinoflagellate cysts is very low (Figures $5 \& 6$ ); only two genera have counts of more than 3 GPG in a single sample. Other genera recorded counts as low as 2 GPG and often less than 1 GPG. The in situ dinoflagellate cyst Round Brown occurs in large quantities in a single sample at $441 \mathrm{mbsf}$ where over $234 \mathrm{GPG}$ were counted. The sphaeromorph acritarch Leiosphaeridia dominates the acritarch group and regularly yields counts of more than 20 GPG. It peaks in a sample with 78 GPG counted (598 mbsf).

Microforaminiferal linings have a relatively high abundance in the samples that they occur in, averaging more than 10 GPG and peaking with nearly 62 GPG in a single sample ( $598 \mathrm{mbsf}$ ). The overall diversity of marine palynomorphs is low (Figures $5 \& 6$ ), typical of cold Antarctic assemblages (Hannah et al., 2000; Hannah et al., 1998; Prebble et al., 2006). Only 2 dinoflagellate genera are identified as in situ; Eatonicysta and Round Brown. The remaining dinoflagellates are reworked (see Appendix A for a complete taxonomic list).

The diversity of acritarchs is low with only two genera identified; Leiosphaeridia and Micrhystridium. Only a single prasinophyte algae was identified; Cymatiosphaera. The terrestrial palynomorphs were counted but not identified in this study. Terrestrial assemblages are a mix of 
heavily weathered, reworked older material and younger, better-preserved material.

\subsection{LONG TERM TRENDS}

Changes in the palynomorph assemblage and abundance, along with the interpretations that can be made about them are observed on a large, core length scale, and a small, meter-length scale (Figures 5,6\&7). Large scale trends are outlined and interpreted below, small scale trends are discussed in Section 4.4

Large scale/core length trends: Starting at the core base and working upward, two trends are clear in the marine record: 1) A change in the composition of the marine palynomorph assemblage and 2) changes in overall abundance (Figures 5, $6 \& 7$ ):

1) Assemblage composition. The palynomorph assemblage is comprises of close to $100 \%$ in situ palynomorphs at the base of the interval studied ( $600 \mathrm{mbsf})$ and close to $100 \%$ reworked palynomorphs at the core top ( $20 \mathrm{mbsf}$ ), with the major change occurring around $180 \mathrm{mbsf}$. The shift between the two states may be gradual on the centimetre scale but is instantaneous on the metre scale. Below $180 \mathrm{mbsf}$, there are fluctuations in the percentage of reworked palynomorphs in the assemblage and this reworked fraction is dominated by reworked terrestrial palynomorphs. But in most samples below this depth, the assemblage is in general $>70 \%$ in situ marine palynomorphs. Above $180 \mathrm{mbsf}$, this compositional trend is reversed and most samples contain $>70 \%$ reworked palynomorphs.

2) Overall Abundance. The abundance of in situ palynomorphs shifts from nearly 150 GPG at the core base to less than 0.4 GPG at the core top. The shift from high-to-low abundance is not 
as instantaneous as the shift in assemblage composition, but fluctuates significantly over the entire core length, but a major, permanent change in abundance is seen at $180 \mathrm{mbsf}$. Below 330 mbsf, samples average 48 GPG, between $330 \mathrm{mbsf}$ and $180 \mathrm{mbsf}$ samples average $35 \mathrm{GPG}$, and above 180 mbsf samples average 9 GPG. Fluctuations can be as large as 294 GPG between samples, as seen between $451 \& 441 \mathrm{mbsf}$.

Interpretation: The change in assemblage between in situ and reworked palynomorphs acts as a paleoenvironmental change indicator (Figure 7). Mearns (Appendix B) showed that it is unlikely that any marine palynomorphs inhabit the modern water column $(920+m$ deep) with a permanent ice shelf present $(70+m$ thick). Harland et al. (1998) also demonstrate that surface sediments greatly reduced palynomorph abundances in areas that experience seasonal sea-ice due to the suppression of light energy to phytoplankton. This evidence suggests that a record of in situ palynomorphs in the AND-1B core is a good indicator of non-permanent ice or ice-free conditions at the drill site.

Recorded increases of in situ palynomorph abundance represent increased productivity that reflects changes in the environment (Harland, 1998). The highest in situ palynomorph abundances are recorded at the core base and at around $440 \mathrm{mbsf}$ (within a thick diatomite), suggesting that these are the more productive intervals. They are interpreted as being the periods of significantly warmer paleoenvironmental conditions.

Fluctuations in the in situ/reworked palynomorph assemblage below $180 \mathrm{mbsf}$ represent variability in the environmental conditions at the time of deposition. Overall in situ palynomorphs dominate, therefore this interval is interpreted as being more productive and likely warmer than modern conditions where in situ palynomorphs are extremely rare (Mearns, Appendix B). Fluctuation in reworked palynomorphs does not appear to be controlled by 
lithology (Figures 5, $6 \& 7$ ). This suggests that palynomorphs are more sensitive to changes in temperature/oceanic conditions than the lithology.

Fluctuations in reworked palynomorph content not only reflect corresponding fluctuations in the paleoenvironmental conditions, but also changes in ice dynamics because a colder climate in Antarctica is likely to lead to an expansion in Antarctic ice volume. Increased ice volume increases glacial flow, leading to increased erosion and more reworked palynomorphs being liberated.

An increase in sediment erosion results in a greater abundance of the reworked palynomorphs being liberated from their source rock, but also a larger amount of reworked sediment being deposited. Therefore an increase in sediment erosion on the continent is not likely to be reflected in the abundance of reworked palynomorphs. As a result of this changes in the assemblage of reworked palynomorphs, rather than changes in abundance, are likely to reflect variability in glacial dynamics and paleoenvironment.

Above $180 \mathrm{mbsf}$ the palynomorph assemblage is dominated by reworked palynomorphs. The major change at 180 mbsf indicates a very rapid and significant change in the Antarctic paleoenvironment. Extremely low abundances of in situ palynomorphs suggest less productivity, and their complete absence from some samples suggests permanent ice cover at the drill site.

The sudden appearance of reworked marine palynomorphs at $180 \mathrm{mbsf}$ also indicates a new region of source material being eroded and suggests a shift in Antarctic ice dynamics. This may be described by the shifting of the ice grounding line, higher rocks being eroded in glacial valleys as glaciers increase in volume, glaciers penetrating new valleys, or more intense erosion from ice sourced in southern TAM outlet glaciers.

Summary: Overall there is an up-core trend toward a cooler environment (Figure 7). Several fluctuations can be observed below 180 mbsf where conditions shift between a warmer and 
more productive environment to cooler periods with reduced biotic productivity. The major change in palynomorph assemblage and abundance at $180 \mathrm{mbsf}$ represents a significant environmental change to a much cooler environment, with long periods of permanent ice cover at the AND-1B drill site and a change in local ice dynamics.

The observed trend toward conditions that are similar to today's conditions at the drill site, is identified by both Naish et al (2009a) and Pollard and DeConto (2009), which is consistent with the hypothesis.

\subsection{SHORT TERM TRENDS}

Using changes in the abundance and diversity of marine palynomorphs the core can be divided into 6 palynomorph units (Figures $5 \& 6$ ). These units are thought to reflect changes in the depositional environment (Figure 7):

PALYNOMORPH UNIT 1 - Early-Pliocene, $~ 5.0$ - 4.6 Ma ( 600 to $459 \mathrm{mbsf}$ )

Unit 1 has a persistently high but variable palynomorph abundance, with most samples containing more than 30 GPG (Figures $5 \& 6$ ). The sample from near the base of the core $(598.0$ mbsf) contains 148 GPG. Roughly half of these are acritarchs (Leiosphaeridia) and the other half are microforaminiferal linings. Apart from a significant dip in acritarch numbers (predominantly Leiosphaeridia)at 578.2 mbsf these palynomorphs represent the majority (often well above $85 \%$ ) of the palynomorph content over this entire unit until their rapid decline between 460.7 and 451.2 mbsf.

This decline in Leiosphaeridia numbers coincides with a major change in lithology; below 459 
mbsf Naish et al. (2009a) show a relatively continuous package of diamictite/diatomite sedimentary cycles (Figure 3). Above $459 \mathrm{mbsf}$ is a $\sim 60 \mathrm{~m}$ thick marine diatomite. It is over this change from the cyclic sedimentary package to the thick diatomite package that the dominance of the Leiosphaeridia ceases.

Microforaminiferal linings peak in abundance in the oldest sample (598.0 mbsf). They are almost completely absent in the rest of the unit. There is a moderate presence of terrestrial palynomorphs throughout, with each sample containing $\sim 1$ or more GPG. This terrestrial flora makes up a low percentage of palynomorph assemblages from this unit, generally no more than $20 \%$.

An increase in dinoflagellate cysts, in particular the reworked Eocene species, between 580 and $460 \mathrm{mbsf}$ raises the diversity in this unit, however their overall abundance remains extremely low. Members of the acritarch genus Micrhystridium are present but in low abundance. Round Brown is the only dinoflagellate that shows a significant abundance over this interval, peaking at 32 GPG in a sample at $572.2 \mathrm{mbsf}$ ( $36 \%$ of the palynomorphs from this sample).

The prasinophyte alga Cymatiosphaera is present in two samples (526.4 and $493.8 \mathrm{mbsf}$ ) although in very low abundances (.07 and 1.46 GPG respectively).

Interpretation: The relatively high palynomorph abundances and a very high percentage of in situ specimens in this unit suggest that it was deposited during a time when marine conditions at the drill site were warmer with less ice cover, and more productive than the conditions observed at the site today (Figure 7) (Mearns, Appendix B).Leiosphaeridia dominates most of the assemblage from this unit, often making up $>80 \%$ of the total.

Coinciding with palynomorph Unit 1 Naish et al. (2009a) recorded a period of relatively continuous sediment deposition that is $265 \mathrm{kyr}$ in length and contains 6 obliquity cycles ( 40 kyr). Therefore Palynomorph Unit 1 can be considered a relatively continuous unit (i.e. few to 
no periods of unrecorded time) with relatively steady ice-proximal/seasonal-ice conditions.

Toward the base of Unit 1 ( $578.2 \mathrm{mbsf})$ there is a decrease in the number and percentage of Leiosphaeridia that coincides with a diatomite unit (see lithological log, Figures 5, $6 \& 7$ ). This sample also contains an increase in the percentage of microforaminiferal linings and the dinoflagellate cyst Round Brown, indicative of ice-free, highly productive conditions (Section 4.1). This brief period is likely the warmest recorded period of Unit 1 with ice-free, productive waters at the drill site.

There are two significant Leiosphaeridia peaks in this unit; at 558.9 mbsf where 37 GPG were identified and at $493.8 \mathrm{mbsf}$ where $75 \mathrm{GPG}$ are recorded. What is most noticeable about these peaks is that at both, reworked Eocene dinoflagellate cysts and reworked Micrhystridium species are also recorded. The number of reworked terrestrial individuals at these samples is also elevated relative to adjacent samples. These changes in assemblage suggest increased proximal ice and increased sediment erosion, the result of cooler temperatures. The appearance of the Eocene assemblage is most likely the result of a shift in ice dynamics due to cooling. This is discussed in greater detail in Unit 6.

Summary: During the deposition of Unit 1, warmer temperatures are likely to have reduced ice cover to semi permanent/seasonal ice cover. Conditions temporarily (10 kyr scale at $578 \mathrm{mbsf}$, Figure 7) became even warmer and ice-free at the base of this unit indicated by reduced Leiosphaeridia abundance and increased abundance of microforaminiferal linings \& Round Brown dinoflagellate cysts (Figure 7). Lithological evidence, in the form of thick diatomite deposits, supports the notion of warmer, ice-free conditions at the unit base. Ice volume on Antarctica is likely to be reduced compared to the modern configuration, with the possibility of complete WAIS collapses. There is however some short-lived periods of significant cooling, as indicated by increases in reworked palynomorph abundances and the appearance of reworked 
Eocene palynomorphs $(559,511 \& 494 \mathrm{mbsf})$.

PALYNOMORPH UNIT 2 - Mid-Pliocene, $4.6-3.4 \mathrm{Ma}$ ( 458 to $390 \mathrm{mbsf}$ )

This is a relatively thin palynomorph unit representing only about $68 \mathrm{~m}$ of core. The total palynomorph abundance over Unit 2 is extremely variable with counts ranging from a total of 1 GPG in a single sample (451.2 mbsf) to 295 GPG in the sample immediately above (441.1 mbsf) (Figures 4 \& 5). Unit 2 is characterised by the persistent low percentages of Leiosphaeridia generally making up no more than $20 \%$ of the assemblages. Paralleling the drop in percent and abundance of Leiosphaeridia present, there is a significant increase in the percent and abundance of microforaminiferal linings and scolecodonts.

Eocene dinoflagellate cysts are largely absent from the entire unit. The in situ dinoflagellate cyst Round Brown makes up the majority $(80 \%)$ of an abundance spike in marine palynomorphs at 441.1 mbsf. The prasinophyte alga Cymatiosphaera is present in very low abundance in two samples in this unit (taken at $419.0 \& 411.9 \mathrm{mbsf}$ ). This unit coincides with the diatomite unit observed in the lithological $\log$ (between $460 \& 380 \mathrm{mbsf}$, Figures 5 \& 6). Microforaminiferal linings and scolecodonts largely dominate the remaining samples in this unit.

Interpretation: Palynomorph Unit 2 is marked by a dramatic change in the palynomorph assemblage compared to Unit 1 , and also coincides with a large ( $\sim 60 \mathrm{~m})$ marine diatomite unit (Figure 7). The diatomite unit suggests that the drill site was ice-free during deposition and remained this way for as much as $1.2 \mathrm{Ma}$. Ice-free conditions at the drill site are indicated in the palynomorph assemblage by an overall low abundance of Leiosphaeridia. Supporting this, and also suggesting that the marine environment was productive for marine palynomorphs, is the increased abundance of microforaminiferal linings, Round Brown dinoflagellate cysts, and scolecodonts. 
Naish et al. (2009a) identified 4 or 5 main orbital cycles in the diatomite by examining the distribution of $>2 \mathrm{~mm}$ iceberg-rafted debris (IBRD). The resolution of the IBRD study is much finer than of this study so these cycles are not identified or represented in the distribution of palynomorphs over this interval.

Studies of modern polychaetes (of which, scolecodonts are the fossil remains) from the South Shetland Islands (Sicinski and Janowska, 1993) demonstrate that polychaete species composition, richness and diversity vary with depth but also vary greatly with sediment type, and higher abundances are recorded in soft, sand-to-silt sediments. Further study by Gambi et al. (1997) in the Terra Nova Bay in the Ross Sea, highlighted that polychaete population density and diversity were clearly related to the degree of physical disturbance and habitat complexity. Because water depth is a major control on physical disturbance (i.e. physical disturbance decreases with increasing depth) it is suggested that polychaete assemblages are depth dependent. Scolecodonts appear in samples throughout every palynomorph unit but peak in numbers in Unit 2. At 419.0 mbsf, 5 GPG are present in a single sample and in the following sample at 412.0 mbsf numbers peak at 12 GPG.

The scolecodonts have not been separated into species or genera for this study but if further analysis were to be carried out on the scolecodont assemblage and correlations made to other high latitude assemblages (such as Gambi et al., 1997; Sicinski \& Janowska, 1993), they may provide a proxy for water depth at the AND-1B drill site during deposition.

The near absence of reworked material within this unit $(\leq 0.7 \mathrm{GPG}$ of reworked terrestrial palynomorphs per sample and no recorded reworked dinoflagellate cysts) supports the suggestion of an ice-free environment at the drill site during deposition of Unit 2.

Summary: The near total absence of any reworked palynomorphs plus the high abundance of microforaminiferal linings, scolecodonts and Round Brown dinoflagellate cysts, indicate very 
low/no ice cover and possibly warmer, more productive waters than Unit 1. There is a slight cooling noted in the sample from $441 \mathrm{mbsf}$, identified by an increase in Leiosphaeridia (Figure 7).

PALYNOMORPH UNIT 3 - Mid-Pliocene, 3.4 - 3.2 Ma ( 390 to $288 \mathrm{mbsf})$

Palynomorph abundance throughout Unit 3 is relatively low (Figures $5 \& 6$ ). Most samples contain $15-30+$ GPG with a single sample (290.3 mbsf) containing 192 GPG. The termination of palynomorph Unit 2 and the start of Unit 3 is marked by the rapid reduction in the percentage of Microforaminiferal linings and Scolecodonts, and the resurgence in numbers of Leiosphaeridia.

Throughout this unit, assemblages dominated by round brown and microforaminiferal linings (considered to represent a warmer, more productive environment) alternate with assemblages dominated by Leiosphaeridia and terrestrial palynomorphs (considered to represent a cooler, less productive environment)(Figure 8). The cyclical pattern of palynomorph variation observed in this unit does not correspond to any of the cyclic variation observed in the lithology (Figure 8); both extremes of the cyclical pattern are observed in the diatomite unit ( $386.8 \& 379.2 \mathrm{mbsf})$, the mudstone/sandstone unit (369.5,347.6 and $321.2 \mathrm{mbsf})$ and the diamictite unit (343.0, $328.8,306.5$ and $300.4 \mathrm{mbsf})$. 


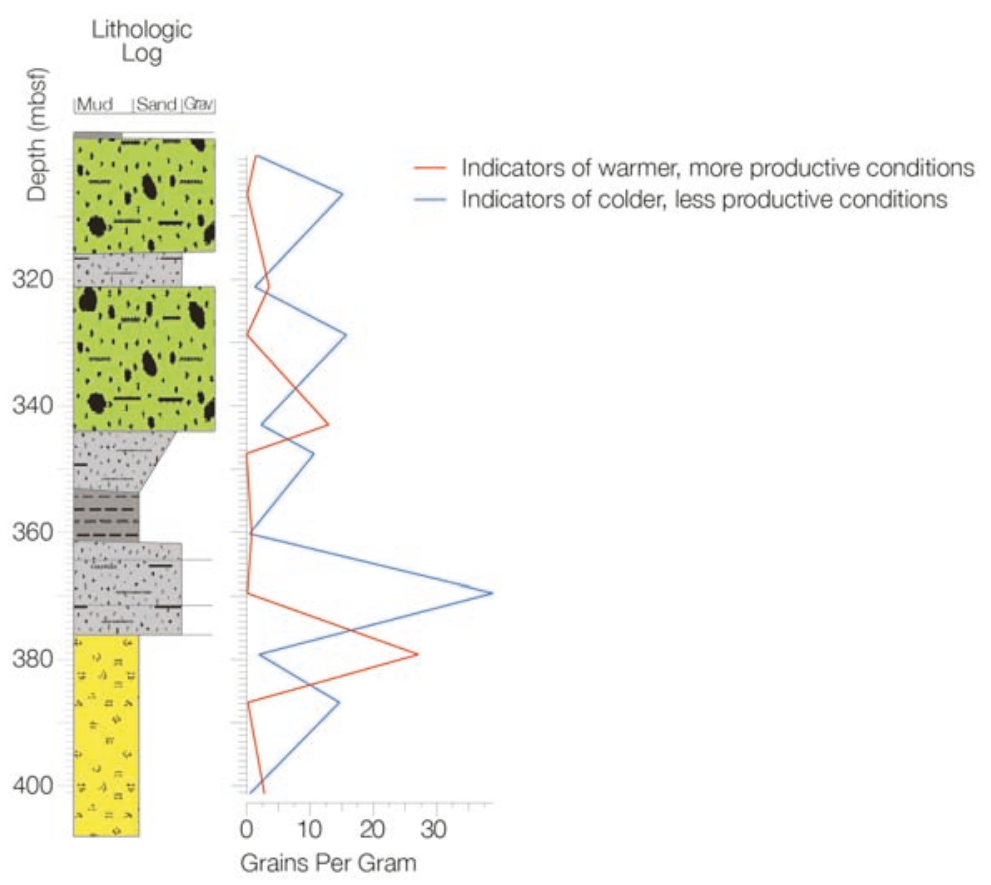

FIGURE 08 - Diagram showing the anti-phase relationship between the palynomorphs that indicate a cooler, less productive environment (largely made up of: Leiospheridia \& terrestrial), and those that indicate a warmer, more productive and likely ice-free environment (largely made up of: microforaminiferal linings \& Round Brown). No strong relationship between palynomorph assemblage and lithology is demonstrated over this interval.

Interpretation: The base of Unit 3 is marked by an increase in the abundance of Leiosphaeridia and reworked terrestrial palynomorphs, throughout this unit there is also a reduction in the abundance of microforaminiferal linings, and the near complete disappearance of scolecodonts. All of these are clear indicators of reduced productivity, increased reworking, and the presence of seasonal/proximal ice (Figure 7).

Assemblages throughout this unit dominated by Leiospheridia and reworked terrestrial palynomorphs suggest cooler environmental conditions with significantly increased seasonal/temporary ice in the Ross Embayment (Section 4.1). Assemblages dominated by round brown cysts and microforaminiferal linings suggest warmer environmental conditions and possibly ice free conditions within the Ross embayment (Section 4.1). Alternations between these two palynomorph assemblages persist throughout this unit suggesting that although the 
paleoenvironmental conditions are warmer than modern, the high latitude climate was variable.

The alternations between palynomorphs indicating a warmer, more productive environment and palynomorphs indicative of a colder, less productive environment do not compare well with lithological changes (Figure 8). Diamictites are indicative of glacial environments that are cooler and less productive but increases in the abundance of palynomorphs that indicate a warmer, more productive environment are observed in the middle of diamictites. The palynomorphs that appear to be mismatched with the lithology they are encapsulated in are likely recording brief warming periods that did not last long enough for a change in lithology to take place. The reverse may also be the case for increases in palynomorphs that indicate colder, less productive environments, recovered from diatomites. These discrepancies between lithology and palynomorph assemblage demonstrate that the palynomorph record is an accessible, sensitive indicator of the paleoenvironment that can reveal minor changes in environmental conditions. A much higher resolution analysis of the palynomorph record would reveal a detailed history of the highly dynamic paleoenvironment.

Summary: Unit 3 contains alternations between warmer, reduced ice periods with increased productivity, and cooler, increased ice periods of reduced productivity (Figure 8). These two climatic end members do not appear to be separated by a large temperature gap and this state is steady for the entire unit. Fluctuating temperatures are likely to be warmer than the modern McMurdo environment.

PALYNOMORPH UNIT 4 - Mid- to Late-Pliocene, 3.2 - 3.0 Ma ( 287 to $228 \mathrm{mbsf}$ ) Samples from this unit yielded only low numbers of palynomorphs, the most abundant sample containing 27 GPG (at 269 mbsf) (Figures 5 \& 6). Apart from a single Enneadocysta sp. specimen (253.0 mbsf) and a single Vozzhennikovia apertura specimen (243.8 mbsf) this unit contains no 
dinoflagellate cysts. The lack of Round Brown dinoflagellate cysts, which are constantly present throughout all older units, is particularly notable. The alternations between an assemblage dominated by Leiospheridia and terrestrial palynomorphs and an assemblage dominated by microforaminiferal linings (initially recorded in Unit 3) persist throughout this unit (although more difficult to recognise). Terrestrial palynomorphs peak in this unit with 11 GPG counted at $269.0 \mathrm{mbsf}$ (50\% of the total assemblage), the highest record of terrestrial palynomorphs from a single sample.

Interpretation: Unit 4 is very similar to Unit 3, but is distinguished by having a total absence of Round Brown dinoflagellate cysts, a reduction in the number of microforaminiferal linings, and an increase in the number of terrestrial palynomorphs found in several samples. These assemblage changes suggest colder conditions and more ice present than during the deposition of Unit 3 (Figure 7). The cyclic nature of the composition, as mentioned above in Unit 3, is much harder to distinguish in this unit, suggesting a more stable environment.

Summary: Unit 4 reflects a colder and more stable environment than Unit 3, with a less pronounced cyclicity (Figure 7). Temperatures are still likely warmer than modern, and icecover is not permanent at the drill site.

PALYNOMORPH UNIT 5 - Late-Pliocene, 3.0 - 2.6 Ma ( 227 to $184 \mathrm{mbsf}$ ) This unit is the thinnest recognized in the core, spanning a total of $43 \mathrm{~m}$ (Figures $5 \& 6$ ). It is characterised by an increase in total palynomorph abundance. Two samples within this unit contain over 100 GPG (at 224 and $201 \mathrm{mbsf}$ ) and the rest contain between 7 and 49 GPG per sample. The dinoflagellate Round Brown reappears in high quantities and the acritarch Micrhystridium reappears after a near total absence since Unit 1 . The sample at the base of this unit (224.4 mbsf) yielded high numbers of the prasinophyte alga Cymatiosphaera (37 GPG). 
This is one of six samples that contain this prasinophyte alga, however the five other sample depths all contain a maximum of 1.46 GPG. The variability in abundance of Leiospheridia, terrestrial palynomorphs and microforaminiferal linings, described in Unit 3 continues through this unit.

Interpretation: The first sample of this unit $(224.4 \mathrm{mbsf})$ records the abundance spike that characterises this unit and contains 40 Round Brown and 37 Cymatiosphaera GPG. Only 0.4 Leiospheridia and 0.04 terrestrial GPG are identified in this sample. There is also a moderate increase in the number of microforaminiferal linings (2.5 GPG) and scolecodonts (0.5 GPG) (Figures $5 \& 6$ ). All of these observations can be interpreted as a sudden warming, a reduction in ice volume and an increase in the productivity in the ocean surrounding the drill site (Figure 7). Cymatiosphaera is a prasinophyte alga and recent studies have shown that this particulargenus may have a preference for waters with reduced salinity (Mudie, 1992; Prebble et al., 2006). If this interpretation is correct then the high numbers of Cymatiosphaera at $224.4 \mathrm{mbsf}$ may indicate an influx of fresh water, possibly the result of increased meltwater entering the system. The lithological evidence supports this suggestion as this sample occurs at the base of a diatomite unit immediately after a diamictite unit - which is taken as representing the change from glacial to ice free conditions.

The second major peak in palynomorph abundance within Unit 5 also occurs immediately after a diamictite-diatomite boundary (201.3 mbsf). Round brown abundance is high (56 GPG), reworked terrestrial palynomorph abundance is low (0.34 GPG) and a relatively low abundance of Leiospheridia is also present (2.6 GPG). There are no Cymatiosphaera specimens recorded in this sample but there is a much greater abundance of microforaminiferal linings ( 30 GPG) than recorded in the abundance spike at $224.4 \mathrm{mbsf}$.

These observations can be explained by timing. If the Cymatiosphaera species identified is in fact 
recording a fresh water influx it could be (in sample $224.4 \mathrm{mbsf}$ ) representing a short-lived meltwater influx and period of reduced salinity, acting almost like a pioneer species, and as soon as the meltwater influx slows and salinity increases, the Cymatiosphaera population migrates or becomes locally extinct. Once regular ocean salinity is re-established, other marine biota that may be unable to tolerate reductions in salinity will begin to re-inhabit the area. In the abundance peak at 224.4 mbsf microforaminiferal lining concentrations are 2.5 GPG and Cymatiosphaera concentrations are 37 GPG. Where as the abundance peak at $201.3 \mathrm{mbsf}$ contains no Cymatiosphaera specimens but microforaminiferal lining concentrations are a relatively high 30 GPG. This suggests that these particular foraminifera might be unable to inhabit the reduced salinity waters that Cymatiosphaera thrive in.

In both of these samples (224.4 \& $201.3 \mathrm{mbsf}$ ), Round Brown occurs in high abundances suggesting that it is tolerant to a wide range of salinity levels.

Summary: The return of the Round Brown dinoflagellate cyst in this unit indicates that although sedimentation style is similar to Unit 4 (see lithological log, Figures $5 \& 6$ ), Unit 5 is likely to have been deposited during warmer temperatures (Figure 7). The dramatic increase in prasinophyte algae likely represents a period of reduced salinity caused by a meltwater event.

PALYNOMORPH UNIT 6 - Latest-Pliocene through Pleistocene, 2.6 Ma and younger ( 183 to $24 \mathrm{mbsf}$ )

The youngest palynomorph unit is distinguished from Unit 5 by a reduced total abundance of marine and terrestrial palynomorphs and a significant shift in the composition of the assemblage to one dominated by reworked palynomorphs. 0.33 GPG of Round Brown appear in the first sample (181.6 mbsf) but are otherwise totally absent from this unit. Apart from a low abundance in the first few samples of this unit $(181.6,170.4$ and $169.6 \mathrm{mbsf})$ microforaminiferal 
linings also become absent from the unit. Leiospheridia numbers drop, typically occurring in concentrations of no more than 1 GPG per sample (in previous samples they typically peak at $10-20+G P G)$.

The major signal in Unit 6 is the consistent appearance of a variety of reworked Eocene dinoflagellate cysts and the acritarch Micrhystridium sp. Throughout this unit Micrhystridium sp. often makes up $30 \%$ or more of the total palynomorph assemblage.

Matching the abundance pattern of reworked Eocene dinoflagellate cysts, Micrhystridium occurs in moderate abundance in samples from 559.0 and $502.7 \mathrm{mbsf}$ ( 1 and 0.79 GPG respectively). Also matching the abundance pattern of Eocene dinoflagellate cysts, Micrhystridium is not recorded in Units 2,3, and 4 (Figure 6). This strongly suggests that Micrhystridium is present as a result of reworking.

The Eocene dinoflagellate cysts make up around $20-30 \%$ (Figures 5,6\&7) of the assemblage of this unit. Deflandrea, Enneadocysta, Spinidium and Vozzhennikovia in roughly equal parts dominate the Eocene genera. There is also a minor $(<10 \%)$ component of other Eocene dinoflagellate cysts including: Alterbidinium sp, Cribroperidinium giuseppi, Eocladopyxis peniculata, Hystrichosphaeridium sp, Impagidinium victorianum, Lejeunecysta byalina, Operculodinum bergmannii, Spiniferites ramosus, Thalassiphora pelagica and Turbiosphaerafilosa.

Interpretation: The most notable feature of assemblages from this unit is the absence of in situ palynomorphs, which dominates all assemblages from this unit. The change to assemblages dominated by reworked palynomorphs is sudden, suggesting a rapid increase in ice-cover at the drill site and colder temperatures inhibiting productivity. In situ palynomorphs that are identified in this unit are primarily Leiospheridia, which also indicates colder water with nearby permanent/seasonal ice (Mudie, 1992).

Because the palynomorph assemblage throughout Unit 6 often contains more than $80 \%$ 
reworked material, the deposition of this unit is interpreted to be during the coldest period of the core. At several locations in Unit 6 (152.0, $40.7 \& 24.34$ mbsf), samples contain $100 \%$ reworked material. This is interpreted to be the result of ice grounding at the drill site, where sub-ice deposition occurs and there is no accommodation space between the ice and sea floor for palynomorphs to inhabit or even be swept in by currents and deposited in the sediment. This change to a climate colder than modern and an ice volume greater than modern is supported by Naish et al. (2009a) and Pollard \& DeConto (2009) in their recent studies on the effect of Antarctica on global oceans and temperatures.

The appearance of the Eocene flora alongside reworked terrestrial palynomorphs (which persisted throughout all palynomorph units) is best explained by changes in the source of reworked sediments. Either a change of source material or the addition of other source materials containing Eocene dinoflagellate cysts. Antarctic ice volume is likely to be controlling which source material is being reworked. Unit 6 represents the coldest period studied and the result of this is a forced change in ice dynamics and subsequently a change in the provenance of reworked material.

Summary: Unit 6 is the coldest period identified in the upper $600 \mathrm{~m}$ of the core and represents a major change in Antarctic ice volume and ice dynamics (Figure 7). Ice volume on the continent is likely to be greater than the modern ice volume. 


\subsection{INTEGRATION AND DISCUSSION}

Figure 10 integrates the findings made here with other studies conducted on the AND-1B core, regional Antarctic studies and global climate studies.

On the far left of figure 10 is a lithological log of the upper $600 \mathrm{~m}$ of the AND-1B core and the age interpretation of the core based on isotope analysis of volcanic deposits and magnetic polarity of sediments (Naish et al. 2009a). Adjacent to this are three graphs of the marine and terrestrial palynomorph distribution over the upper $600 \mathrm{~m}$ of the AND-1B core as shown in figures 5, 6,7 \&9. The first graph, titled Palynomorph Assemblage (\%), shows the distribution of the 5 major palynomorph groups identified in the core: Dinoflagellates, acritarchs, prasinophyte algae, terrestrial palynomorphs and 'other' palynomorphs. The second graph separates the palynomorph assemblage into reworked and in situ groups: Reworked dinoflagellates, reworked acritarchs, reworked terrestrial palynomorphs, and in situ palynomorphs. The last palynomorph graph shows the abundance of palynomorphs throughout the AND-1B core.

The centre of the diagram is a synthesis of Antarctic and global studies during the PliocenePleistocene period plotted against the lithological log and palynomorph graphs. The synthesis is broken into 4 separate columns: 1) ANDRILL MIS. This column summarises the major trends and events identified from the ANDRILL MIS project. It includes results from two lithological studies (McKay et al., 2009; Naish et al.,2009a), a clast provenance study (Talarico et al., 2010), two diatom studies (Sjunneskog \& Winter, 2010; Sjunneskoget al., 2010) and some results palynological study presented here. 2) Antarctic Region. This summarises the wealth of studies undertaken in areas around Antarctica that cover the Plio-Pleistocene period.3) Antarctic Modeling. Presented in this column is a summary of the modeled Antarctic cryosphere (Pollard \&DeConto, 2009).4) Global Climate. This column summarises the global climate throughout 
the Plio-Pleistocene.

On the far right of Figure 10 is an 'interpretation'. This section summarises all of the studies and their findings on Antarctic and global climate during several key intervals throughout the PlioPleistocene, and inferences about global climate and the Antarctic cryosphere are made. The following chapter is based on the observations and interpretations made from Figure 10.

\subsection{SYNTHESIS OF ANTARCTIC AND GLOBAL CLIMATE STUDIES}

Early-Pliocene ( 5.0 - 4.6 Ma, Palynomorph Unit 1)

The marine and terrestrial palynology of the early-Pliocene period (Palynomorph Unit 1, see Section 4.4) is suggestive of a variable but warmer than modern environment. High marine palynomorph abundances indicate productive oceans at the drill site, but the dominance of Leiospheridia in most samples indicates the periodic presence of ice near the drill site. Higher abundances of marine palynomorphs occur toward the base of this unit and decrease up-core with a concomitant up-core increase in Leiospheridia (indicative of proximal ice), suggesting a slight up-core cooling trend during the early-Pliocene. In a study of the sediments of the upper 600 meters of the AND-1B core, Naish et al. (2009a) infer a highly variable ice-sheet in the early-Pliocene that oscillated between a subglacial and open-marine state on a $40 \mathrm{kyr}$ scale.

Seismic studies (Cooper et al. 2009; Haywood et al. 2009) indicate that ice-grounding events occurred on the Ross Sea shelf and western Antarctic Peninsula shelf during the Early-Pliocene. Following these earlier events, seismic analysis revealed that the locus of sediment deposition in areas surrounding Antarctica was shifting toward the continental slope; a sign of increased glacial activity. 
Antarctic modeling(Pollard \& DeConto, 2009) predicts a significantly smaller than modern WAIS in the early-Pliocene and suggests that open-ocean conditions dominated the AND-1B site during the early- to mid-Pliocene ( $\sim 5$ to 3 Myr ago).

Global climate records and reconstructions indicate that during the early- to mid-Pliocene, atmospheric $\mathrm{CO}_{2}$ concentrations were $\sim 400$ ppm (Raymo et al. 1996; Tipple et al. 2010); global temperatures were $\sim 3^{\circ} \mathrm{C}$ higher than modern (Dowsett et al. 1994); and eustatic sealevel was $\sim 25$ meters higher than modern (Miller et al. in press).

Interpretation: The early-Pliocene exhibited a significantly warmer than modern global climate and eustatic sea level was $\sim 25 \mathrm{~m}$ higher, a result of reduced polar ice volume. In the Antarctic the WAIS was beginning to form with some ice expansions during colder periods, where the icegrounding line progressed out along the Ross Sea shelf and other surrounding shelves. Variability in ice-volume is evident from the paleontology and sedimentology of the AND-1B core and seismic studies from the Ross Sea and western Antarctic Peninsula. The variability is likely controlled by $\sim 40 \mathrm{kyr}$ cycles in the Earth's axial tilt (obliquity), altering solar radiation to the Earth's poles. These warm and variable conditions persisted until a significantly warmer midPliocene.

Mid-Pliocene ( 4.6 - 3.4 Ma, Palynomorph Unit 2)

A high but variable in situ palynomorph abundance (between 1 and 295 GPG) and relatively low numbers of Leiospheridia over the mid-Pliocene period (Palynomorph Unit 2, Section 4.4) suggest that this may be the warmest interval recorded in the upper $600 \mathrm{~m}$ of the AND-1B core. The Ross Sea was highly productive and likely ice-free for $\sim 1.2 \mathrm{Ma}$. This interval also exhibits the lowest abundance of terrestrial palynomorphs (Figure 6) suggesting: a) that the terrestrial contribution of the palynomorph record is reworked, and/or b) that there was no significant 
terrestrial biosphere in Antarctica during the warmest period of the Pliocene. Naish et al. (2009a) demonstrate that the thick diatomite unit spanning this interval in the core likely indicates ice-free marine conditions in the Ross embayment.

Sjunneskog et al. (2010) analysed the marine diatoms from a section of the mid-Pliocene interval of the AND-1B core (within Palynomorph Unit 2). Over the $\sim 100 \mathrm{~m}$ interval studied ( 460 - 360 mbsf) Sjunneskog et al. (2010) demonstrate that there is significantly less sea-ice by the very low presence ( $3 \%$ ) of Fragilariopsis curta (that typically accounts for $20-80 \%$ of the modern Antarctic diatom assemblage), and that the environment was warmer and more productive, indicated by the relatively high abundance of sub-Antarctic Zone (SAZ) species. Their results are in agreement with the findings presented here: that the mid-Pliocene was significantly warmer, and more productive than the modern McMurdo environment (Figure $10)$.

Silicoflagellate records in sediments surrounding Antarctica suggest three intervals (4.6-4.8, 4.34.4 and 3.7 Ma) where the temperature of the Southern Ocean was $\sim 5^{\circ} \mathrm{C}$ warmer than modern (Haywood et al., 2009).

Modeling suggests that although a floating ice shelf near the AND-1B site may have appeared at $\sim 4 \mathrm{Ma}$, it did not become a stable feature there or in the Ross embayment until $\sim 3 \mathrm{Ma}$, and open ocean conditions persisted between $\sim 4$ and $3 \mathrm{Ma}$.

Global climate conditions of the early-Pliocene (above) persisted through the mid-Pliocene. Atmospheric $\mathrm{CO}_{2}$ concentrations were 400 ppm (Raymo et al. 1996; Tipple et al. 2010), global temperatures were $\sim 3^{\circ} \mathrm{C}$ higher than modern (Dowsett et al. 1994), and eustatic sea-level was $\sim 25$ meters higher than modern (Miller et al. in press).

Interpretation: All evidence from the ANDRILL MIS project indicates that the mid-Pliocene 
period (4.6-3.4 Ma) is the warmest recorded interval from the core and that the Ross embayment exhibited open marine, ice-free conditions. The WAIS was likely very small or nonexistent during this interval and the EAIS was likely restricted to terrestrial margins. Variability in the Earth's climate on a $\sim 40$ kyr periodicity persisted throughout this interval, but cooling events were not intense enough to cause significant changes in polar ice volume. Global temperatures were $+3^{\circ} \mathrm{C}$ or more compared to modern, and eustatic sea level was likely $+25 \mathrm{~m}$ or higher than modern. The termination of this warm period was not sudden but likely to have been a continual process that progressed into the late-Pliocene.

Late-Pliocene ( 3.4 - 2.6 Ma, Palynomorph Units 3,4 \& 5)

Trends in the palynomorph assemblage observed throughout the late-Pliocene show few major changes, but subtle variations allowed this interval to be divided into 3 separate units: Palynomorph Units 3, $4 \& 5$ (see Section 4.4). Across all three of these units the overall assemblage suggests that conditions were warmer than modern, and oceanic productivity was higher as a result (Figure 10). Variation in the assemblage of palynomorphs across this interval also suggests that there was an ice sheet that periodically approached or even covered the AND1B drill site during the coldest periods, and then retreated or completely collapsed during the warmest (Section 4.4). Palynomorph Unit 3, the oldest unit in this interval exhibits an overall low abundance of palynomorphs ( $\leq 15 \mathrm{GPG}$ ) indicating that conditions were colder than those of the mid-Pliocene, but the assemblage suggests that the paleoenvironmental conditions were warmer than modern conditions. Palynomorph Unit 4 is very similar to Unit 3 but exhibits a slightly lower overall abundance ( $\leq 13 \mathrm{GPG}$ ), and a greater percentage of palynomorphs indicative of a colder, less productive environment. Palynomorph Unit 5 exhibits a relatively high palynomorph abundance ( $\geq 42 \mathrm{GPG}$ ) and is dominated by palynomorphs indicative of 
warmer conditions and a more productive ocean. In a sample within Unit $5(\sim 224 \mathrm{mbsf})$, a spike in Cymatiosphaera, generally considered an indicator of reduced salinity, may be the result of a regional Antarctic melting event, indicating the rapidity of what may be the collapse of the WAIS.

The sedimentology of the AND-1B core over the late-Pliocene period is highly variable (Naish et al., 2009a), consisting of alternating beds of diatomite (warmer, open ocean), and diamictite (colder with ice proximal to/covering drill site) indicating a variable climate.

Naish et al. (2009b) and Haywood et al. (2009) present evidence of a highly variable WAIS during this interval and suggest eustatic sea level changes of up to $\sim 20-30 \mathrm{~m}$. Haywood et al. (2009) also suggest that the EAIS was restricted to the terrestrial margin throughout the Pliocene. Naish et al. (2009b) present evidence from sedimentological studies based at locations around Antarctica which indicate a cooling and ice-sheet expansion from 3.0-2.5 Ma.

Global climate records indicate that the warmest interval of the Pliocene (known as the MidPliocene climatic optimum) occurred between $3.3 \mathrm{Ma}$ when temperatures peaked at $3^{\circ} \mathrm{C}$ higher than modern, to when temperatures began cooling at $~ 3.0 \mathrm{Ma}$ (Raymo, et al., 2006). Raised coastal terraces and sea level reconstructions by Raymo et al. (2006) suggest that there was EAIS melting during the climatic optimum, raising eustatic sea level by 10 to $40 \mathrm{~m}$. Ravelo et al. (2004) show that a major high-latitude climate reorganization/cooling occurred between 3.0 to $2.0 \mathrm{Ma}$ and included surface water stratification of the North Pacific ocean and a reduction in the thermohaline overturning, the biggest global ocean heat conveyor.

Interpretation: From 3.4 to $3.0 \mathrm{Ma}$, Antarctica exhibits signs of a significantly warmer climate despite the presence of a dynamic WAIS. Expansions in WAIS are recorded in sediments around Antarctica and continue to be driven by cycles in the Earth's axial tilt (obliquity) on a $\sim 40 \mathrm{kyr}$ cycle. During the Pliocene climatic optimum the Earth was experiencing warm temperatures 
$\left(+3^{\circ} \mathrm{C}\right)$ and significant eustatic sea level rises (up to $+40 \mathrm{~m}$ ). Some time after $\sim 3.2 \mathrm{Ma}$, global temperatures began to drop culminating in a climate reconfiguration and possible ice expansion at the poles. From $\sim 3.0$ to $2.6 \mathrm{Ma}$, a relatively high abundance of palynomorphs in the AND-1B core and an assemblage that is indicative of a warmer climate demonstrate that the WAIS was still very dynamic in the late-Pliocene when the global climate was cooling. The coldest periods of the late-Pliocene may still have been warmer than modern conditions.

Latest-Pliocene - Pleistocene ( 2.6 Ma and younger, Palynomorph Unit 6)

Palynomorph Unit 6 (Section 4.4) is characterised by an overall very low abundance of palynomorphs ( $\leq 8 \mathrm{GPG}$ ) and an assemblage dominated by reworked palynomorphs; largely marine Eocene palynomorphs. This suggests a change in palynomorph provenance, and glacial reconfiguration. Few samples show evidence of open ocean conditions at the AND-1B drill site, and the palynological interpretation is that the latest-Pliocene and Pleistocene is the coldest interval identified in the upper $600 \mathrm{~m}$ of the AND-1B core. The change to these 'fully polar' conditions is near instantaneous at the resolution adopted in the palynological study (at least 1 sample every 10 meters) and occurs at $\sim 184 \mathrm{mbsf}(\sim 2.6 \mathrm{Ma})$. Within Unit 6 there are two samples ( 110 and $93 \mathrm{mbsf}$ ) that may record WAIS collapses as indicated by a reduction in reworked palynomorphs and concomitant increase of in situ palynomorphs. The sample from 93 mbsf coincides with the super interglacial Marine Isotope Stage 31 (MIS 31) (Naish et al., 2009a), an extended period of global warmth.

Studies of the late-Pliocene diatoms (Sjunneskog \& Winter, unpublished) have been conducted on a much higher resolution over shorter intervals, giving a much more detailed analysis of the late-Pliocene cooling (and also demonstrating that the coarser resolution of the current palynomorph study is sufficient for resolving significant events, adding confidence to the results 
presented in this study). In the Late-Pliocene, at around $210 \mathrm{mbsf}$ (Figure 9), the diatom assemblage changes up-core over a section of $\sim 20 \mathrm{~m}$. The sea-ice indicators (F. curta, $E$. antarctica and $S$. microtrias) have a relatively low but constant presence below $200 \mathrm{mbsf}$, suggesting that conditions were warmer than today throughout this $10 \mathrm{~m}$ interval. At around 200 mbsf, warm water indicators (S. stellaris, F. laqueus, F. bohatyii, T. inura and S. tetraoestrupii) all reduce in overall percentage, while the indicators of colder conditions (A. karstenii and $F$. robusta) increase. The shift to cold climate indicators culminates at $\sim 190 \mathrm{mbsf}$. This agrees with the change seen in the palynomorph assemblage across the Unit 5/6 boundary (Figure 10). Examining the clast provenance of the AND-1B core (Talarico et al., 2010), an up-core increase in TAM-sourced clasts is identifiable at around $\sim 184 \mathrm{mbsf}$ (Figure 8 ). The increase in TAMsourced material may be the result of the expansion of the EAIS, increasing ice volumes of EAIS draining glaciers in the TAM and consequently entraining stratagraphically higher sediments. Or the increase may reflect a change in relative ice contribution from the Mullock or Skeleton glacial systems that have slightly varying bedrocks. This change in clast provenance occurs across the same interval and there is a change in palynomorph assemblage that may be the result of a single cause: as temperatures drop, the ice shelf expands over the AND-1B drill site, removing a habitable environment for marine palynomorphs. The expansion of the west and east Antarctic ice sheets increases glacial erosion and sediment supply to the basin, resulting in subglacial/icesheet deposition of the Eocene dinoflagellate cysts that dominate the latest-Pliocene and Pleistocene. A second major up-core increase in TAM sourced clasts is noted at $\sim 84 \mathrm{mbsf}$ and is interpreted as a further cooling and glacial reconfiguration.

Using sedimentary motifs (Section 2.1) McKay et al. (2009) identify the boundary between 'sub-polar' (Motif 2) and 'polar' (Motif 1) conditions at 82 mbsf (Figure 9), whereas changes in marine palynology suggest that the sub-polar to polar boundary is at $\sim 184 \mathrm{mbsf}$ (Unit 5/6 
boundary). This $100 \mathrm{~m}(1.6 \mathrm{Ma})$ discrepancy may be describes as follows: The change in the marine palynomorph assemblage from an assemblage dominated by in situ palynomorphs to one that is dominated by reworked palynomorphs (Unit $5 / 6$ boundary) records the onset of the major cooling step. As the temperature drops, subtle changes in the ice volume and glacial dynamics make the area at the AND-1B drill site less habitable to palynomorphs and the changing glacial regime begins to erode and deposit Eocene palynomorphs at the drill site. The much younger change in sedimentary motifs (Motif $2 / 1$ boundary) is only reached once fully polar conditions are established. The marine palynomorphs inhabiting the drill site are responding quickly to subtle changes in temperature and ice proximity, whereas sedimentary motifs are responding to major changes in the glacial regime, driven by major temperate changes. Identified changes in sedimentation style from seismic studies and core data around Antarctica suggest a regional cooling and ice sheet expansion from $\sim 3$ to $2.5 \mathrm{Ma}$ (Naish et al., 2009b). Sedimentological evidence from Prydz Bay (Naish et al., 2009b) reveals that there was a Pleistocene shift to colder, dry-based EAIS. Foraminiferal and coccolith records from the Weddell Sea and Prydz Bay give insights into the extent of Antarctic warming during MIS 31 (Naish et al., 2009b), revealing a $4-6^{\circ} \mathrm{C}$ increase in sea surface temperature in these areas. Modeling by Pollard and DeConto (2009) suggests that 'similar to modern'-to-'fully glaciated' ice volumes became more common in Antarctica from $3 \mathrm{Myr}$, a fully glaciated WAIS with grounded ice covering the AND-1B site becoming common from $\sim 1.5 \mathrm{Ma}$. The model also suggests the collapse of the WAIS during MIS 31.

As noted above, there was a high-latitude climate cooling and reorganization identified between 3 and 2.5 Ma in global climate records (Ravelo et al., 2004). The initiation of northern hemisphere glaciation is dated to $2.75 \mathrm{Myr}$ ago (Raymo, 1994; Ravelo et al., 2004) coinciding with major shift in palynology is identified in the AND-1B core. A shift in global climate cycles 
is identified as occurring after MIS 31 , from $\sim 41 \mathrm{kyr}$ glacial/interglacial cycle periods to $\sim 100$ kyr cycle periods.

Interpretation: Global cooling throughout the latest-Pliocene culminated in a high-latitude climate reconfiguration at $\sim 2.6 \mathrm{Ma}$. The initiation of the northern hemisphere glaciation may have led the ice expansion across Antarctica identified in the paleontology and sedimentology. Evidence presented here suggests an abrupt cooling in Antarctica 2.6 Myr ago, followed by further cooling throughout the Pleistocene. MIS 31 punctuates the seemingly persistent 'polar' conditions in Antarctica during the Pleistocene with brief warm conditions. During this extended interglacial the WAIS may have collapsed and surrounding SSTs rose by up to $6^{\circ} \mathrm{C}$. 100 kyr cycles took over from the 40 kyr cycles following MIS 31, and all evidence indicates the coldest conditions in Antarctica persisted throughout the late-Pleistocene. 


\subsection{CONCLUSION}

Throughout the upper $600 \mathrm{~m}$ of the AND-1B core a range of in situ and reworked fossil dinoflagellate cysts, acritarchs, prasinophyte algae and terrestrial palynomorphs were recovered and identified. The assemblage and distribution of these palynomorphs over the PlioPleistocene interval of the core give detailed insights into the local and regional paleoenvironment and glacial dynamics.

A relatively high abundance of in situ marine palynomorphs throughout the early-Pliocene ( $~ 5.0$ - 4.6 Ma, Palynomorph Unit 1) suggests variability in the climate but overall warmer, more productive oceans and no permanent ice cover at the drill site. The palynology of the midPliocene ( 4.6 - 3.4 Ma, Palynomorph Unit 2) continues to suggest variability within the climate but overall warmer, more productive conditions. A peak in palynomorph abundance (235 GPG), dominated by round brown in situ dinoflagellate cysts suggests that this could be the warmest recorded interval and that ice free conditions may have persisted in the Ross embayment for $\sim 1.2 \mathrm{Ma}$. The mid- to late-Pliocene ( 3.4 - 2.6 Ma, Palynomorph Units 3, 4 \& 5) palynomorph assemblage is highly variable but still indicative of warmer than modern conditions. Variability between a palynomorph assemblage dominated by round brown dinoflagellate cysts and microforaminiferal linings (considered to represent a warmer, more productive environment) and an assemblage dominated by Leiospheridia and terrestrial palynomorphs (considered to represent a cooler, less productive environment) indicates constant variability in paleoenvironmental conditions. The variability in palynology within single lithological units demonstrates the sensitive nature of the palynological record to environmental changes. A high-resolution palynological analysis over several lithological units may reveal distinct climate cycles not as easily identified using other proxies (e.g. lithology). A spike in the prasinophyte alga Cymatiosphaera, understood to indicate reduced salinity, may be a 
record of a large meltwater influx into the Ross embayment, due to the collapse of the WAIS. A high-resolution analysis of the abundance of prasinophyte algae within the sediment surrounding the Cymatiosphaera dominated sample may give valuable insight into the pace of a WAIS collapse. A significant shift in the palynomorph assemblage is observed during the latestPliocene ( 2.6 Ma, Palynomorph Unit 5/6 boundary), from an assemblage dominated by in situ marine palynomorphs to an assemblage dominated by reworked marine palynomorphs. This change is interpreted as recording significant cooling and permanent ice cover being established at the drill site. Apart from two samples that contain increased abundances of in situ palynomorphs, the reworked dominated assemblage persists until the core top, suggesting that modern 'polar' conditions may have first been established in the latest-Pliocene $(\sim 2.6 \mathrm{Ma})$. The reworked assemblage largely comprises of Eocene dinoflagellate cysts and acritarchs that are rare prior to this interval. This suggests a change in sediment provenance, likely due to a rearrangement in glacial flow.

Marine palynomorphs from the AND-1B core clearly demonstrate their usefulness in interpreting local and regional paleoenvironmental conditions. Further, higher resolution analysis on the marine palynomorphs throughout the Plio-Pleistocene interval of the AND-1B core would contribute significantly to the understanding of climate cycles exhibited in Antarctica. More detailed inferences could also be made about the rapidity of the WAIS growth and decay and estimates of water depth at the drill site may be made possible through the detailed study of scolecodonts recorded in the core. 


\subsection{REFFERENCES}

Archangelsky, S. (1969). Sobre el paleomicroplancton del Terciario inferior de Rio Turbio, Provincia Santa Cruz. Ameghiniana, 5(10), 406-416.

Artzner, D.G. \& Dörhöfer, G. (1978). Taxonomic note: Lejeunecysta nom. Nov. pro Lejeunia Gerlach 1961 emend. Lentin \& Williams 1976 - dinoflagellate cyst genus. Canadian Journal of Botany, 56, 1381-1382.

Askin, R. A., \& Raine, J. I. (2000). Oligocene and Early Miocene terrestrial palynology of the Cape Roberts Drillhole CRP-2/2A, Victoria Land Basin, Antarctica. Terra Antartica, $7(4), 493-501$.

Barrett, P.J. (1999). Antarctic climate history over the last 100 million years. Geological records of Global and Planetary change. Terra Antartica Rpts., col, 3, 53-72.

Barrett, P.J., Carter, L., Dunbar, G., Giorgetti, G., Harper, M., McKay, R., Niessen, F., et al. (2005). Oceanography and sedimentation beneath the McMurdo Ice Shelf in Windless Bight, Antarctica. Antarctic Data Series.

Barrett, P.J., \& Hambrey, M.J. (1992). Plio-Pleistocene sedimentation in Ferrar Fiord, Antarctica. Sedimentology, 39(1), 109-123.

Barrett, P.J., Sarti, M. M., \& Wise, S. (2000). Studies from the Cape Roberts Project, Ross Sea, Antarctica: Initial report on CRP-3. Terra Antartica, 7(1/2), 1-209.

Barrett, P.J. (1986). Antarctic Cenozoic history from the MSSTS-1 drillhole, McMurdo Sound, Antarctica. NZ DSIR Bulletin, 237, 174.

Barrett, P.J. (1989). Antarctic Cenozoic history from the CIROS-1 drillhole, McMurdo Sound. DSIR Publishing. 
Barrett, P.J., Treves, S. B., Barnes, C. G., Brady, H. T., McCormick, S. A., Nakai, N., Oliver, J., et al. (1976). Initial Report of DVDP 15, western McMurdo Sound, Antarctica.Dry Valley Drilling Project (DVDP), 7, 1-60.

Benedek, P.N., \& Gocht, H. (1981). Thalassiphora pelagica (Dinoflagellata, Tertiär): electronenmikroskopische Untersuchung und Gedanken zur Paläobiologie. Palaeontographica, Abteilung B, 180,313-356.

Bujak, J.P., Downie, C., Eaton, G.L., \& Williams, G.L. (1980). Dinoflagellate cysts and acritarchs from the Eocene of southern England. Special Papers in Palaeontology, (24), 100.

Clark, P. U., \& Huybers, P. (2009). Global change: Interglacial and future sea level.Nature, 462(7275), 856-857.

Cookson, I.C. and Eisenack, A. (1962). Additional microplankton from Australian Cretaceous sediments. Micropaleontology, 8(4), 485-507.

Cookson, I. C., \& Eisenack, A. (1965). Microplankton from the Dartmoor Formation, SW Victoria.P roceedings of the Royal Society of Victoria, 79, 133-137.

Cooper, A., Brancolini, G., Escutia, C., Kristoffersen, Y., Larter, R., Leitchenkov, G., O'Brien, P., \& Jokat, W. (2009). Cenozoic Climate History from Seismic Reflection and Drilling Studies on the Antarctic Continental Margin. In: Florindo, F., \& Siegert, M. (Eds.), Antarctic Climate Evolution. Oxford: Elsevier. 115-234.

Cooper, A. K., \& Davey, F.J. (1985). Episodic rifting of Phanerozoic rocks in the Victoria land Basin, western Ross Sea, Antarctica.Science, 229(4718), 1085.

Cooper, A. K., Davey, F.J., \& Behrendt, J. C. (1987). Seismic stratigraphy and structure of the Victoria Land basin, western Ross Sea, Antarctica. The Antarctic continental margin: geology and geophysics of the western Ross Sea, 5, 27-76. 
Davey, R.J. (1969). Non-calcareous microplankton from the Cenomanian of England, northern France and North America, part I. British Museum (Natural History) Geology, Bulletin, 17, 103-180.

Davey, R.J., \& Williams, G. L. (1966). The genera Hystrichosphaera and Achomosphaera. Bull. Br. Mus. Nat. Hist. GeolSupp, 3, 2-8.

Davey, R.J., \& Williams, G.l. (1966). V. The genus Hystrichosphaeridium and its allies. In: Davey, R.J., Downie, C., Sajeant, W.A.S. \& Williams, G.L., Appendix to “Studies on Mesozoic and Cainozoic dinoflagellate cysts; British Museum (Natural History) Geology, Bulletin, Supplement 3, 55-106.

DeConto, R. M., \& Pollard, D. (2003). Rapid Cenozoic glaciation of Antarctica induced by declining atmospheric $\mathrm{CO}_{2}$. Nature, 421(6920), 245-249.

Deflandre, G. (1937). Microfossiles des silex crétacés. II. Flagellés incertae sedis. Hystrichosphaeridées. Sarcodines. Organismes divers. Ann. Paléont, 26, 51-103.

Deflandre, G. (1954). Systématique des Hystrichosphaeridés: sur l'acception du genre Cymatiosphaera O. Wetzel. Compte Rendu sommaire des Séances de la Société géologique de France, 12, 257-258.

Dotzler, N., Taylor, T.N., \& Krings, M. (2007). A prasinophycean alga of the genus Cymatiosphaera in the Early Devonian Rhynie chert. Review of Palaeobotany and Palynology, 147(1-4), 106-111.

Dowsett, H., Thompson, R., Barron, J., Cronin, T., Fleming, F., Ishman, S., Poore, R., et al. (1994). Joint investigations of the Middle Pliocene climate I: PRISM paleoenvironmental reconstructions. Global and Planetary Change, 9(3-4), 169-195. 
Ehrenberg, C.G. (1838). Über das Massenverhältniss der jetzt lebenden Kiesel-Infusorien und über ein neues Infusorien-Conglomerat als Polierschiefer von Jastraba in Ungarn. Königlich Akademie der Wissenschaften zu Berlin, Abhandlungen, 1836, 1, 109-135.

Eisenack, A. (1938). Die Phosphoritknollen der Bernsteinformation als Überlieferer tertiären Planktons. Schriften der Physikalisch-Ökonomischen Gesellschaft zu Königsberg, 70(2), 181-188.

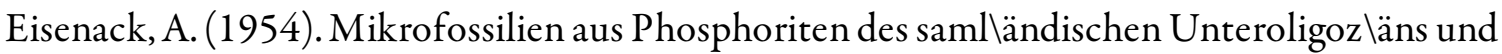
lüber die Einheitlichkeit der Hystrichosphaerideen. Palaeontographica, Abteilung A, $105,49-95$.

Eisenack, A. (1958). Tasmanites Newton 1875 und Leiosphaeridia ng als Gattungen der Hystrichosphaeridea. Palaeontographica Abteilung A, 110(1-3), 1-19.

Eisenack, A., \& Gocht, H. (1960). Neue Namen für einige Hystrichosphären der Bernsteinformation Ostpreussens. Neues Jahrbuch für Geologie und Paläontologie, Monatshefte, 11,511-518.

Falconer, T., Pyne, A., Levy, R., Olney, M., \& Curren, M. (2007). Operations Overview for the ANDRILL McMurdo Ice Shelf Project, Antarctica. Terra Antarctica, 14(3), 131-140.

Fielding, C. R., Henrys, S. A., \& Wilson, T.J. (2006). Rift history of the western Victoria Land Basin; a new perspective based on integration of cores with seismic reflection data. Antarctica: Contributions to global earth sciences, 309-318.

Fielding, C. R., Whittaker, J., Henrys, S. A., Wilson, T.J., \& Naish, T. R. (2008). Seismic facies and stratigraphy of the Cenozoic succession in McMurdo Sound, Antarctica: Implications for tectonic, climatic and glacial history. Palaeogeography, Palaeoclimatology, Palaeoecology, 260(1-2), 8-29. 
Fielding, C., \& Thomson, M. (1999). Studies from the Cape Roberts Project, Ross Sea, Antarctica: Initial report on CRP-2/2A. Terra Antartica, 6(1/2), 1-173.

Gambi, M.C., Castelli, A., \& Guizzardi, M. (1997). Polychaete populations of the shallow soft bottoms off Terra Nova Bay (Ross Sea, Antarctica): distribution, diversity and biomass. Polar Biology, 17(3), 199-210.

Gerlach, E. (1961). Mikrofossilien aus dem Oligozän und Miozän Nordwestdeutschlands, unter besonderer Berücksichtigung der Hystrichosphären und Dinoflagellaten. Neues Jahrbuch für Geologie und Paläontologie, Abhandlungen, 112(2), 143-228.

Gocht, H. (1968).Zur Morphologie und Ontogenie von Thalassiphora (Dinoflagellata). Palaeontographica, Abteilung A, 129, 149-156.

Hambrey, M.J., Wise, S. W., Barrett, P., Davey, F., Ehrmann, W., Smellie, J., Villa, G., et al. (1998). Scientific Report of CRP-1. Terra Antartica, 5, 713.

Hannah, M.J., Wilson, G.J., \& Wrenn, J.H. (2000). Oligocene and Miocene Marine Palynomorphs from CRP-2/2A, Victoria Land Basin, Antarctica. Terra Antartica, $7(4 / 5), 503-511$.

Hannah, M.J., Wrenn,J.H., \& Wilson, G.J.(1998). Early Miocene and Quaternary marine palynomorphs from Cape Roberts project CRP-1, McMurdo Sound, Antarctica. Terra Antartica, 5(3), 527-538.

Harland, R., FitzPatrick, M., \& Pudsey, C.J. (1999). Latest Quaternary dinoflagellate cyst climatostratigraphy for three cores from the Falkland Trough, Scotia and Weddell seas, Southern Ocean. Review of Palaeobotany and Palynology, 107(3-4), 265-281. 
Harland, R., Pudsey, C.J., Howe, J. A., \& Fitzpatrick, M.E. (1998). Recent dinoflagellate cysts in a transect from the Falkland Trough to the Weddell Sea, Antarctica. Palaeontology, 41(6), 1093-1132.

Harland, R. (1989). A dinoflagellate cyst record for the last 0.7 Ma from the Rockall Plateau, northeast Atlantic Ocean.Journal of Geological Society, 146(6), 945.

Hayes, D. E., \& Frakes, L. A. (1975). General synthesis, deep sea drilling project Leg 28. Initial Reports of the Deep Sea Drilling Project, 28,919-942.

Haywood, A., Smellie, J., Ashworth,A., Cantrill,D., Florindo, F., Hambrey, M., Hill, D., Hillenbrand, C., Hunter, S., Larter, R., Lear, A., Passchier, S., \& van de Wal, R. (2009). Middle Miocene to Pliocene History of Antarctic and Southern Ocean. In: Florindo, F., \& Siegert, M.(Eds.), Antarctic Climate Evolution. Oxford: Elsevier. 401-463.

Helenes, J. (1984). Morphological analysis of Mesozoic-Cenozoic Cribroperidinium (Dinophyceae), and taxonomic implications. Palynology, 8, 107-137.

Horgan, H., Naish, T., Bannister, S., Balfour, N., \& Wilson, G. (2005). Seismic stratigraphy of the Plio-Pleistocene Ross Island flexural moat-fill: A prognosis for ANDRILL program drilling beneath McMurdo-Ross Ice Shelf. Global and planetary change, 45(1-3), 8397.

IPCC. (2007). Climate Change 2007. The Physical Science Basis: Contribution of Working Group I to the Fourth Assessment Report of the Intergovernmental Panel on Climate Change.

Khowaja-Ateequzzaman, Garg, R., \& Jain, K.P. (1991) Some observations on dinoflagellate cyst genus Alterbidinium Lentin and Williams 1985. The Palaeobotanist, 39(1), 37-45. 
Kjellström, G. (1972). Archaeopyle formation in the genus Lejeunia Gerlach, 1961 emend. Geologiska Föreningens i Stockholm Förhandlingar, 94, 467-469.

Krissek, L., Browne, G., Carter, L., Cowan, E., Dunbar, G., McKay, R., Naish, T., et al. (2007). Sedimentology and Stratigraphy of the AND-1B Core, ANDRILL McMurdo Ice Shelf Project, Antarctica. Terra Antarctica, 14(3), 185-222.

Lentin,J.K., \& Williams, G.L.(1976). A monograph of fossil peridinioid dinoflagellate cysts. Bedford Institute of Oceanography, Report Series, no.BI-R-75-16, 237.

Levy, R. H., \& Harwood, D. M. (2000). Tertiary marine palynomorphs from the McMurdo Sound erratics, Antarctica. Paleobiology and Paleoenvironments of Eocene Rocks, McMurdo Sound, East Antarctica. Antarct. Res. Ser, 76, 183-242.

Mantell, G.A.(1850). A Pictorial Atlas of Fossil Remains Consisting of Coloured Illustrations Selected from Parkinson's “Organic Remains of a Former World”, and Artis’s “Antediluvian Phytology”. xii+207; Henry G. Bohn, London, U.K.

Mantell, G.A. (1854). The Medals of Creation; or, First Lessions in Geology and the Study of Organic Remains; Second Edition. 930. (in two volumes); Henry G. Bohn, London, U.K. Matsuoka, K., McMinn, A., \& Wrenn, J.H. (1997). Restudy of the holotype of Operculodinium centrocarpum (Deflandre \& Cookson) Wall (Dinophyceae) from the Miocene of Australia, and the taxonomy of related species. Palynology, 21, 19-33.

McKay, R., Browne, G., Carter, L., Cowan, E., Dunbar, G., Krissek, L., Naish, T., et al. (2009). The stratigraphic signature of the late Cenozoic Antarctic Ice Sheets in the Ross Embayment. Geological Society of America Bulletin, 121(11-12), 1537. 
McKay, R. M., Barrett, P.J., Harper, M. A., \& Hannah, M.J. (2008). Atmospheric transport and concentration of diatoms in surficial and glacial sediments of the Allan Hills, Transantarctic Mountains. Palaeogeography, Palaeoclimatology, Palaeoecology, 260(12), $168-183$.

McLean, D.M.(1976).Eocladopyxispeniculatum Morgenroth, 1966, Early Tertiary ancestor of the modern dinoflagellate Pyrodinium bahamense Plate, 1906. Micropaleontology, 22, $347-351$

Miller, K. G., Browning, J. V., Kulpecz, A., Kominz, M., Naish, T. R., Rosenthal, Y., Peltier, R., Sosdian, S., Wright, J.D. (2010). The high tide of the warm Pliocene: Implications of 20 m peak eustatic sea-levels for Antarctic deglaciation. Manuscript submitted for publication.

Morgenroth, P.(1966). Mikrofossilien und Konkretionen des Nordwesteuropäischen Untereozäns. Palaeontographica Abt, 119, 1-53.

Mudie, P.J. (1992). Circum-Arctic Quaternary and Neogene marine palynofloras: paleoecology and statistical analysis. Neogene and Quaternary Dinoflagellate Cysts and Acritarchs. American Association of Stratigraphic Palynologists Foundation, College Station, TX, $347-390$.

Naish, T., Carter, L., Wolff, E., Pollard, D., \& Powell, R.. (2009b). Late Pleiocene-Pleistocene Antarctic Climate Variability at Orbital and Suborbital Scale: Ice Sheet, Ocean and Atmospheric Interactions. In: Florindo, F., \& Siegert, M. (Eds.), Antarctic Climate Evolution. Oxford: Elsevier. 465-529. 
Naish, T. R., Powell, R., Barrett, P., Horgan, H., Dunbar, G., Wilson, G., Levy, R., et al. (2005). ANDRILL McMurdo Ice Shelf Project, Scientific Prospectus. ANDRILL Contribution 4.

Naish, T., Powell, R., Levy, R., Wilson, G., Scherer, R., Talarico, F., Krissek, L., et al. (2009a). Obliquity-paced Pliocene West Antarctic ice sheet oscillations. Nature, 458(7236), $322-328$.

Neale,J.W. and Sarjeant, W.A.S. (1962). Microplankton from the Speeton Clay of Yorkshire. Geological Magazine, 99, 439-458.

Pollard, D., \& DeConto, R. M. (2009). Modelling West Antarctic ice sheet growth and collapse through the past five million years. Nature, 458(7236), 329-332.

Prebble, J. G., Hannah, M.J., \& Barrett, P.J. (2006). Changing Oligocene climate recorded by palynomorphs from two glacio-eustatic sedimentary cycles, Cape Roberts Project, Victoria Land Basin, Antarctica. Palaeogeography, Palaeoclimatology, Palaeoecology, $231(1-2), 58-70$.

Ravelo, A. C., Andreasen, D. H., Lyle, M., Lyle, A. O., \& Wara, M. W. (2004). Regional climate shifts caused by gradual global cooling in the Pliocene epoch. Nature, 429(6989), 263267.

Raymo, M.E.(1994). The initiation of Northern Hemisphere glaciation. Annual Review of Earth and Planetary Sciences, 22(1),353-383.

Raymo, M.E., Grant, B., Horowitz, M., \& Rau, G.H.(1996). Mid-Pliocene warmth: stronger greenhouse and stronger conveyor. Marine Micropaleontology, 27(1-4),313-326.

Raymo, M.E., Lisiecki,L.E., \& Nisancioglu, K.H.(2006). Plio-Pleistocene Ice Volume, Antarctic Climate, and the Global $\delta^{18} \mathrm{O}$ Record. Science, 313(5786), 492. 
Sarjeant, W.A.S. (1982). The dinoflagellate cysts of the Gonyaulacysta group: a morphological and taxonomic restudy. American Association of Stratigraphic Palynologists, Contributions Series, (9), 1-81.

Sarjeant, W.A.S. (1984). Re-study of some dinoflagellate cysts from the Oligocene and Miocene of Germany. Journal of Micropalaeontology, 3(2), 73-94.

Sarjeant, W.A.S. (1970). The genus Spiniferites Mantell, 1850 (Dynophyceae. Grana, 10,74-78.

Scherer, R., Hannah, M., Maffioli, P., Persico, D., Sjunneskog, C., Strong, P., Taviani, M., et al. (2007). Palaeontologic Characterisation and Analysis of the AND-1B Core, ANDRILL McMurdo Ice Shelf Project, Antarctica. Terra Antarctica, 14(3), 223-254.

Sicinski, J., \& Janowska, E. (1993). Polychaetes of the shallow sublittoral of Admiralty Bay, King George Island, South Shetland Islands. Antarctic Science, 5(02), 161-167.

Sjunneskog, C., \& Winter, D. (2010). A diatom record of a stepwise late Pliocene cooling from the Ross Sea continental shelf, AND-1B, Antarctica. Unpublished manuscript.

Sjunneskog, C., Winter, D., Harwood, D., \& Scherer, R. (2010).

A diatom-based assessment of Pliocene Antarctic sea ice. Unpublished manuscript.

Stover, L.E. and Evitt, W.R. (1978). Analyses of pre-Pleistocene organic-walled dinoflagellates. Stanford University Publications, Geological Sciences, 15, 300.

Stover, L.E., \& Williams, G. L. (1995). A revision of the Paleogene dinoflagellate genera Areosphaeridium Eaton 1971 and Eatonicysta Stover and Evitt 1978. Micropaleontology, 41(2), 97-141.

Talarico, F. M., McKay, R. M., Powell, R. D.,Sandroni, S., \& Naish, T. (2010). Late Cenozoic oscillations of Antarctic ice sheets revealed by provenance of basement clasts and grain detrital modes in ANDRILL core AND-1B. Global and Planetary Change. 
Tappan, H. (1980). The Paleobiology of Plant Protists. USA: W.H. Freeman.

Tipple, B. J., Meyers, S. R., \& Pagani, M. (2010). Carbon isotope ratio of Cenozoic CO2: A comparative evaluation of available geochemical proxies. Paleoceanography, 25(3).

Truswell, E. M. (1986). Palynology. Antarctic Cenozoic History, MSSTS-1 Drill hole, DSIR Bulletin, 237, 131-134.

Wall, D. (1967). Fossil microplankton in deep-sea cores from the Caribbean Sea. Palaeontology, 10(1), 95-123.

Webb, P. N., Harwood, D. M., McKelvey, B. C., Mercer, J. H., \& Stott, L. D. (1984). Cenozoic marine sedimentation and ice-volume variation on the East Antarctic craton. Geology, $12(5), 287$.

Williams, G.L., \& Downie, C. (1966). Further dinoflagellate cysts from the London Clay. In: Davey, R.J., Downie, C., Sarjeant, W.A.S \& Williams, G.L.Studies on Mesozoic and Cainozoic dinoflagellate cysts; British Museum (Natural History) Geology, Bulletin, Supplement 3,215-236.

Williams, G. L., Lentin, J.K., \& Fensome, R. A. (1998). The Lentin and Williams Index of Fossil Dinoflagellates 1998 Edition. American Association of Stratigraphic Palynologists Foundation, 34 .

Wilson, G., Levy, R., Browne, G., Cody, R., Dunbar, N., Florindo, F., Henrys, S., et al. (2007). Preliminary Integrated Chronostratigraphy of the AND-1B Core, ANDRILL McMurdo Ice Shelf Project, Antarctica. Terra Antarctica, 14(3), 297-316.

Wilson, G.J.(1989). Marine palynology. Antarctic Cenozoic history from the CIROS-1 drillhole, McMurdo Sound, 129-133. 
Wilson, G.J., \& Clowes, C. D. (1980). A concise catalogue of organic-walled fossil dinoflagellate genera. Department of Scientific and Industrial Research.

Wilson, G. (1967). Some new species of lower Tertiary dinoflagellates from McMurdo Sound, Antarctica. New Zealand journal of botany, 5(1), 57-83.

Wrenn, J.H., \& Beckman, S. W. (1982). Maceral, Total Organic Carbon, and Palynological Analyses of Ross Ice Shelf Project Site J9 Cores. Science, 216(4542), 187 - 189.

Wrenn,J.H., \& Hart, G. F. (1988). Paleogene dinoflagellate cyst biostratigraphy of Seymour Island, Antarctica. Geology and Paleontology of Seymour Island, Antarctic Peninsula, Memoir of the Geological. Society of America., 169, 321-447. 


\section{APPENDIX A TAXONOMIC CHECKLIST \& NOTES}

\section{DINOFLAGELLATA:}

Genus: Alterbidinium Lentin \& Williams, 1985; emend. Khowaja-Ateequzzaman \&Jani, 1991.

Alterbidinium sp.

Plate 1 Image 1

In: Levy \& Harwood (2000)

Age: Unknown

Genus: Cribroperidinium Neale \& Sarjeant, 1962; emend. Davey, 1969; emend. Sarjeant, 1982; emend. Helenes 1984.

Cribroperidinium sp.

Plate 1 Image 2

In: Levy \& Harwood (2000)

Age: Unknown

Genus: Deflandrea Eisenack, 1938; emend. Williams \& Downie, 1966; emend. Lentin \& Williams, 1976.

Deflandrea antarctica Wilson, 1967

Plate 1 Image 3

In: Levy \& Harwood (2000)

Age: ?Eocene

Genus: Enneadocysta Stover \& Williams, 1995.

Enneadocysta partridgei Stover \& Williams, 1995

Plate 1 Image 4

In: Levy \& Harwood (2000)

Age: Bartonian-Rupelian 
Genus: Eocladopyxis Morgenroth, 1966; emend. Stover \& Evitt, 1978.

Eocladopyxis peniculata Morgenroth, 1966; emend. McLean, 1976.

Plate 1 Image 5

In: Levy \& Harwood (2000)

Age: Early Eocene

Genus: Eatonicysta sp. Stover \& Evitt, 1978; emend. Stover and Williams, 1995.

Plate 1 Image 6

In: Wilson \& Clowes (1980)

Age: Unknown

Remarks: Eatonicysta is characterized by its long processes and near complete ectophragm but its identification here is treated with caution because it appears to occur ' in situ' well outside of its published - Eocene - stratigraphic range (Davey \& Williams, 1966). Although there is a significant component of reworked Eocene dinoflagellate cysts in this core, Eatonicysta(?) has been considered in situ here because of the excellent preservation of its delicate ectophragm in three samples: L23201, L23206 and L23212 with 110, 8 and 4 specimens respectively. It also has a much fresher appearance than the other Eocene dinoflagellate cysts. The specimens identified in this study can confidently be called in situ in which case they may not be confidently identified as Eatonicysta.

Ecology: Because this specimen can be confidently identified as in situ its occurrence may indicate productive waters but because of its noted difficulty in identification more precise ecological constrains cannot be determined.

Hystrichosphaeridium Deflandre, 1937; emend. Davey \& Williams, 1966. Hystrichosphaeridium sp.

Plate 1 Image 7

In: Levy \& Harwood (2000)

Age: Unknown 
Genus: Impagidinium Stover \& Evitt, 1978.

Impagidinium victorianum (Cookson \& Eisenack, 1965) Stover \& Evitt, 1978.

Plate 1 Image 8

In: Levy \& Harwood (2000)

Age: Late Eocene

Genus: Lejeunecysta Artzner \& Dörhöfer, 1978; emend. Kjellström, 1972; emend. Lentin \& Williams, 1976; emend. Bujak in Bujak et al., 1980

Lejeunecysta hyalina (Gerlach, 1961); emend. Kjellström, 1972; emend. Sarjeant, 1984. Plate 2 Image 1

In: Levy \& Harwood (2000)

Age: Late Oligocene

Genus: Operculodinum Wall, 1967; emend. Matsuoka et al., 1997 Operculodinum bergmanii (Archangelsky, 1969) Stover \& Evitt 1978

Plate 2 Image 2

In: Levy \& Harwood (2000).

Age: Eocene

Genus: Spinidinium Cookson \& Eisenack, 1962; emend. Lentin \& Williams, 1976.

Spinidinium macmurdoense (Wilson, 1967) Lentin \& Williams, 1976.

Plate 2 Image 4

In: Levy \& Harwood, 2000

Age: Early Tertiary

Spinidinium sp.

Plate 2 Image 3

In: Levy \& Harwood, 2000

Age: Unknown 
In: Levy \& Harwood (2000)

Age: Late Cretaceous

\author{
Round brown \\ Plate 2 Image 6
}

In: Harland et al., 1998. Harland, FitzPatrick, \& Pudsey, 1999.

Remarks: Round Brown is most likely a protoperidinioid dinoflagellate with a simple, often spherical, brown to grey cyst (Harland, FitzPatrick, \& Pudsey, 1999; Harland et al., 1998). There are several different species with the same morphological traits, which makes it difficult to distinguish between them, especially if the individual specimens are orientated unfavorably or folded/crushed in any way.

Ecology: Despite their simple morphology most Protoperidinium species are heterotrophic and so are most likely to flourish in waters of high or increased productivity. But because the Round Brown count may include several different species they become limited in their use for age determination and more specific ecological interpretation.

Genus: Thalassiphora Eisenack \& Gocht, 1960; emend. Gocht, 1968; emend. Benedek \& Gocht 1981.

Thalassiphora pelagica (Eisenack, 1954) Eisenack \& Gocht, 1960; emend. Benedek \& Gocht 1981.

Plate 2 Image 7

In: Levy \& Harwood (2000)

Age: Late Eocene to Early Oligocene

Genus: Turbiosphaera Archangelsky, 1969

Turbiosphaera filosa (Wilson, 1967) Archangelsky, 1969

Plate 2 Image 8

In: Levy \& Harwood (2000)

Age: Paleocene - Oligocene 
Genus: Vozzhennikovia Lentin \& Williams, 1976.

Vozzhennikovia apertura (Wilson, 1967) Lentin \& Williams, 1976.

Plate 3 Image 1

In: Levy \& Harwood (2000)

Age: Paleocene - Oligocene

\section{PRASINOPHYCEAE:}

\section{Cymatiosphaera Deflandre, 1954}

Plate 3 Image 2

In: Mudie (1992). Prebble et al. (2006)

Age: Stratigraphic range: Pre-Cambrian - Recent

Ecology: Recent studies have shown that Cymatiosphaera has a preference for waters with reduced salinity such as river outlets, meltwater areas etc. (Mudie, 1992; Prebble et al., 2006). Pulses of Cymatiosphaera are likely to reflect meltwater events in the area where as a constant deposition of them across multiple samples is likely to represent a constant, nearby, freshwater supply.

\section{ACRITARCHA:}

\section{Micrhystridium Deflandre 1937}

Plate 3 Image 3

In: Levy \& Harwood (2000)

Age: Pre-Cambrian - Recent 


\section{Leiospheridia Eisenack, 1958}

Plate 3 Image 4

In: Hannah et al. (2000)

Age: Pre-Cambrian - Recent

Remarks: A featureless subspherical to spherical palynomorph with no apparent ornamentation, tabulation, cingulum or sulcus.

Ecology: Leiospheridia has been shown to be indicative of "stratified glaciofluvial and seasonal meltwater environments" (Mudie, 1992, p. 376). They are noted as living near ice shelf edges. Seasonal ice at the site of their deposition is likely to be represented in the fossil record as their constant presence across samples. Their absence can indicate one of two scenarios: A) the site of deposition has permanent ice cover, or B) the site of their deposition is distal from any ice shelf and is devoid of ice year round.

\section{OTHER PALYNOMORPHS:}

The other palynomorph remains identified in this study are microforaminiferal linings (Plate 3, Image 5), Scolecodonts (Plate 3, Image 6), terrestrial palynomorphs (Plate 3, Images $7 \& 8$ ), zooplankton (Plate 4, Image 1), eggs or egg-casings (Plate 4, Image 2), and unidentified organic sacks (Plate 4, Image 3) 

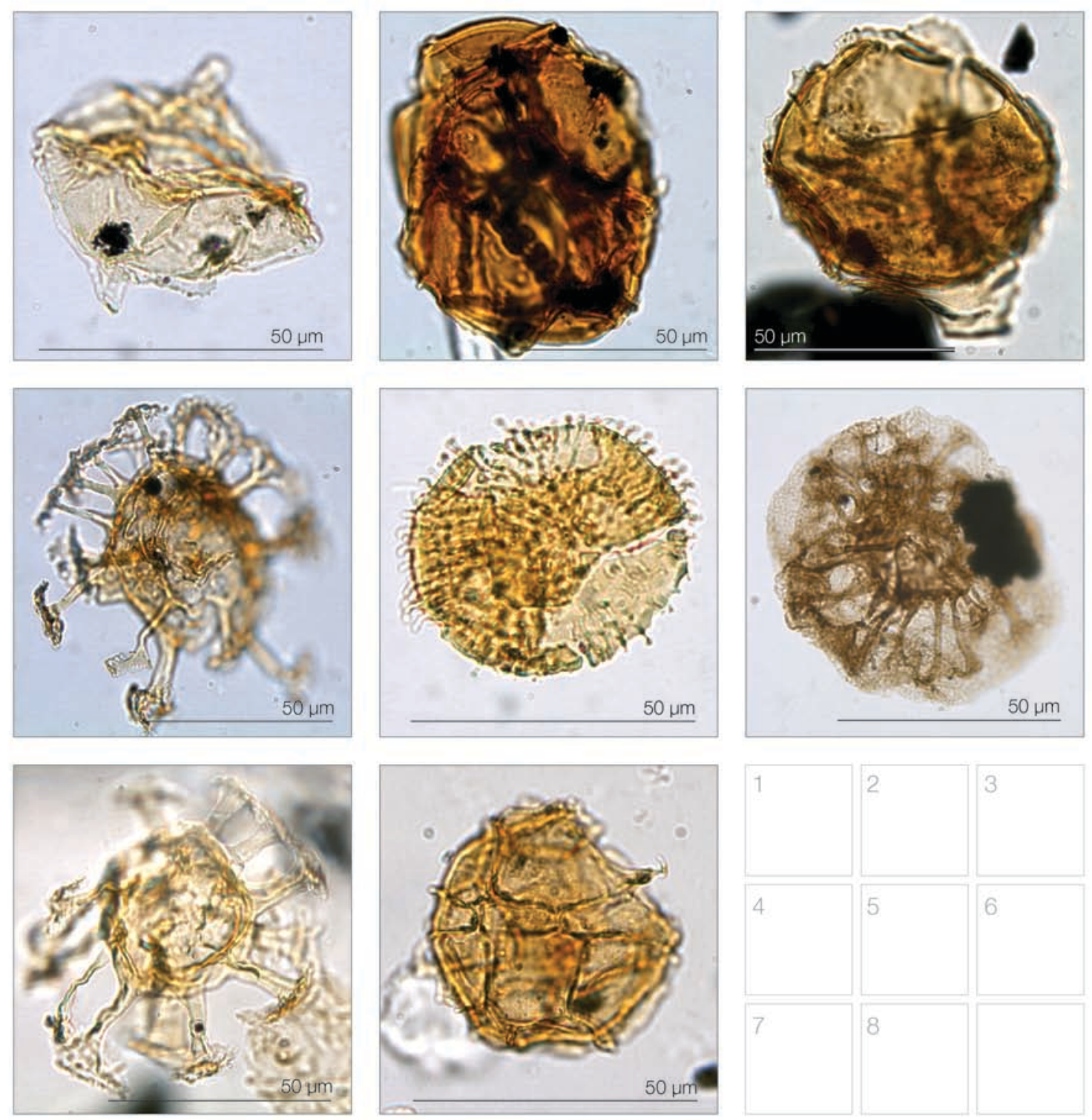

Plate 1 Dinoflagellata

1 Alterbidinium sp. 50 um, (99.97 mbsf, Slide L23208/2, EF: Y34)

2 Cribroperidinium sp(?). 70 m, (60.42 mbsf, Slide L23196/2, EF: O37/3)

3 Deflandrea antarctica. 60 m, (60.42 mbsf, Slide L23196/1, EF: P40)

4 Enneadocysta partridgei. 75 m, (169.60 mbsf, Slide L23198/1, EF: S47/2)

5 Eocladopyxis peniculata(?). 45 m, (80.00 mbsf, Slide L23207/2, EF: W45/2)

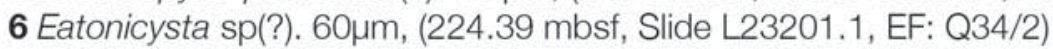

7 Hystrichosphaeridium sp. 65 m, (60.42 mbsf, Slide L23196/2, EF: Z48/1)

8 Impagidinium victorianum. 45 mm, (80.00 mbsf, Slide L23207/2, EF: G46/3) 

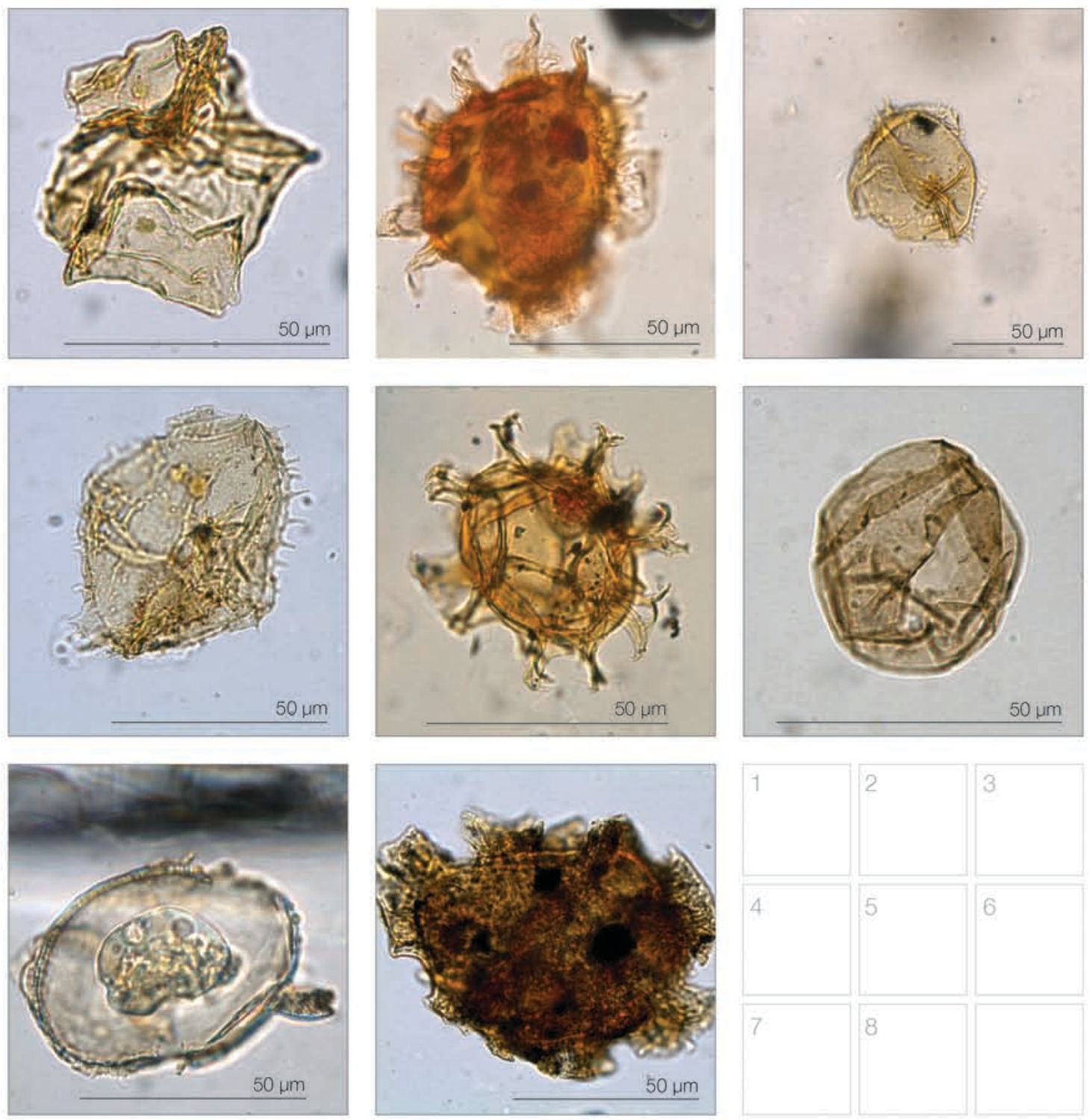

Plate 2 Dinoflagellata

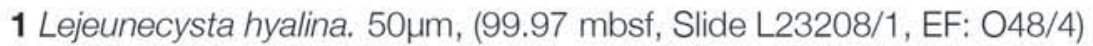

2 Operculodinum bergmanii. 60 m, (130.01 mbsf, Slide L23558/1, EF: D39/1)

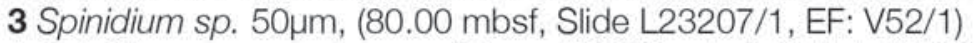

4 Spinidium macmurdoense. 50um, (169.60 mbsf, Slide L23198/2, EF: R41/3)

5 Spiniferites ramosus. 60 m, (170.38 mbsf, Slide L23567.2,EF: P30/3)

6 Round brown. 50 4m, (360.23 mbsf, Slide L23211/1, X46.6:Y98.8)

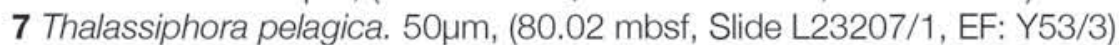

8 Turbiosphaera filosa. $75 \mu \mathrm{m}$, (119.97 mbsf, Slide L23209/1, EF: W47/3) 

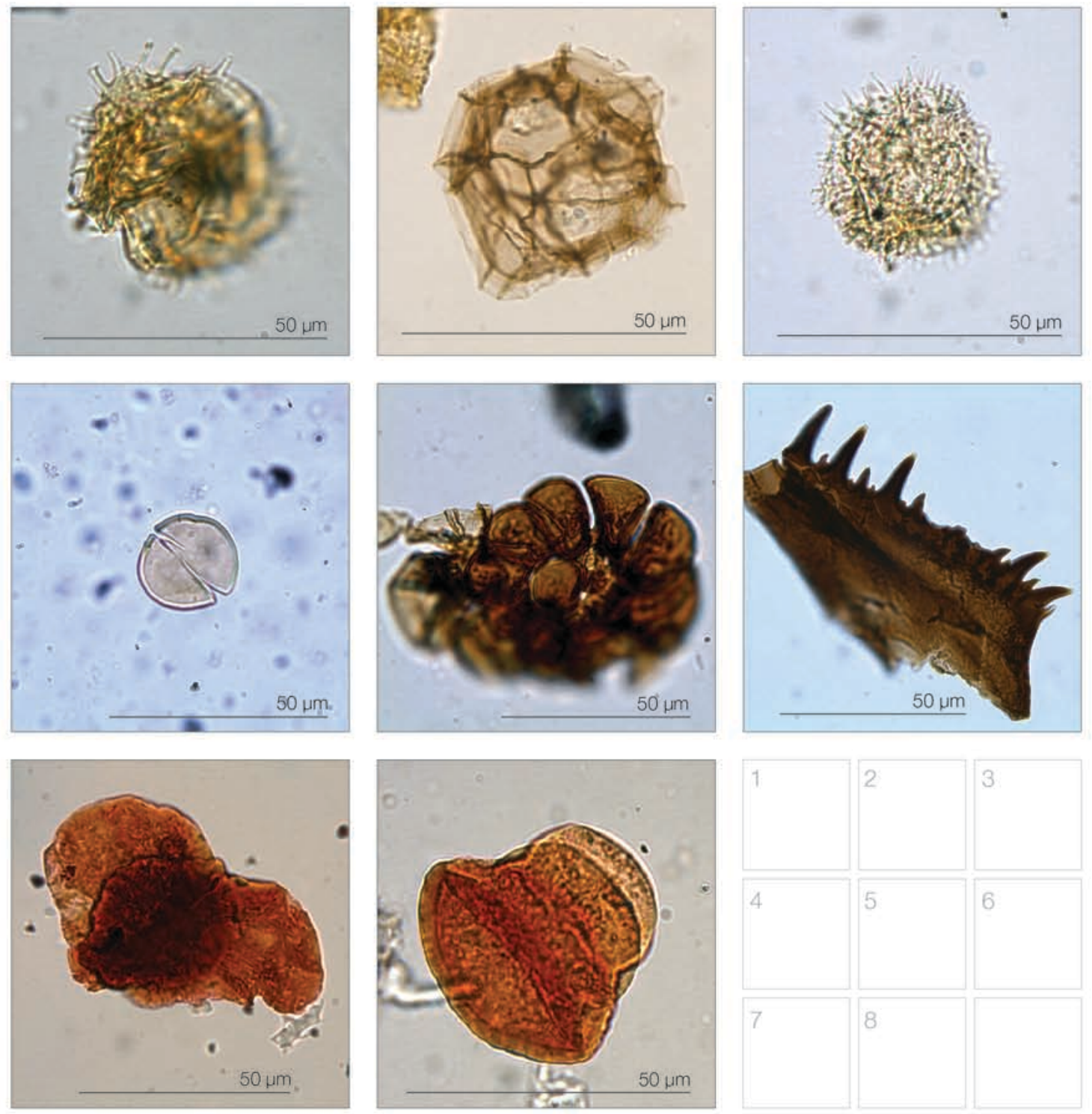

Plate 3 Dinoflagellata, Prasinophyceae, Acritarch, Microforaminifera, Scolecodonts and Terrestrial

1 Vozzhennikovia apertura. 40 m, (60.44 mbsf, Slide L23196/1, EF: Y34)

2 Cymatiosphaera. $45 \mu \mathrm{m},(224.39 \mathrm{mbsf}$, Slide L23201/1, EF: C38/3)

3 Michrystridium. 35 m, (40.73 mbsf, Slide L23195/2, EF: D48/3)

4 Leiosphaeridia. 25 m, (24.33 mbsf, Slide L23194/1, EF: E58/2)

5 Microforaminiferal lining. 65 um, (169.60 mbsf, Slide L23198/1, EF: Y31/4)

6 Scolecodont. 70 um, (184.71 mbsf, Slide L23199/1, EF: Q37)

7 Terrestrial palynomorph. $70 \mu \mathrm{m},(70.63 \mathrm{mbsf}$, Slide L23547/1, EF: U42/3)

8 Terrestrial palynomorph. 45 mm, (30.19 mbsf, Slide L23533/1, EF: U60/2) 

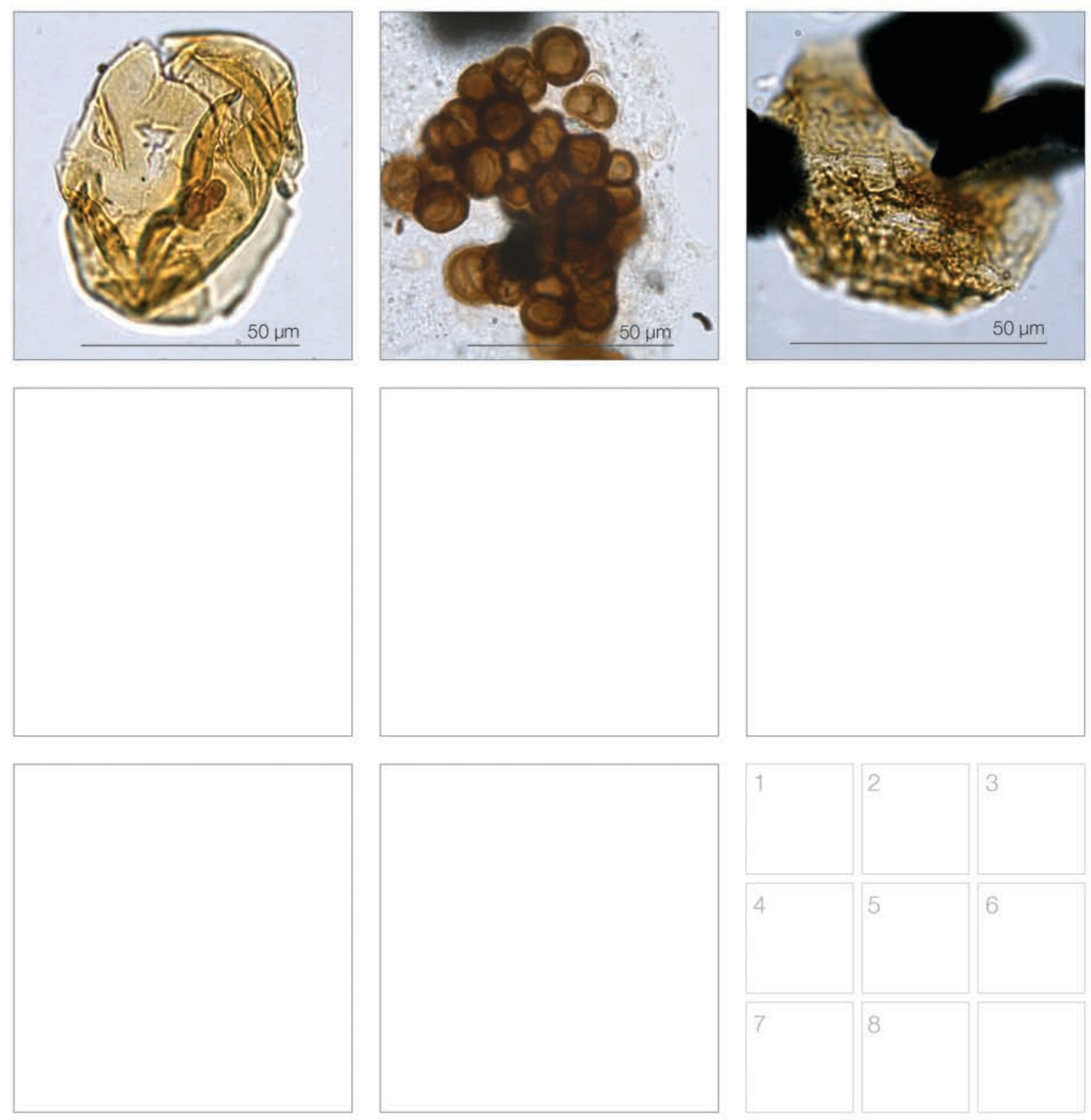

Plate 4 Other Palynomorphs

1 Zooplankton. 50 m, (99.99 mbsf, Slide L23208/1, EF: Y42/3)

2 Eggs. 10 m, (300.40 mbsf, Slide L23205/2, EF: J39/3)

3 Unidentified organic sack. 55 m, (169.61 mbsf, Slide L23198/2, EF: Y50/4) 


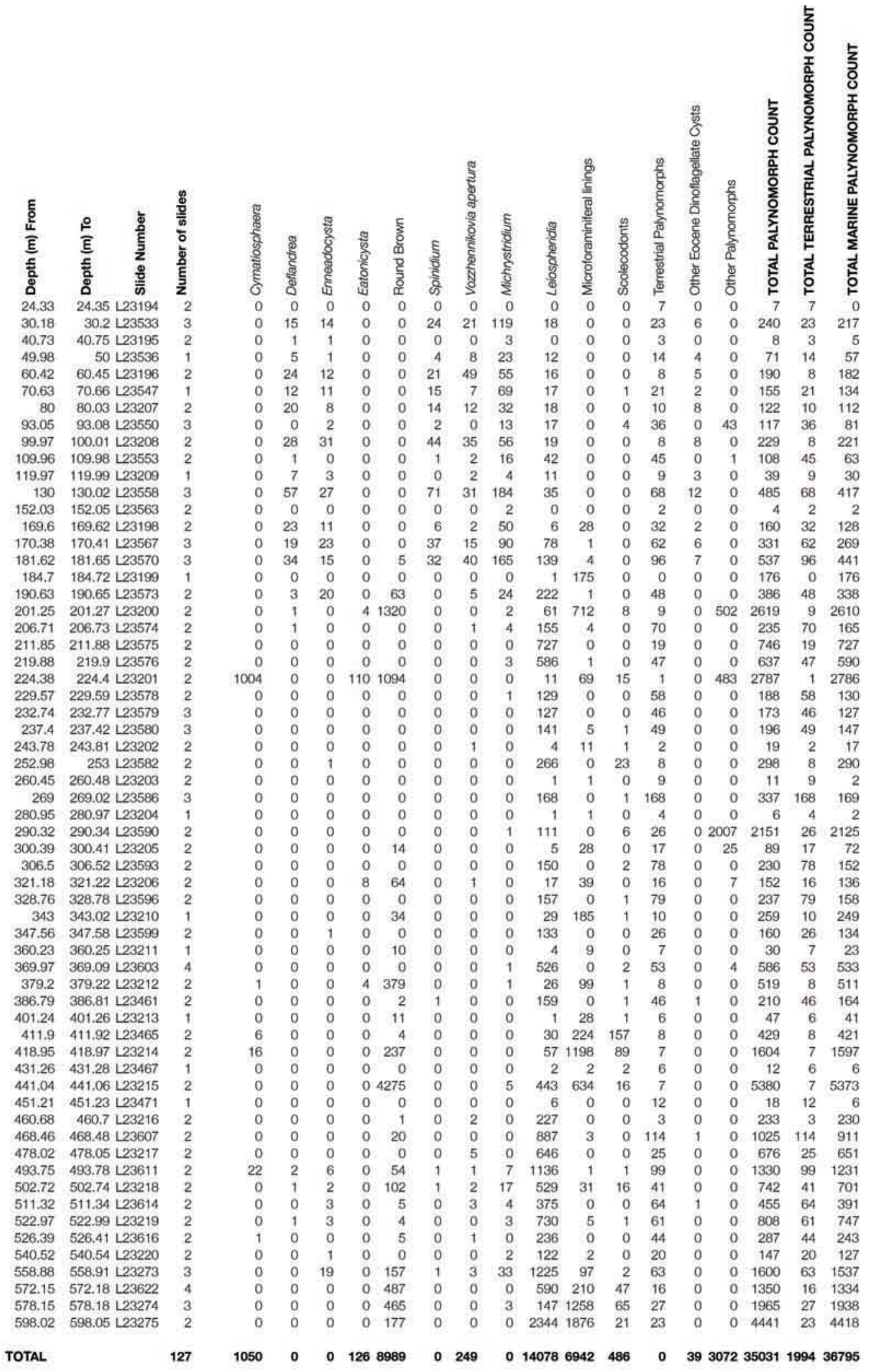

TABLE 01 - Raw palynomorph data from the AND-1B drill core showen as raw counts. 


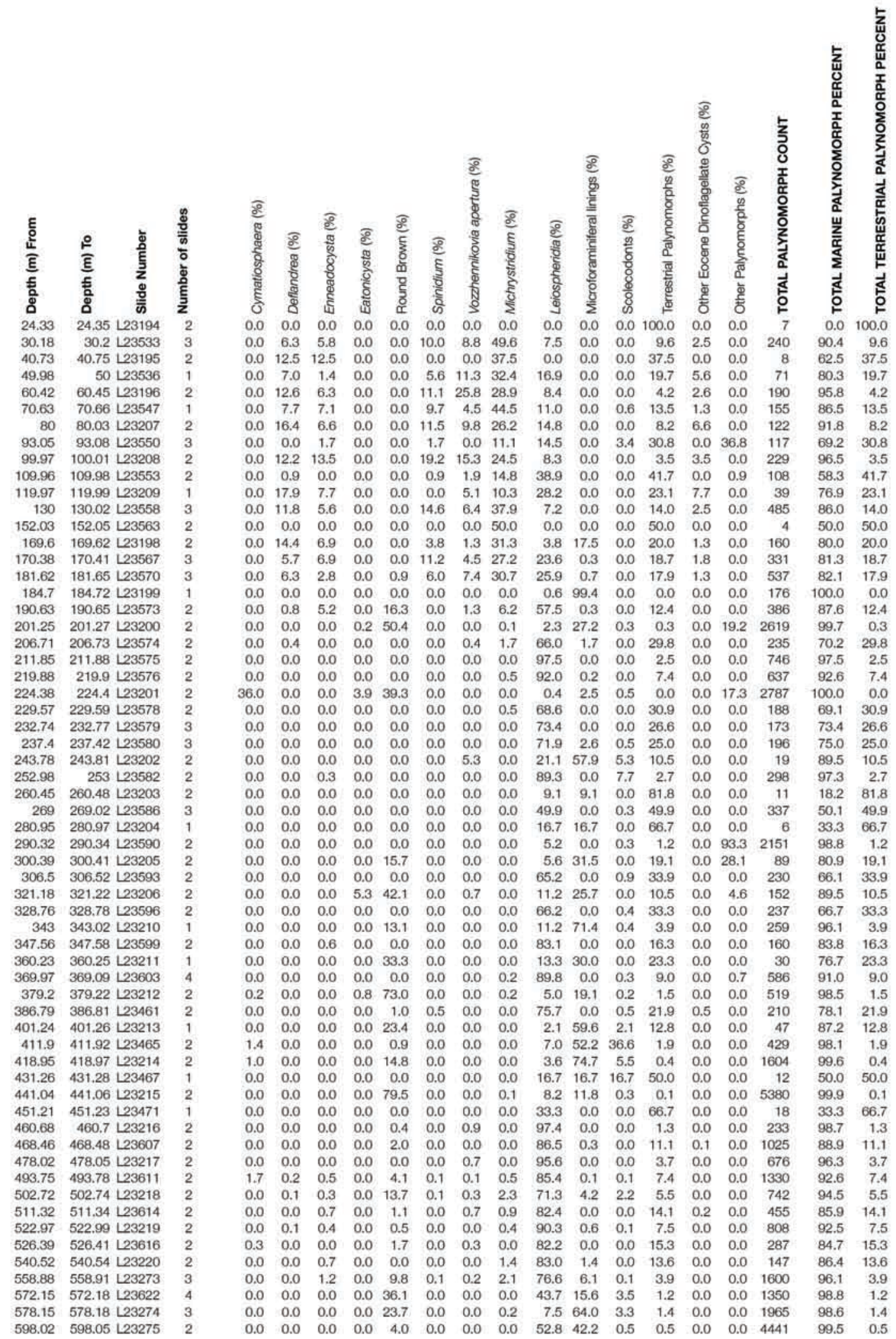

TABLE 02 - Raw palynomorph data from the AND-1B drill core represented as a percent of the total palynomorph data. 


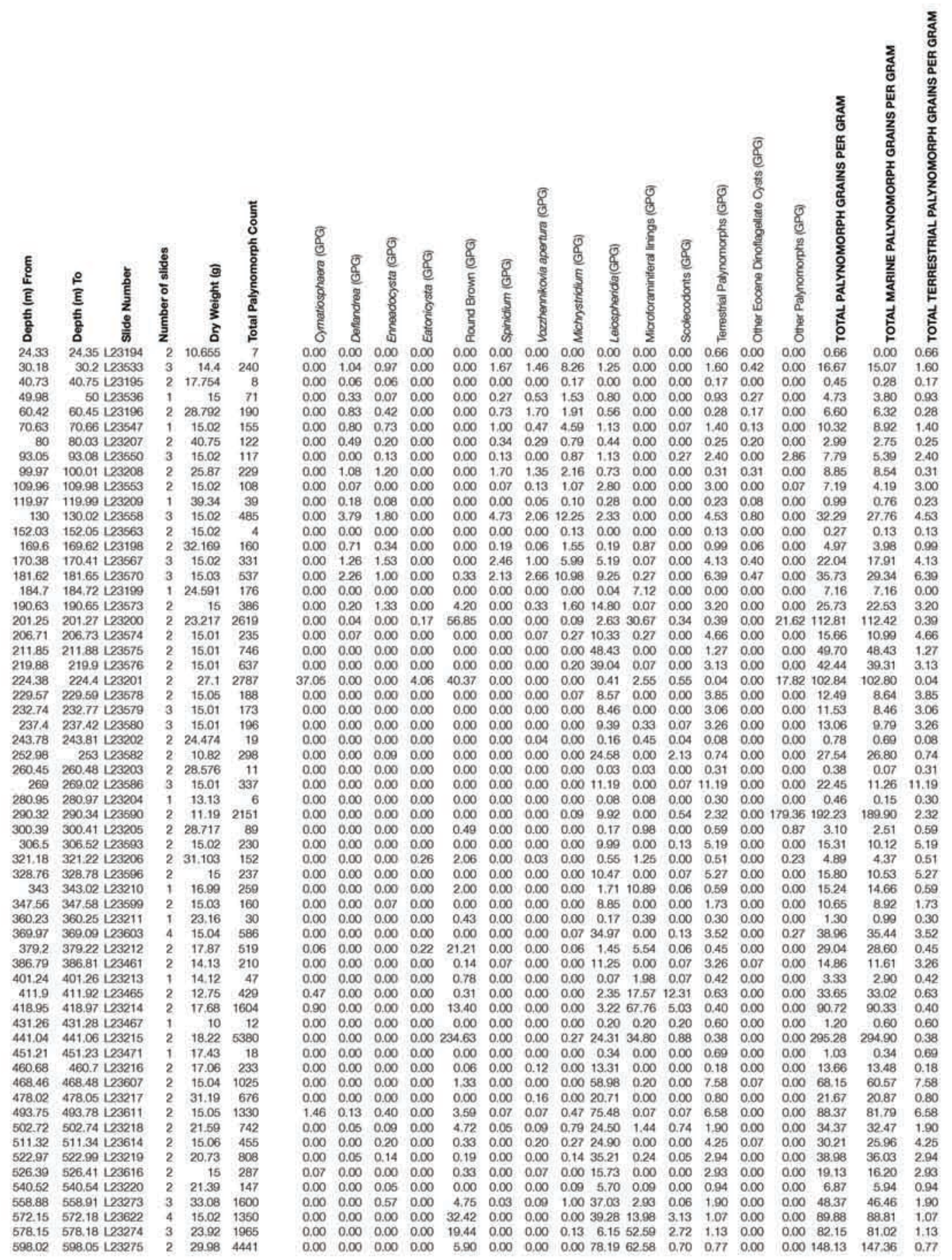

TABLE 03 - Raw palynomorph data from the AND-1B drill core represented as the number of palynomorph grains per gram of sediment ('grains per gram' or 'GPG'). 
APPENDIX B Palynomorph Study of ANDRILL Gravity Cores from McMurdo Sound, Antarctica.

Rory Mearns

NOTE: This was a preliminary study conducted in the buildup to the masters thesis study and should be treated as a separate work.

Results from this study are in the process of being rewritten for publishing. The conclusions remain the same. 
CONTENTS

\section{INTRODUCTION}

\section{PREVIOUS STUDY}

2.1 INTRODUCTION

2.2 WATER COLUMN PROPERTIES

2.2.1 COLUMN STRUCTURE

2.2.2 CURRENT OBSERVATIONS

2.3 CORES

2.3.1 TEXTURE

2.3.2 AGES

2.4 DIATOM STUDY SUMMARY

\section{PALYNOMORPH STUDY}

3.1 CORE SAMPLES

3.2 RESULTS

3.2.1 SITE 1

3.2.1.1 DINOFLAGELLATE CYSTS

3.2.1.2 ACRITARCHS

3.2.1.3 OTHER PALYNOMORPHS

3.2.2 SITE 2

3.2.2.1 DINOFLAGELLATE CYSTS

3.2.2.2 ACRITARCHS

3.2.2.3 OTHER PALYNOMORPHS

3.3 DISCUSSION

3.3.1 SITE 1

3.3.2 SITE 2

3.3.3 SITE COMPARISON

3.3.4 CORRELATION WITH DIATOM STUDY

\section{SUMMARY}

\section{REFERENCES}

\section{APPENDICES}

6.1 APPENDIX A - DINOFLAGELLATE SPECIES LIST

6.2 APPENDIX B - SPECIES COUNT DATA 


\section{INTRODUCTION}

This is a study of the palynomorphs from two ANDRILL cores taken beneath the McMurdo Ice Shelf during the Antarctic summer of 2002/03. The aim of this study is to identify any trends, patterns or events under the McMurdo Ice Shelf as recorded by the abundance and diversity of the palynomorphs, and to correlate the findings to other studies carried out on these two cores. 15 samples, over the two cores, were analysed using an optical microscope. Both marine and terrestrial palynomorphs were identified, counted, and photographed for future reference. Dinoflagellate cysts, acritarchs, zooplankton and terrestrial palynomorphs were observed in both of the cores. Overall abundances were very low except for the strong presence of zooplankton in one core with hundreds of grains per sample. The dinoflagellate cyst and acritarch specimens are mostly Eocene in age, predating the Pleistocene sediment they are found in by several tens of millions of years, indicating sediment reworking. Several trends in the palynomorph assemblage were found to correlate with changes in sediment characteristics as identified by Barrett (in Barrett et al.2005). The palynomorph samples of the two cores do not overlap in age hindering the possibility of making inferences about the high abundance of zooplankton in one core and their near absence in the other, despite their geographic separation of only $7 \mathrm{~km}$. The results from this study agree with existing findings from the previous studies in Barrett et al (2005), they also highlight areas that require further research i.e. the zooplankton abundance.

\section{PREVIOUS STUDY}

\subsection{INTRODUCTION}

During the Antarctic summer, from late December to early February 2003, samples of sediment were taken from beneath the McMurdo Ice Shelf in Windless Bight, south of Ross Island, to assess potential drill site locations for the ANDRILL deep drilling project, and to help understand current sedimentary processes under the ice shelf. The project sampled sediment at two sites situated 5 (Site 1), and 12 (Site 2) kilometers east in from the shelf edge near Scott Base, and South-West of Windless Bight. Site 1 is located $920 \mathrm{~m}$ below sea level (bsl), and the ice shelf thickness is $70.5 \mathrm{~m}$, while Site 2 is $923 \mathrm{mbsl}$ and the ice shelf thickness is $143.7 \mathrm{~m}$ (Table A1). 
Slte 1 - $5 \mathrm{~km}$ from edge of shelf

Position

Ice Shelf thickness

Datum - Ice Shelf surface

Firn-ice transition

Sea level depth

Sea floor depth by wire line

Site $2-12 \mathrm{~km}$ from edge of shelf

Position

Ice Shelf thickness

Datum - Ice Shelf Surface

Firn-ice Transition

Sea level depth

Sea floor depth by wire line
Jan 13 to 22

$77^{\circ} 53.308^{\prime} \mathrm{S} 167^{\circ} 05.067^{\prime} \mathrm{E}$

$70.5 \pm 0.1 \mathrm{~m}$

$0 \mathrm{~m}$

$27.0 \pm 0.5 \mathrm{~m}$

$17.3 \pm 0.2 \mathrm{~m}$

937 m (920 m bsl)

Jan 28 to Feb 2

$77^{\circ} 50.111^{\prime} \mathrm{S} 167^{\circ} 20.209^{\prime} \mathrm{E}$

$143.7 \pm 0.1 \mathrm{~m}$

$0 \mathrm{~m}$

$27.2 \pm 0.2 \mathrm{~m}$

$27.6 \mathrm{~m}$

$950.7 \mathrm{~m}(923 \mathrm{~m}$ bsl)

Table A1. Basic data for the two sites occupied in January 2003, on the McMurdo Ice Shelf in Windless Bight.

A hot water drill was used to penetrate the ice. The water column was sampled and sediment samples were taken from the sea floor using a gravity corer. A detailed summary can be found in the oceanography and sedimentation report of 2005 (Barrett et al.) This study concentrates on the palynomorph assemblages found at these two sites.

\subsection{WATER COLUMN PROPERTIES}

\subsubsection{COLUMN STRUCTURE}


There was a sharp in crease in salinity from 34.36 to $34.5 \mathrm{psu}, 50-90 \mathrm{~m}$ of water below the ice shelf at Site 1. Following this was a gradual increase in salinity continuing to the sea floor where it measured around 34.71 psu.

The first $60-100 \mathrm{~m}$ of the water column exhibited the warmest temperatures of $-1.915^{\circ} \mathrm{C}$, from 111 to $275 \mathrm{~m}$ the coldest waters were encountered reaching $-1.936^{\circ} \mathrm{C}$. Below this the waters gradually warmed to a stable temperature of around $-1.916^{\circ} \mathrm{C}$ at around $500-660 \mathrm{~m}$, which it remains at to the sea floor.

Site 2 exhibited the same basic structure as seen at Site 1 although slight differences are observed in the defined water structure zones. These differences and the slight variability observed over the span of a diurnal tidal cycle are outlined and discussed in the full report (Barrett et al,2005).

\subsubsection{CURRENT OBSERVATIONS}

After the water column structure was sampled, equipment was lowered to measure current properties over a time period of 87 hours (Site 1) and 48 hours (Site 2). At both sites there is a strong correlation between current velocity and tidal cycle. Fast easterly flows were observed on the flood tide with slower south to west flows on the ebb tide, and this was observed throughout the water column. The net flow is noted to be from McMurdo Sound, to the east into Windless Bight.

\subsection{CORES}

Using a gravity corer 6 cores were taken at Site 1 . The core used for this study is core number 4 , the longest of the 6 that were recovered, measuring $61 \mathrm{~cm}$ (referred to as Site 1 in text). At Site 2 only 4 cores were taken and core number 4 is used in this study, also measuring $61 \mathrm{~cm}$ (referred to as Site 2 in text). Taken from Barrett et al. (2005) the core is described as follows (a detailed lithologic description can be found in the original study): 
Site 1 is divided into 7 lithilogical units.

Unit $1(0-8.5 \mathrm{~cm})$ is a soft to firm fine sandy mud with minor coarse sand. The upper 1-

$2 \mathrm{~cm}$ contained small pebbles up to $16 \mathrm{~mm}$ long, mostly basaltic. A small biogenic fraction included sponge spicules and diatoms.

Unit $2(8.5-11 \mathrm{~cm})$ is a firm bioturbated mud with less than $10 \%$ sand.

Unit $3(11-16 \mathrm{~cm})$ is a very fine sandy mud with a few sponge spicules and diatoms. It also contains a small mollusk, a worm tube, and several foraminifera.

Unit $4(16-24 \mathrm{~cm})$ is a firm mud with a few diatoms and rare forams.

Unit $5(24-31 \mathrm{~cm})$ is a dark interval of soft muddy fine to very fine sand. $\mathrm{mm}$ scale lamination. Few diatoms observed and a sharp lower contact with load features.

Unit $6(31-36 \mathrm{~cm})$ is a firm mud with coarse sand grains, and a few small pebbles. It is moderately bioturbated and has a few diatom fragments.

Unit $7(36-61 \mathrm{~cm})$ Is a firm, slightly sandy mud with sparse scattered clasts. The clasts, typically $10 \mathrm{~mm}$ but up to $48 \mathrm{~mm}$ long, are both angular and sub rounded in shape and are all basic volcanic in composition. A few are striated.

Site 2 is divided into 4 lithological units.

Unit $1(0-3 \mathrm{~cm})$ is a soft, very sandy mud with a few small pebbles up to $16 \mathrm{~mm}$ in length. Similar to the surface layer in Site 1.

Unit $2(3-16 \mathrm{~cm})$ is a firm, sandy mud with little coarse sand and rare pebbles and strongly bioturbated.

Unit $3(16-59 \mathrm{~cm})$ is a firm, slightly sandy mud with rare coarse sand above $20 \mathrm{~cm}$ and below $42 \mathrm{~cm}$.

Unit 4 $(59-61 \mathrm{~cm})$ is a slightly sandy mud with a little fine to coarse sand and rare clasts up to $7 \mathrm{~mm}$ long all of which are angular to sub-angular and basic volcanic.

\subsubsection{TEXTURE}

Unit 7 from Site 1 (Figure 2) has an extreme textural range suggesting this unit is of glacial origin representing a time when the Ross Ice Shelf was grounded at a deeper level than it is found today (Barrett et al.). An unusual feature observed at Site 1 is lithological Unit 5, a $5 \mathrm{~cm}$, well-sorted fine sand. Barrett (2005) noted that it is possible sand could have been blown onto the shelf ice in an unusual storm event, and then moved down through the ice until it was released. 
Alternatively it may have been transported in a sediment gravity flow. This feature is not exhibited at Site 2 and thus far remains unexplained.

The sediment texture exhibited at Site 2 is typical of a quieter environment as expected from its location further landward under the ice shelf. A feature observed at both sites is the presence of coarse sand and gravel in the top few centimeters of the core (Unit 1 of Site $1 \& 2$ ). Barrett (2005) notes iceberg transportation is an unlikely explanation as the McMurdo Ice Shelf edge would need to retreat at least $12 \mathrm{~km}$ to expose the sites, and such an event has not been identified in the last 20,000 years Kellogg et al. 1996 (as cited in Barrett et al. 2005). An alternative explanation is that the ice shelf itself carried these sediments here.

\subsubsection{AGES}

${ }^{14} \mathrm{C}$ ages were obtained from the analysis of organic carbon in acid insoluble organic (AIO) residues from 10 samples at Site 1 and Site 2. Several factors needed to be accounted for in correcting and calibrating the $\mathrm{AIO}{ }^{14} \mathrm{C}$ ages, some unique to the region. These are discussed in full in the original report (Barret et al.2005)

The oldest unit identified was lithological Unit 7 from Site 1, a $30 \mathrm{~cm}$ thick diamicton that forms the lower portion of the core. This unit is dated between 21,800 and 25,700 years before present and this coincides with the Last Glacial Maximum. Above this unit age determinations predict a constant rate of sedimentation of $0.01 \mathrm{~mm} /$ year for Site 1 and $0.05 \mathrm{~mm} /$ year for Site 2 .

\subsection{DIATOM STUDY SUMMARY}

Harper (in Barrett et al) recognised three diatom units in the cores from Site 1 and Site 2, illustrated in blue in figure 2 .

Unit A, present at both Site $1(0-5 \mathrm{~cm})$ and Site $2(0-58 \mathrm{~cm})$, is comprised of more than $50 \%$ contemporary Ross Sea species. The majority of the diatoms in this unit are believed to have come from McMurdo Sound, carried by tidal currents past Hut Point and into the deeper, slower moving waters of Windless Bight where they have 
been deposited (figure 1). Some glacial input was also observed in this unit, defined as broken diatoms and fragments of diatoms fractured during glacial reworking.

Unit B is present at Site $1(4-36 \mathrm{~cm})$ and at the base of the core at Site $2(58-61 \mathrm{~cm})$. It is defined as having a total of $25-50 \%$ contemporary Ross Sea species and an increase in glacially derived diatom fragments compared to Unit A.

Unit C, present only at the core base at Site $1(36-61 \mathrm{~cm})$. This unit is characterised by having less than $20 \%$ contemporary Ross Sea species and containing a very high proportion of glacially derived fragments. This unit coincides with the diamict unit observed in the core (Lithological Unit $7-36-61 \mathrm{~cm}$ ). Older, non-contemporary Ross Sea species observed in this unit are believed to have been sourced from higher topography to the south. When the grounded ice passed over this higher topography, the older species were entrained and then deposited in Windless Bight. 


\section{PALYNOMORPH STUDY}

\subsection{CORE SAMPLES}

A total of 15 samples were taken for this study at irregularly spaced intervals. 8 were taken from Site 1 , Core 4 starting at a depth of $8.5 \mathrm{~cm}$ below the core top and ending at $54 \mathrm{~cm}$ below the core top. 7 were taken from Site 2, Core 4, the sampling started at $8.5 \mathrm{~cm}$ below the core top and finished at $53.5 \mathrm{~cm}$ below the core top. Exact sample locations are noted in Table A2 and are also illustrated in Figures 3 and 4.

\begin{tabular}{lll}
\hline Core & Sample & Depth cm \\
\hline HWD03-1 & L22555 & 8.5 \\
& L22557 & 13 \\
& L22558 & $16.5-17.5$ \\
& L22560 & $22.5-23.5$ \\
& L22562 & $31.5-32.5$ \\
& L22564 & $34-35$ \\
& L22566 & 44.5 \\
& L22569 & 54 \\
& & \\
HWD03-2 & L22556 & $8.5-9.5$ \\
& L22559 & $17.5-19$ \\
& L22561 & $22-24$ \\
& L22563 & 33.5 \\
& L22565 & 39 \\
& L22567 & 47 \\
& L22568 & 53.5 \\
\hline
\end{tabular}

Table A2 Sample locations down core at site $1 \& 2$. 


\subsection{RESULTS}

\subsubsection{SITE 1}

A dinoflagellate species list is located in appendix A of this study. The following definitions are used for describing abundances in this study:

Very Low Abundance $1-2$ (total count)

Low Abundance $\quad 3-4$

Moderate Abundance $5+$

Working from the top of the core to the bottom, several observations can be made about the palynomorphs despite their overall low abundance (Figure 3). Most identified palynomorph species appear in low abundance in the first sample taken at $8.5 \mathrm{~cm}$. A drop in abundance and diversity is observed in the next sample before a low to moderate abundance and diversity is observed between 20 and $35 \mathrm{~cm}$ from the core top. Below $35 \mathrm{~cm}$ abundance steadily drops in nearly every species to zero by the last sample taken at $54 \mathrm{~cm}$ from the core top.

\subsubsection{DINOFLAGELLATE CYSTS}

A total of 10 different dinocyst species are identified throughout the whole core. 7 different dinocyst species are identified in the first sample (Sample number: L22555, $8.5 \mathrm{~cm}$ from core top), most having a very-low to low abundance: Deflandrea antarctica, Deflandrea flounderensis, Enneadocystapartridgei, Hystrchosphaeridium sp, Spinidinium colemanii, Spinidinium macmurdoense, and Vozzhennikovia apertura. The most abundant species in this sample is Vozzhennikovia apertura, with a total count of 6 grains followed by Deflandrea antarctica, with a count of 5 grains.

The second sample (L22557), taken at $13 \mathrm{~cm}$ from the core top, has reduced abundances and a lower diversity. A total of 3 species are identified: Deflandrea antarctica, Hystrichosphaeridium $s p$ and Vozzhennikovia apertura. Deflandrea antarctica is the most abundant species with only 3 grains counted.

Over the next $22 \mathrm{~cm}$ of core, down to $35 \mathrm{~cm}$ from the core top, there is an observed increase in both abundance and diversity with $5 \& 6$ different species being identified in the samples taken 
from 31.5-32.5 \& 34-35 cm respectively (L22562 \& L22564). Abundance of Spinidium increases, peaks and then decreases over this $22 \mathrm{~cm}$ section with the final Spinidium grain being identified in the $34-35 \mathrm{~cm}$ sample. The two most abundant species over this section are Deflandrea antarctica and Vozzhennikovia apertura. The abundance of Deflandrea antarctica increases steadily from the 2 nd sample and peaks at the $34-35 \mathrm{~cm}$ sample where 9 specimens are identified. The abundance of Vozzhennikovia apertura increases a little more rapidly from the 2nd sample to peak at 12 grains at $31.5-32.5 \mathrm{~cm}$. Three of the species identified are only observed over this $22 \mathrm{~cm}$ section and their abundances are very low: Alterbidinium asymmetricum, ?Impagidinium victorianum and Turbiosphaera filosa (of which there is only 1 fragment identified. Plate 3, image 1).

Only two samples were taken below the $31.5-32.5 \mathrm{~cm}$ sample. Abundance and diversity drops rapidly until the last sample in which only 2 Vozzhennikovia apertura grains are counted.

\subsubsection{ACRITARCHS}

Two Acritarch genera are observed at site 1,Micrhystridium spp. and Leiospheridia spp. The abundance pattern observed in the dinocyst assemblage is also seen in the abundance of the acritarchs. In the first sample there are more specimens than in the second a total of 3 Micrhystridium and 4 Leiospheridia. Only 2 Leiospheridia are seen in the second sample and they are not observed again until the second to last sample at $44.5 \mathrm{~cm}$ (L22566) in which there is only 1 grain counted.

An almost steady rise in the abundance of Micrhystridium from the second sample to where they peak at 10 grains from the $31.5-32.5 \mathrm{~cm}$ sample. 9 specimens are observed at the $34-35 \mathrm{~cm}$ sample below which there is a rapid decline to 3 grains in the second to last sample $(44.5 \mathrm{~cm})$. No Acritarchs are observed in the final sample at $54 \mathrm{~cm}$ (L22569).

\subsubsection{OTHER PALYNOMORPHS}


Other palynomorphs observed at site 1 include Zooplankton (as identified from Storkey 2006), of which only 2 whole grains and 2 fragments are observed in the first $24 \mathrm{~cm}$ of the core. One microforaminiferal lining is observed in the second to last sample at $44.5 \mathrm{~cm}$.

A terrestrial component is also observed throughout the core. The top sample contains the highest terrestrial component with a count of 20 specimens. The second sample down contains the lowest count observed with a total of 2 specimens identified. The remaining samples all have between 3 and 9 specimens with most containing 7 , including the bottom sample which has no other identifiable palynomorph other than 2 Vozzhennikovia apertura grains.

\subsubsection{SITE 2}

Site 2 , as illustrated in figure 4, contains notably less dinoflagellate cysts, acritarchs, microforaminiferal linings, and terrestrial content. It does however contain a large quantity of zooplankton with numbers in the hundreds per sample. A spike in palynomorph abundance is observed in the second to bottom sample taken at $47 \mathrm{~cm}$ 's from the core top (Note that the horizontal species abundance scales in figure 4 differs not only from figure 3, but within itself as denoted by the change in color).

\subsubsection{DINOFLAGELLATE CYSTS}

Dinoflagellate cysts are very low to low in abundance throughout this core with 2 Deflandrea antarctica grains in each of the last 3 samples taken 39,47 , and $53.5 \mathrm{~cm}$ from the core top (samples L22565, L22567, and L22568), a single Deflandrea flounderensis grain in the first sample taken from $8.5-9.5 \mathrm{~cm}$ (L22556), and a few single Spinidium macmurdoense grain in the final few samples.

Vozzhennikovia apertura appears in every sample down core, sometimes only represented by a single grain. The highest quantity of Vozzhennikovia apertura observed is 5 grains in the 2 nd to last sample. 


\subsubsection{ACRITARCHS}

Similar to the core at Site 1, the only identified Acritarch genera are Micrhystridium and Leiospheridia.

Micrhystridium does not exhibit the same quantities as seen at Site 1 with only a few single grains scattered throughout the core. The only sample that contains more than one grain of Micrhystridium is the 2 nd to last sample down core at $47 \mathrm{~cm}$ from the core top, which contains 3 grains.

Leiospheridia has a stronger presence in this core than at Site 1. Although none are identified in the $3 \mathrm{rd}$ sample (L22561, taken at $22-24 \mathrm{~cm}$ ), other samples contain between 1 and 3 grains and the 2 nd to last sample contains 8 grains.

\subsubsection{OTHER PALYNOMORPHS}

Only 2 Microforaminiferal linings are observed in the whole core and they are both in the last sample taken from $53.5 \mathrm{~cm}$.

The terrestrial component peaks in abundance in the first sample with 4 grains before dropping to 1 then 0 grains in the $3 \mathrm{rd}$ and 4 th samples from the top respectively. Another 2 terrestrial grains are observed in the 2 nd to last sample, and 1 observed in the last sample of the core.

Zooplankton and zooplankton fragments have a strong presence throughout the core at Site 2 unlike the core at Site 1 where they are nearly non-existent. The number of zooplankton observed in the first two thirds of the core remains fairly constant with numbers of whole specimens ranging from 131 to 173 and fragment counts ranging from 132 to 282 . In the 3 rd to bottom sample the number of whole specimens and fragments drop by around half to numbers of 78 and 84 respectively. They then increase in quantity again in the 2 nd to last sample with whole specimens numbering 130, and fragments 189. In the last sample the numbers of whole specimens and fragments again drops, this time to their lowest numbers of 29 and 67 respectively. 


\subsection{DISCUSSION}

It is apparent when looking at the species range charts, (figures $3 \& 4$ ) and then comparing the age range in which each species is found (appendix A) to the radio carbon dates on figures 3 and 4, that the palynomorph content at Site 1 and Site 2 is largely reworked from Eocene deposits (with particular reference to the dinocysts).

\subsubsection{SITE 1}

Site 1 can be broken into 4 units based primarily on palynomorph abundance with influence of diversity. These can be seen as horizontal red lines in figure 2. The sampling resolution of this study is not high enough to assess how tightly the lithology and palynomorph zones are related, but palynomorph-lithology changes do suggest a palynomorph-lithology relationship. The evidence of palynomorph reworking supports this relationship. As sediment source changes, so do the palynomorph assemblages being reworked into the more recent sediment. Because of these observations, unit divisions used here are based on lithological unit divisions.

The oldest unit is palynomorph Unit 4 (35 cm from the core top onward). Dated between 22,000 and 26,000 years before present (ybp) palynomorph Unit 4 contains two palynomorph samples (L22566 \& L22569) and coincides with the diamicton - lithological Unit 7. In the samples from Unit 4 the low palynomorph abundance suggests that the sediment that this unit is sourced from a different location than all other units. The time of deposition of this unit was during the Last Glacial Maximum (LGM) this may explain the apparent change in where the sediment was sourced and/or the way in which it was deposited.

Palynomorph Unit 3 ( $15-35 \mathrm{~cm}$ from the core top) coincides with lithological units $4-6$ and contains 4 palynomorph samples (L22558, L22560, L22562 and L22564). In this unit, abundance and diversity is low to moderate. This unit represents a stable ice shelf condition under which these reworked sediments were deposited. Lithological unit 5 is not sampled in the palynomorph study so is not divided into its own separate palynomorph unit. However if it were to be sampled it may have a significantly different assemblage in terms of both palynomorph abundance and diversity when compared to the surrounding samples. The reason for this is that Lithological Unit 5 is an unusual unit as mentioned by Barrett in the sediment study of Barrett $e t$ 
al (2005), and by McKay (2005) in the petrographic study of Barrett et al (2005). A change in sedimentation such as in the scenarios proposed to explain this unit (wind blown sediment and sediment flow) would have an effect on the palynomorph source and deposition.

Palynomorph Unit 2 (10.5 - $15 \mathrm{~cm}$ from the core top) is solely comprised of Lithological Unit 3 and consists of a single palynomorph sample. A drop in abundance and diversity is observed in the dinoflagellates, acritarchs and terrestrial palynomorphs. Because it has a higher sand content than its surrounding lithological units, the low palynomorph abundance and diversity could possibly be attributed to an event similar to the one that caused the high sand content of Lithological Unit 5 as discussed in the sedimentology section of this study. Only further sampling could make interpretations easier.

Palynomorph Unit 1 (8.5 $-10.5 \mathrm{~cm}$ from the core top) coincides with lithological Unit 2 and is similar in abundance and diversity to palynomorph Unit 3. For this reason it can be considered a product of similar processes that formed palynomorph Unit 3.

\subsubsection{SITE 2}

(Figure 4) There are two features of Site 2. The first, and less pronounced of the two, is the slight increase in Palynomorph content in the 2 nd to last sample. There is no obvious explanation for this in the stratigraphic study, nor is there any correlation to any obvious trends in the diatom study. For now, this increase can only be described as an increase in the amount of palynomorphs deposited.

The second notable feature of Site 2 is the abundance of zooplankton (note the different horizontal scale used in representing the numbers zooplankton in figure 4). At Site 1 only two whole zooplankton samples were observed in the entire core sample set, along with two identified fragments. The record at Site 2 tells a different story despite being separated by only 7 $\mathrm{km}$. The number of whole specimens at site 2 begins with a high of 173 specimens in the first sample and fluctuates steadily down core until it gets to the lowest point of 29 specimens in the last sample. The Number of zooplankton fragments down core is generally higher than the number of whole specimens observed (often nearly double the count), but the same pattern is roughly mirrored. 


\subsubsection{SITE COMPARISON}

Working from the carbon ages there is a small overlap between the two cores. The youngest palynomorph sample at Site 1 is roughly the same age as the oldest sample at Site 2. Bearing in mind the heavy decline in both zooplankton specimen and fragment abundance towards the core bottom at Site 2, there is little confidence in comparing the two sites.

If further sampling were to identify that the abundance of zooplankton were in fact a feature of only Site 2 then inferences could be made about past conditions in the area (in the past 2,000 15,000 years) that could have varied enough to greatly prohibit and/or promote zooplankton growth on the kilometer scale. One way to explain this would be ice shelf coverage. If zooplankton are able to live under the ice shelf, this may give some indication of conditions under the ice shelf such as current flow or even a discrete local grounding. If the zooplankton are unable to survive under the ice shelf then this indicates at the very least a partial, local break up of the ice shelf.

If there are zooplankton present at Site 1 but they weren't sampled because of the lack of a sufficient crossover between the two core, all that could be said is that the zooplankton were only a recent phenomenon being present here only in the last 12,000 years. If this is the case inferences could be made about the cause of the proliferation of zooplankton $\sim 12,000$ years ago. It may represent major changes in under ice sheet hydrodynamics caused by a change in the ice sheet morphology itself.

The lack of zooplankton at Site 1 compared to the presence they have throughout the core at Site 2 , along with little core crossover make it difficult to infer local or regional effects or processes that could explain the zooplankton. Further study would be needed to reveal their full extent in the McMurdo Sound area. 


\subsubsection{CORRELATION WITH DIATOM STUDY}

Harper (in Barrett et al. 2005) identified 3 distinct diatom units as discussed in the diatom section of this study these unit boundaries are illustrated in figure 3 for Site 1 . The boundary between Unit A and Unit B falls outside the zone sampled for the palynomorph study. It sits 5 $\mathrm{cm}$ down from the core top while the sampling for this study begins $8.5 \mathrm{~cm}$ down from the core top. The boundary between Unit B and Unit C lies well within the sampled area of this study and correlates well with changes in the sedimentary $\log$ (see graphic $\log$ in figures $3 \& 4$ ). It also correlates considerably well with changes observed in palynomorph abundance and diversity, the boundary between palynomorph Units $3 \& 4$.

As mentioned above the sampling for this study from Site 1 starts $3.5 \mathrm{~cm}$ below the identified boundary between diatom Unit A and Unit B, so direct observations cannot be made. Lower down the core at around $35 \mathrm{~cm}$ is an observable correlation. At this point the sedimentary lithology changes from mud, with units containing sand, to diamicton. The change from diatom Unit B to Unit C is here also, denoted in Harper's study by a change from $25-50 \%$ contemporary Ross Sea species (Unit B) to having less than $20 \%$ contemporary Ross Sea species (Unit C) and a higher fragmentation of diatom content. Observed in this study is a high abundance of palynomorphs about $2 \mathrm{~cm}$ before the diatom and sedimentary boundary to very low abundances and diversity in the next sample, $10 \mathrm{~cm}$ down. As discussed above, this boundary is most likely to reflect a change in where the sediment is being sourced, and a grounding of the ice shelf in the area of this study.

The diatom boundaries are not illustrated in figure 4 for Site 2 as the palynomorph sampling does not cross a diatom boundary.

\section{SUMMARY}

The investigations made into palynomorph abundance and diversity resulted in several interesting observations. Firstly, it is apparent that the bulk the dinoflagellate cysts and acritarchs are the product of reworking of older sediments as their range (typically from the Eocene) precedes the estimated age of the sediment they currently reside in by tens of millions of years. The second observation, which also suggests that the palynomorphs were deposited by 
reworked sediments, is that changes in lithology type are reflected by changes in palynomorph abundance and diversity. Another major observation is the high abundance of zooplankton found in the core at Site 2. The lack of core crossover in the palynomorph samples creates difficulties for inferring the geographic extent to the zooplankton, both horizontally and vertically through the sediment. The entire length of Core 4 from Site 2 that was sampled for the palynomorph study postdates the length sampled from Core 4 at Site 1 . Because of this it is unknown whether the zooplankton presence ends in vertical distribution at the base of Core 4 Site 2 , or whether there are differences in the habitat or mode of deposition between the two site locations separated by $7 \mathrm{~km}$. Further study is required to completely understand the processes acting on the zooplankton. This study also reveals other areas of interest such as lithological Unit 5 and lithological Unit 3 from Site 1, where further study could reveal more details about their geological history. 


\section{REFERENCES}

Barrett, P.J., Carter, L., Dunbar, G.B., Dunker, E., Giorgetti, G., Harper, M.A., McKay, R.M., Niessen, F., Nixdorf, U., Pyne, A.R., Riesselmann, C., Robinson N., Hollis, C., and Strong, P. 2005. Oceanography and sedimentation beneath the McMurdo Ice Shelf in Windless Bight, Antarctica. Antarctic Data Series, Antarctic Research Centre, Victoria University of Wellington. 100pp.

Kellogg, T.B., Hughes, T., and Kellogg, D.E., 1996. Late Pleistocene interactions of East and West Antarctic ice-flow regimes: evidence from the McMurdo Ice Shelf.Journal of Glaciology 42, 486-500.

Lentin, J.K., \& Williams, G.L. (1976). A monograph of fossil peridinioid dinoflagellate cysts. Bedford Institute of Oceanography, Report Series, no.BI-R-75-16, 237.

Levy, R. H., and Harwood D. M.2000. Tertiary marine palynomorphs from the McMurdo Sound erratics, Antarctica, in Paleobiology and Paleoenvironments of Eocene Rocks, McMurdo Sound, East Antarctica, Antarct. Res. Ser., vol.76, edited by J. D. Stilwell and R. M. Feldmann, pp. 183-242, AGU, Washington, D. C.

Storkey, C.A. 2006. Distribution of Marine Palynomorphs in Surface Sediments, Prydz Bay, Antarctica. Unpublished masters thesis, Victoria University of Wellington, Wellington, New Zealand.

Wilson, G.J., and Clowes, C.D. 1980. A Concise Catalogue of Organic-Walled Fossil Dinoflagellate Genera. New Zealand Geological Survey. Report 92. Department of Scientific and Industrial Research, New Zealand. 


\section{APPENDICES}

\subsection{APPENDIX A - DINOFLAGELLATE SPECIES LIST}

Dinoflagellate species as identified in Levy and Harwood 2000, Wilson \& Clowes 1980 and Lentin \& Williams 1976

Alterbidinum (Plate 1,\#: $1 \& 2$ )

Comments: Short, single visible antapical horn; relatively small and circumcavate with a small space separating the two walls.

Range: Unknown

Alterbidinum asymmetricum. (Plate 1,\#:3)

Deflandrea (Plate 1, \#: 4, 5, 6,7 \&8)

Comments: Relatively large size; circumcavate cysts (sometimes missing outer wall in part or entirely); broad hexa archeopyle; smooth to very granular endocyst surface; often distinct cingulum and sometimes distinct tabulation.

Range: ?Eocene.

Deflandrea antarctica (Plate 1, \#: 5,6\&7)

Deflandreaflounderensis (Plate 1,\# 8)

Comments: Smooth endocyst; smaller than $D$. antarctica; thin walled endocyst.

Enneadocysta partridgei. (Plate 1,\#:9)

Comments: Lenticular shape; large solid processes and distal bifurcation of processes.

Range: Bartonian-Rupelian

Hystrichosphaeridiumsp. (Plate 2,\#: 1 \& 2)

Comments: Hollow processes and often damage in these samples with broken or missing processes.

Range: Unknown 
?Impagidinium victorianum. (Plate 2,\#': 3 \& 4)

Comments: The single specimen found in this study is very weathered and damaged but has a septa structure that can be observed.

Range: Late Eocene

Spinidinium. (Plate 2, \#: 5, 6, 7, 8 \&9)

Comments: Differing from Vozzhennikovia by having ornamentation arranged in a penitabular rows and/or intratabular clusters. Cingulum often observed.

Spinidinium colemanii. (Plate 2,\#:7)

Comments: Longer ornamentation than $S$. macmurdoensis.

Range: Unknown

Spinidinium macmurdoensis. (Plate 2, \#: 8 \& 9)

Comments: Small penitabular ornamentation.

Range: Early Tertiary

Turbiosphaera filosa. (Plate 3, \#: 1)

Comments: Only a single specimen fragment observed. A single wide, flat processes was observed on this fragment.

Range: Paleocene - Oligocene

Vozzhennikovia apertura. (Plate $3, \#: 2,3 \& 4$ )

Comments: Non-tabular ornamentation. Cingulum and/or archeopyle observed in most specimens.

Range: Paleocene - Oligocene 
APPENDIX B - SPECIES COUNT DATA

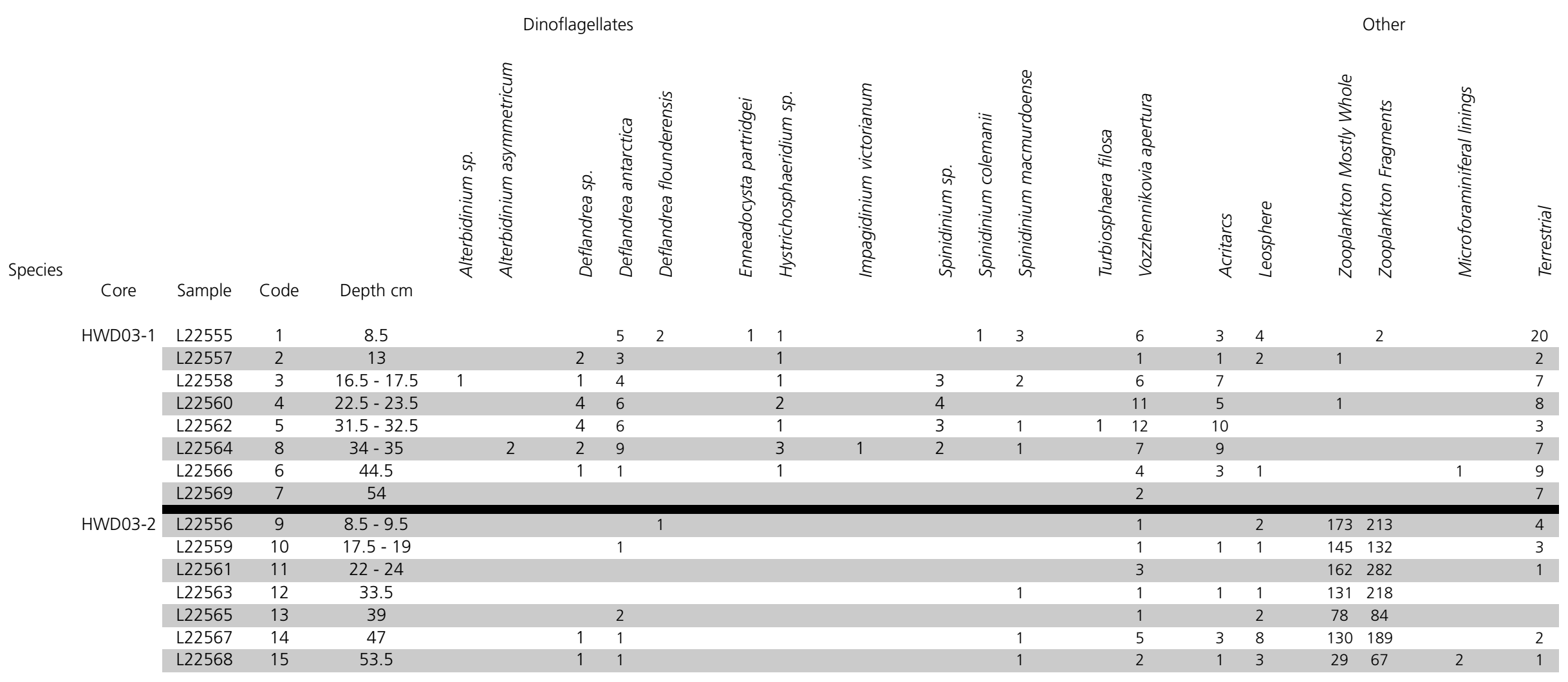




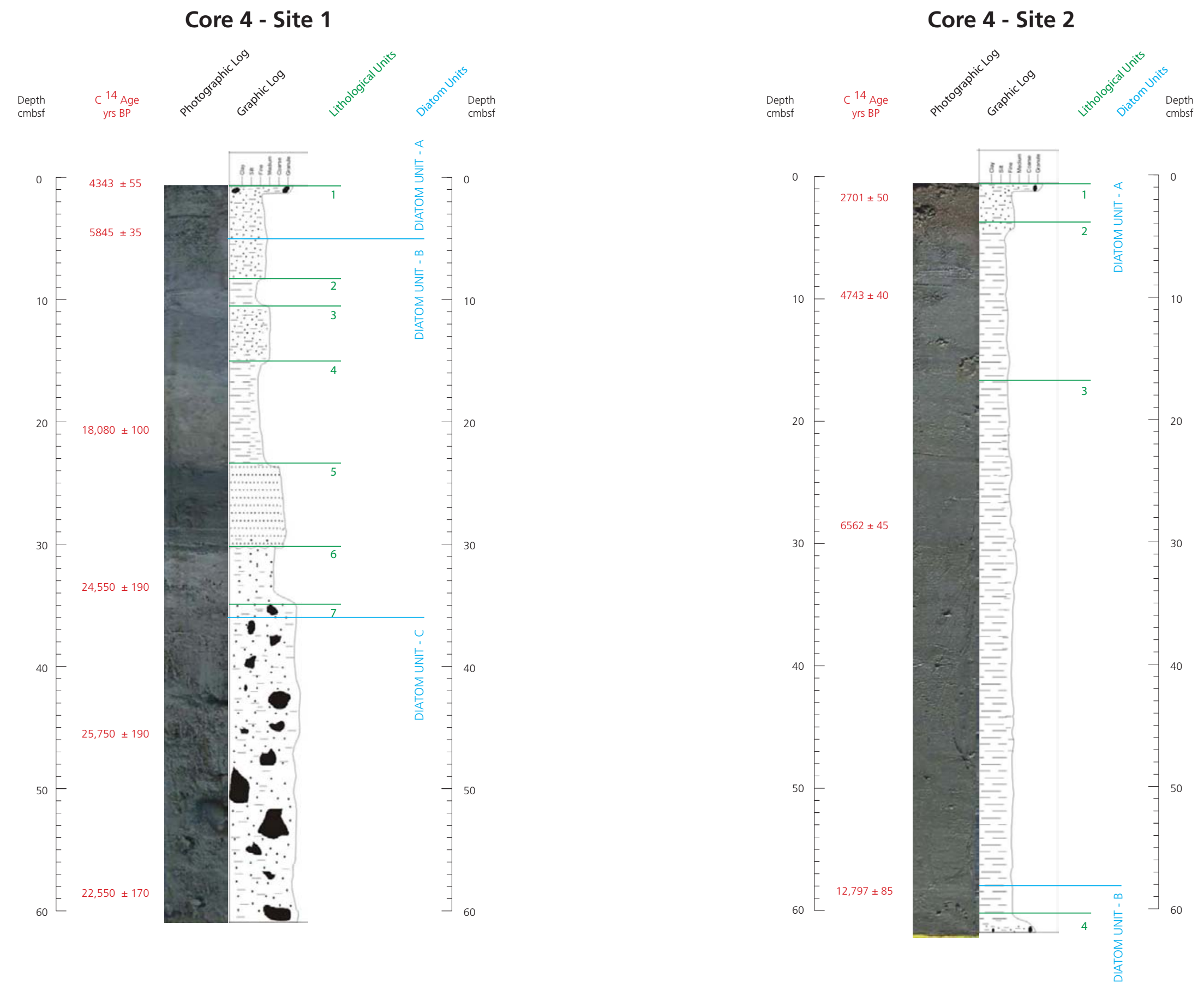

Figure 1. Detailed core information from Core 4 at Site 1, and Core 4 at Site 2. Obtained from studies in the 2005 report (Barret et al) Refer to text. 


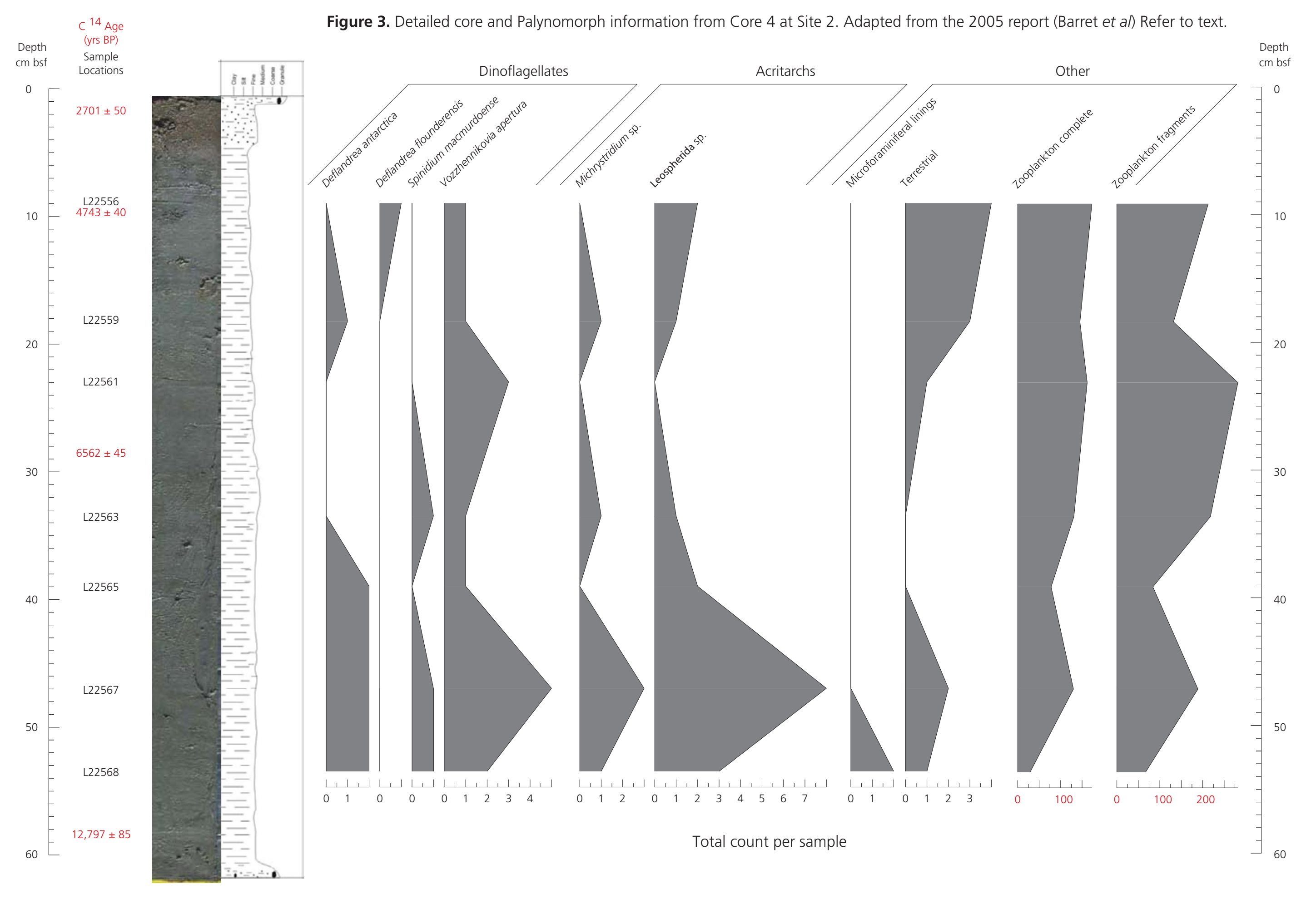



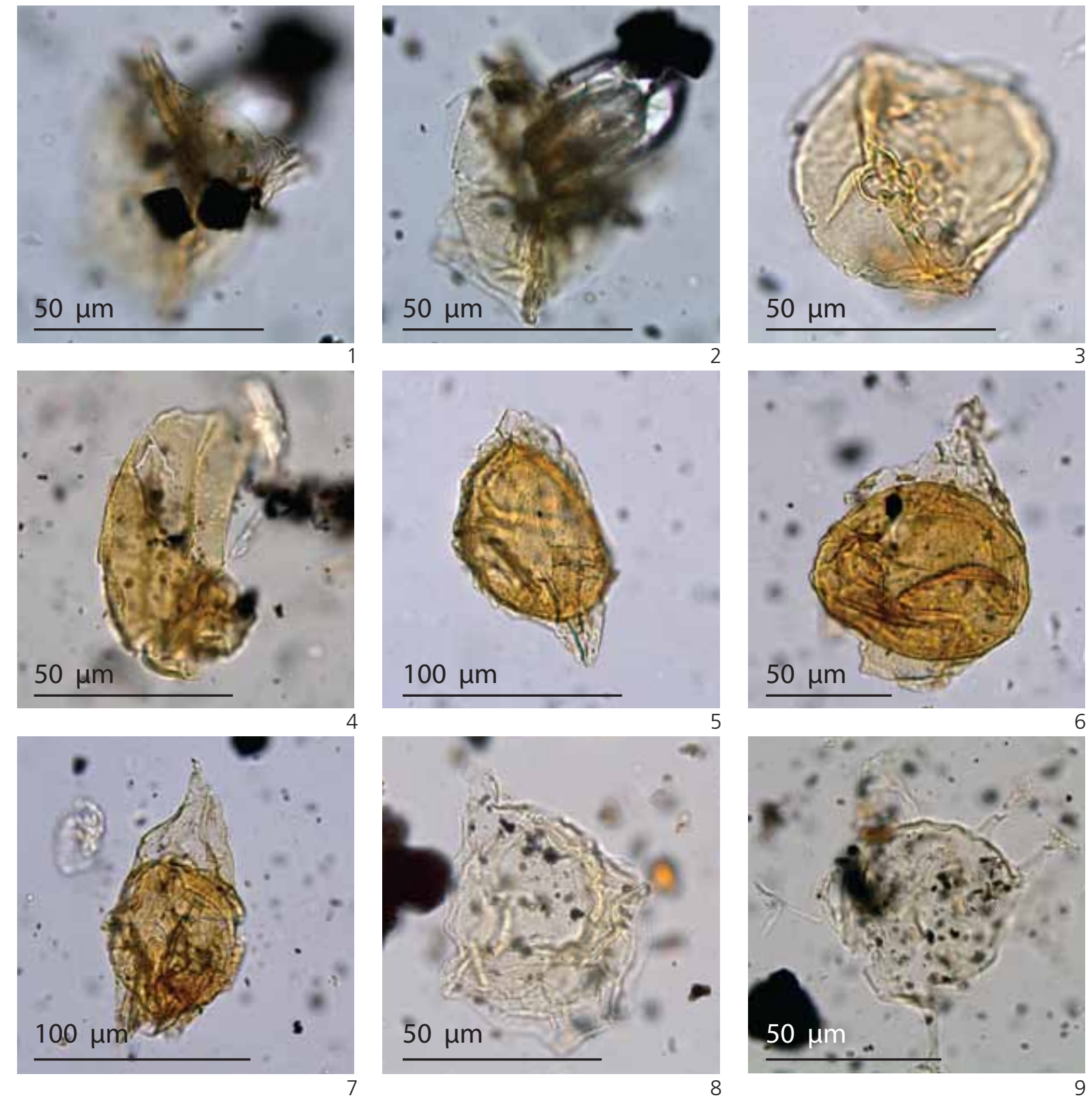

1 \& 2. Alterbidinium sp. Slide: L22558/1. England Finder: G39. (03-433 \& 03-439) 3. Alterbidinium asymmetricum. Slide: L22564/1. England Finder: O40. (08-263) 4. Deflandrea sp. Slide: L22562/1. England Finder: E35/4. (05-428) 5, 6 \& 7. Deflandrea antarctica. Slide: L22564/1 \& L22564/1. England Finder: V38/3, T35 \& W33/3. (08-156, 08-201 \& 08-132) 8. Deflandrea flounderensis. Slide: L22555/1 England Finder: M46 (01-272) 9. Enneadocysta partridgei. Slide: L22562/1. England Finder: B49/2 (05-503)

Plate 1. Dinoflagelletes. 

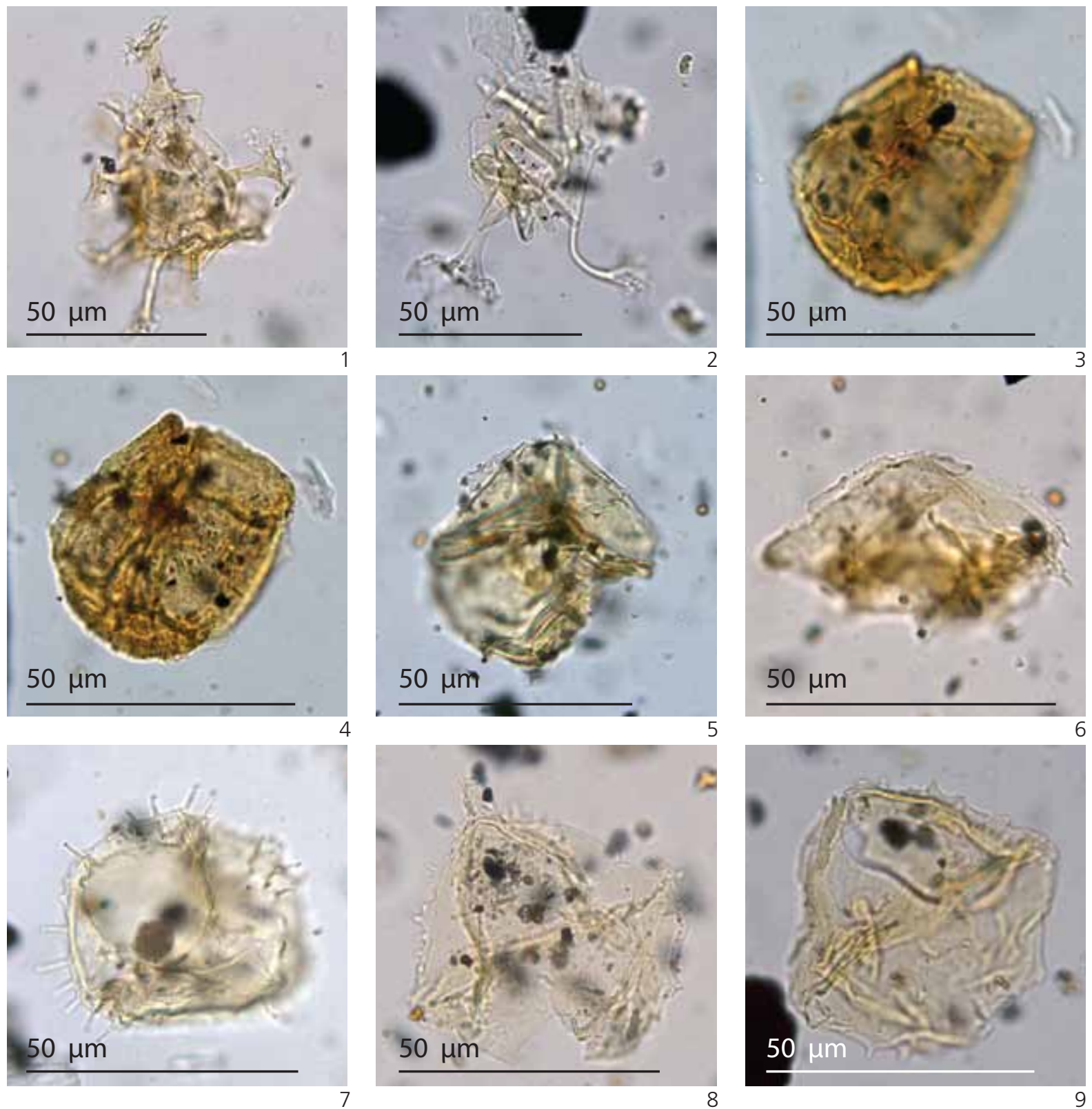

1 \& 2. Hystrichosphaeridium sp. Slide: L22560/1 \& L22564/1. England Finder: N34/3 \& F39/3. (04-327 \& 08-350) 3 \& 4. Impagidinium victorianum. Slide: L22566/1. England Finder: S35/13. (06-164 \& 06-166) 5 \& 6. Spinidinium sp. Slide: L22558/1 \& L22562/1. England Finder: P46 \& T32/1. (03-253 \& 05-268) 7. Spinidinium colemanii. Slide: L22555/1. England Finder: C35. (01500) 8 \& 9. Spinidinium macmurdoense. Slide: L22555/1. England Finder: R53 \& Q38. (01-201 \& 01-220)

Plate 2. Dinoflagelletes. 

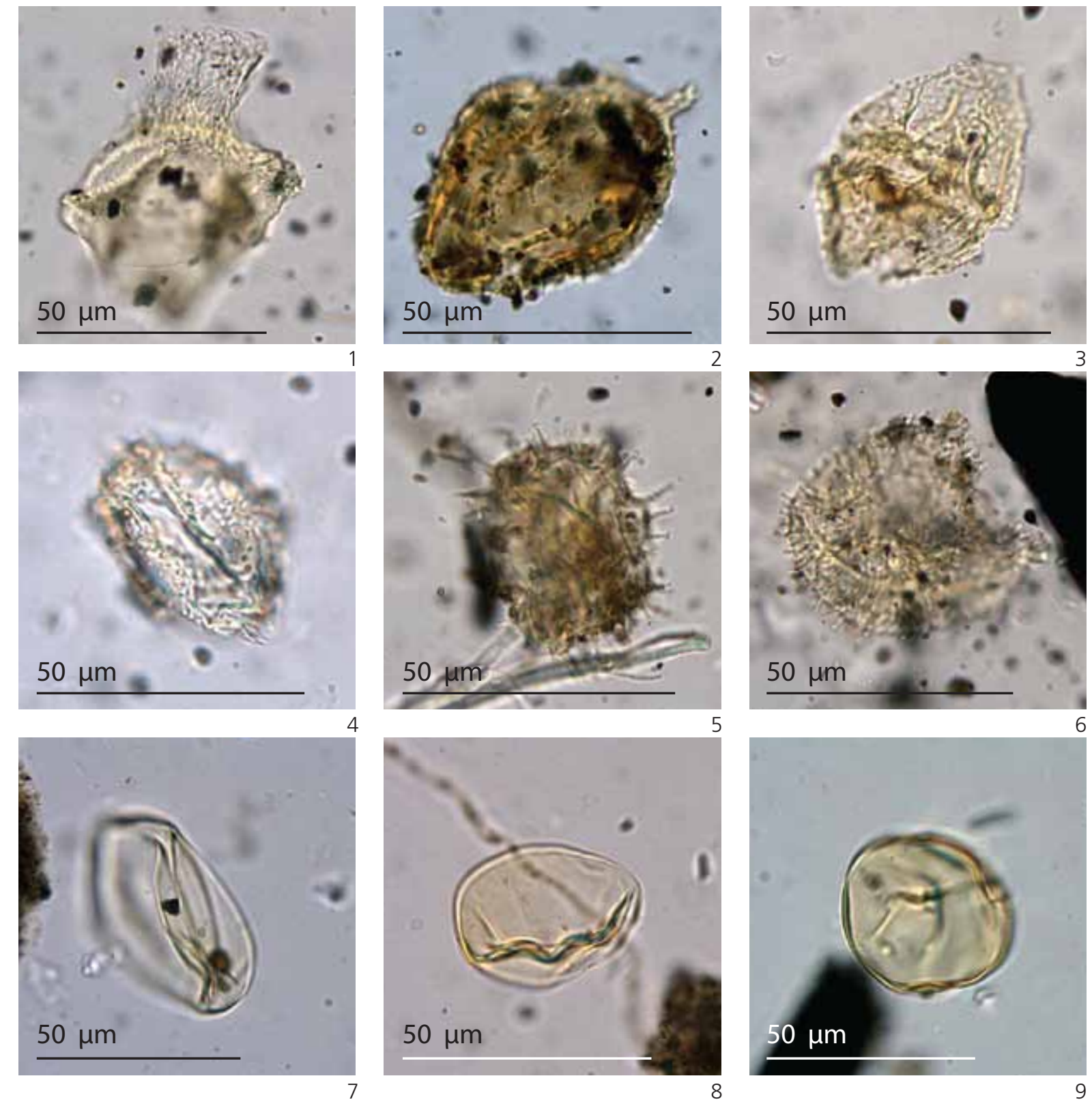

1. Turbiosphaera filosa. Slide: L22555/1. England Finder: G54. (05-440) 2, 3 \& 4. Vozzhennikovina apertura. Slide: L22558/1, L22555/1 \& L22564/1. England Finder: P37/1, H45/3 \& J29/3. (03-235, 05-349 \& 08-316) 5. Michrystridium sp1. Slide: L22555/1. England Finder: C35. (05495) 6. Michrystridium sp2. Slide: L22555/1. England Finder: J35. (05-334) 7, 8 \& 9. Leosphereidia spp. Slide: L22556/1, L22556/1 \& L22556/1. England Finder: T34, P37 \& K42/2. (09-244, $13-118$ \& 15-147)

Plate 3. Dinoflagelletes \& Acritarchs. 

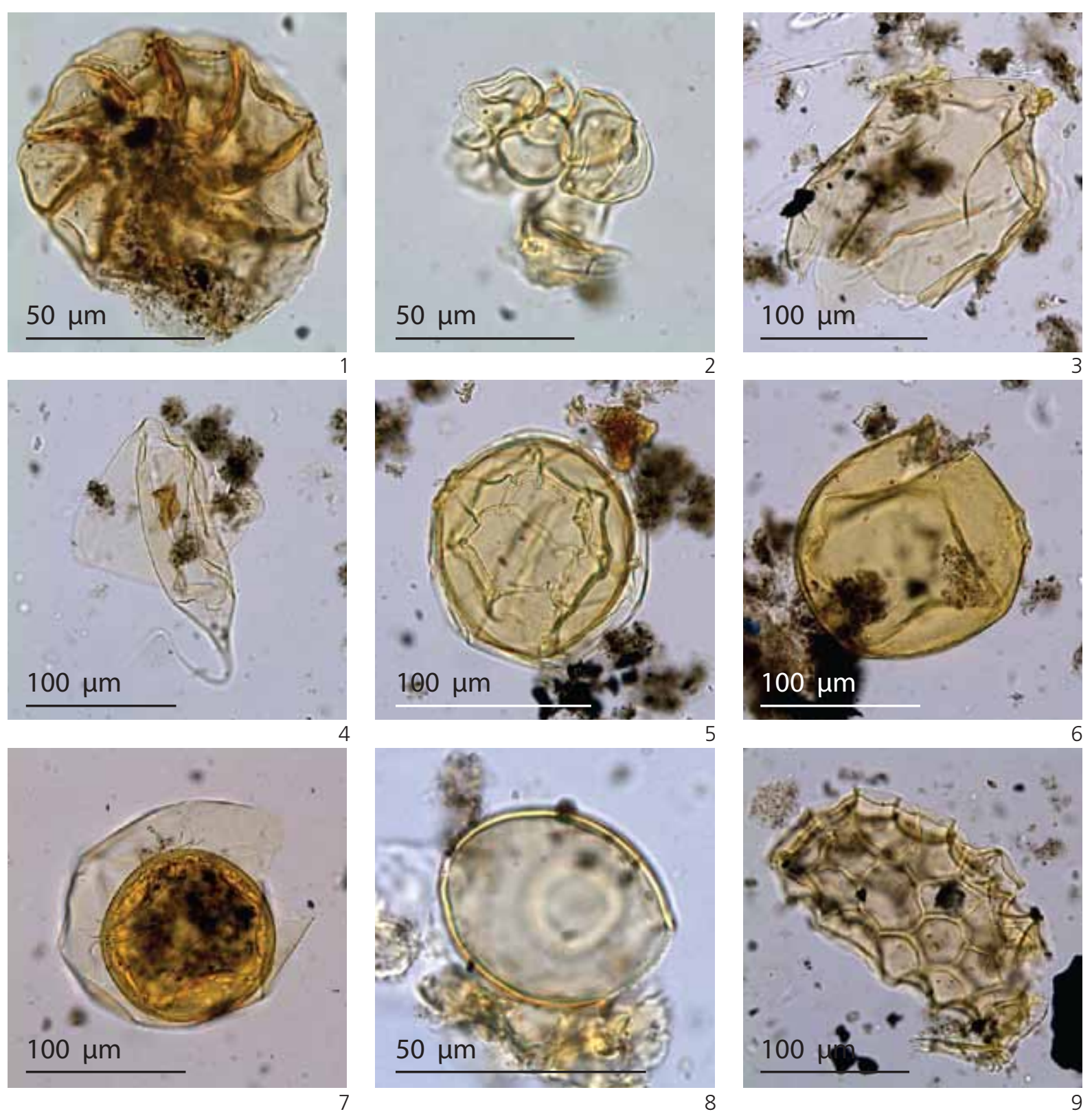

1 \& 2. Microforaminiferal linings. Slide: L22566/1 \& L22568/1. England Finder: G36/3 \& U35/2. (06-242 \& 15-121) 3. Zooplankton sp1. Slide: L22556/1. England Finder: Y46. (09-131) 4. Zooplankton sp2. Slide: L22556/1. England Finder: X43. (09-149) 5. Zooplankton sp3. Slide: L22556/1. England Finder: U48/2. (09-189) 6. Zooplankton sp4. Slide: L22556/1. England Finder: Q41. (09-320) 7. Zooplankton sp5. Slide: L22565/1. England Finder: T41/3. (13-105) 8. Zooplankton sp6. Slide: L22567/1. England Finder: T46/3. (14-129) 9. Zooplankton sp7. Slide: L22561/1 England Finder: V31. (11-114)

Plate 4. Zooplankton. 

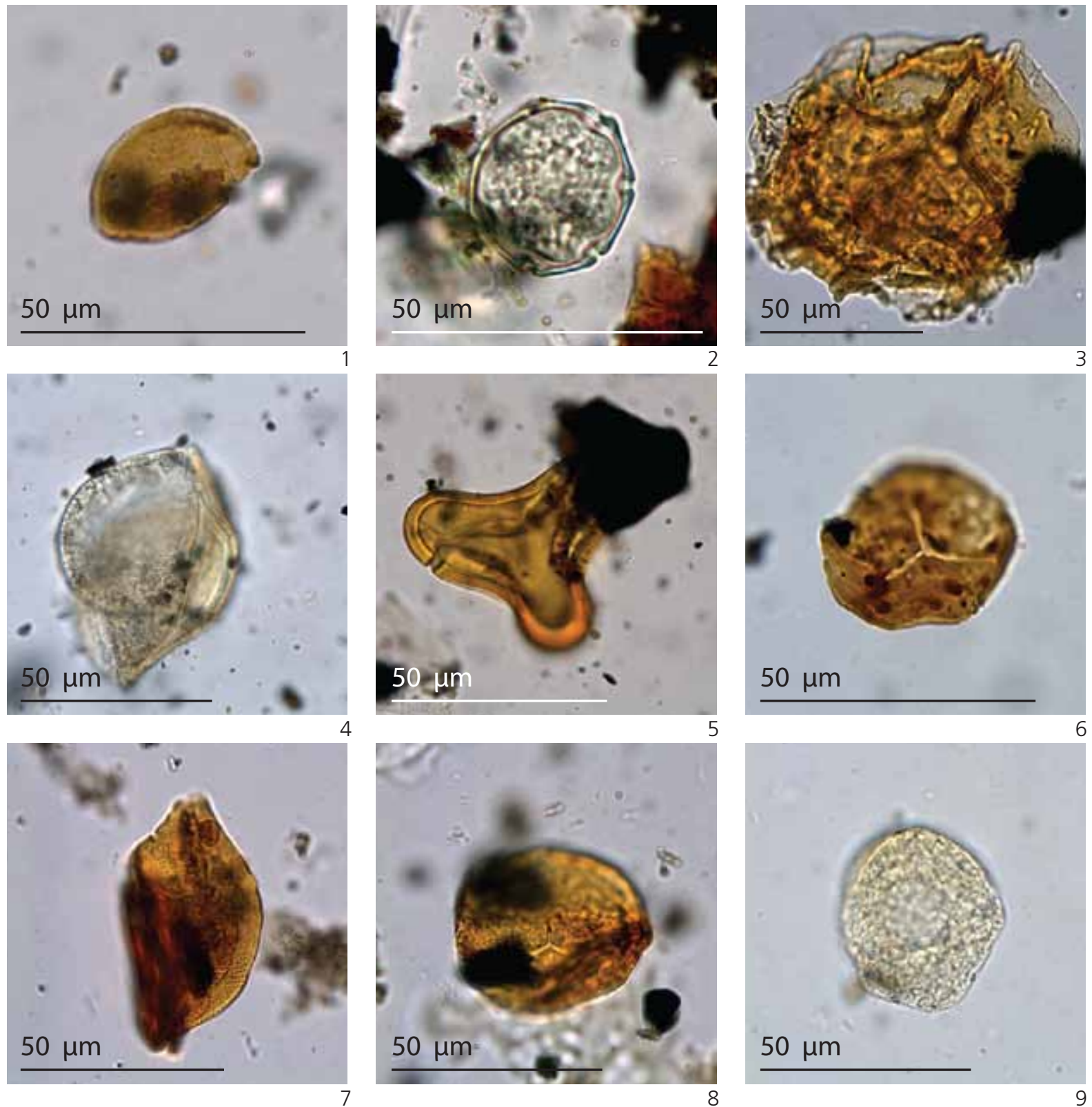

1. Terrestrial sp1. Slide: L22555/1. England Finder: N38/3. (01-256) 2. Terrestrial sp2. Slide: L22557/1. England Finder: R36/4. (02-168) 3. Terrestrial sp3. Slide: L22564/1. England Finder: V37/3. (08-170) 4. Terrestrial sp4. Slide: L22558/1. England Finder: D50/3. (03-489) 5. Terrestrial sp5. Slide: L22562/1. England Finder: W46/4. (05-181) 6. Terrestrial sp6. Slide: L22566/1. England Finder: R48/3. (06-171) 7. Terrestrial sp7. Slide: L22556/1. England Finder: Y51.(09-139) 8. Terrestrial sp8. Slide: L22559/1. England Finder: B43/3. (10-185) 9. Terrestrial sp9. Slide: L22568/1. England Finder: S46. (15-132)

Plate 5. Terrestrial. 


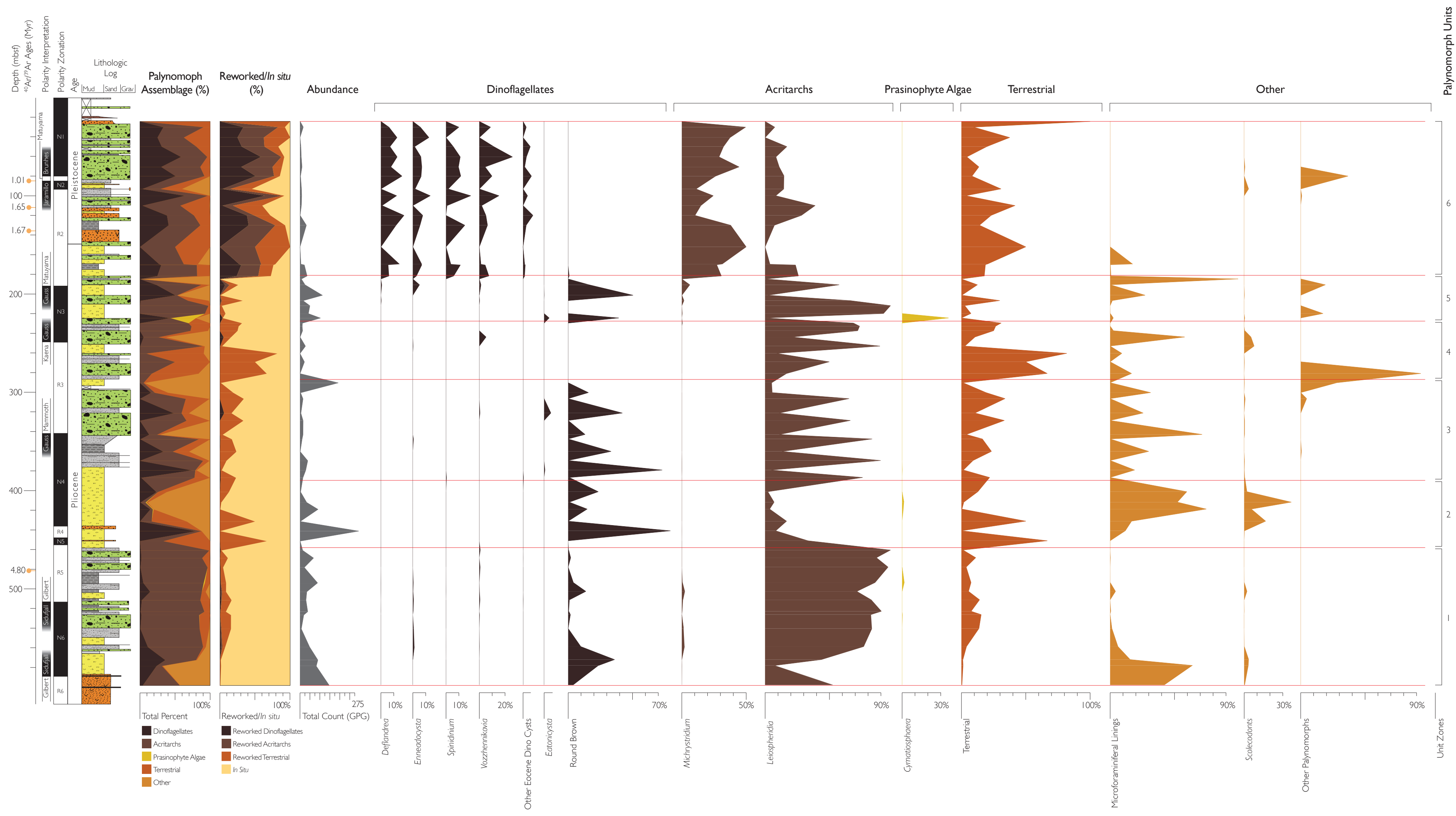

FIGURE 05 - The distribution of marine palynomorphs throughout the upper 600m of the AND-1B core shown as a percentage of the total palynomorph content. 


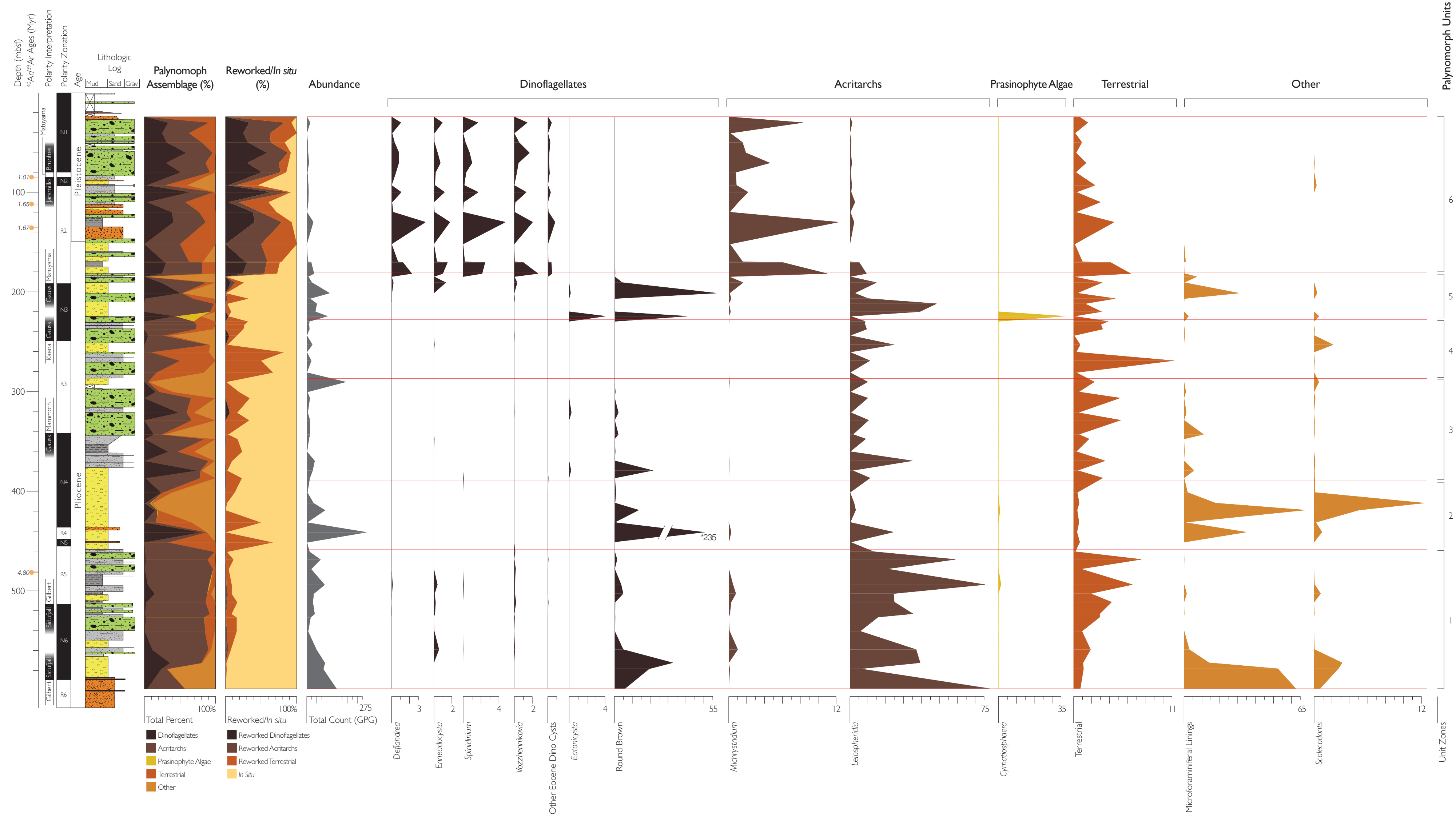

FIGURE 06 - The distribution of marine palynomorphs throughout the upper 600m of the AND-1B core shown as grains per gram of sediment (GPG). 


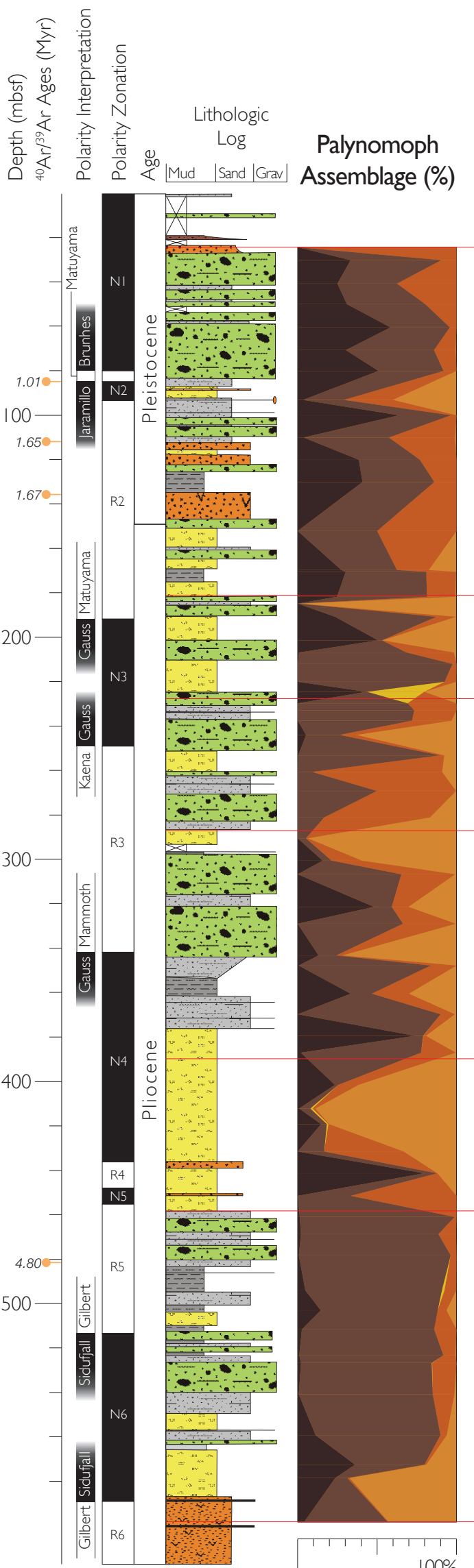

Reworked/In situ

\%) Abundance

Events

Trends

Interpretation

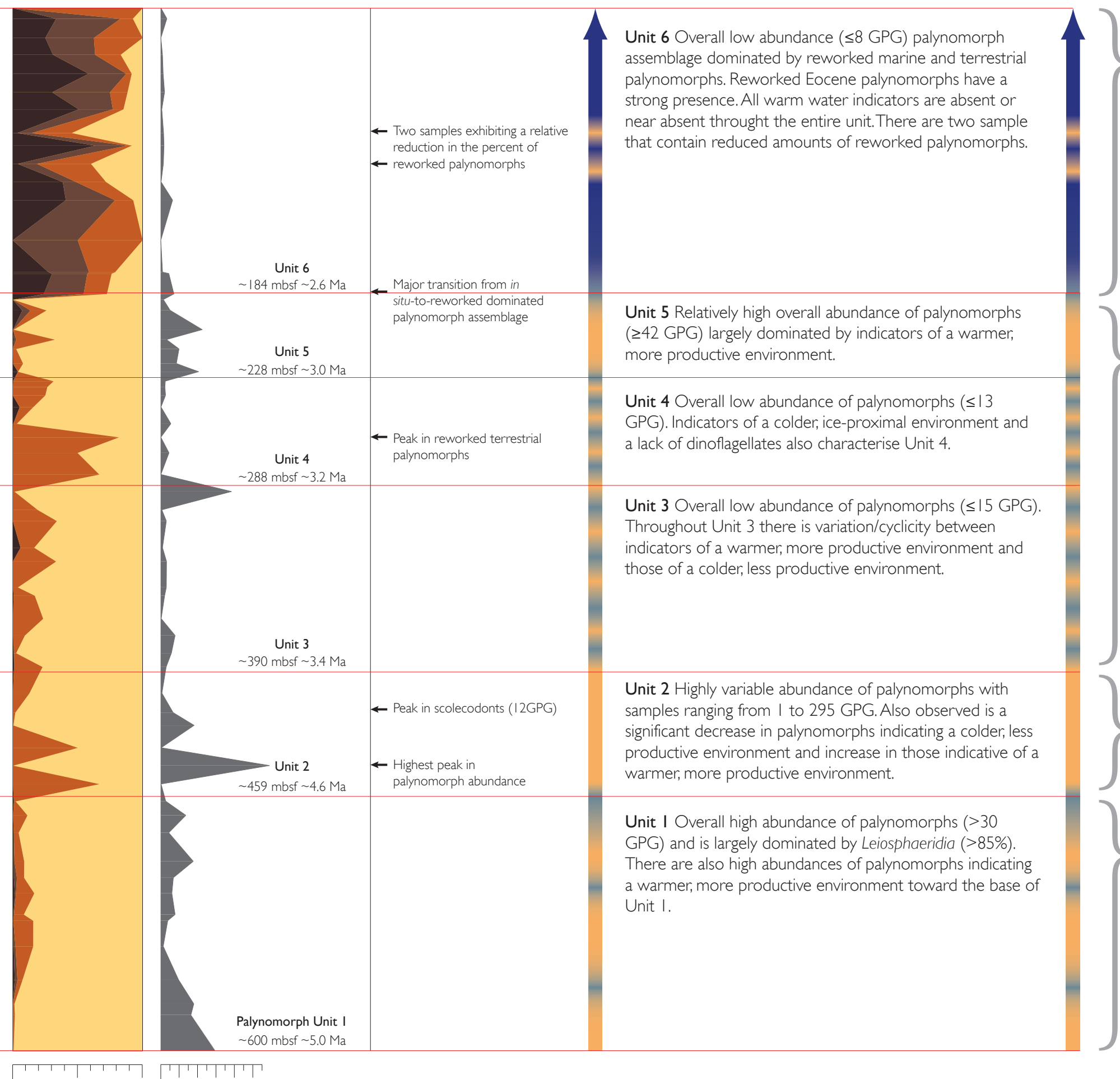

Coldest

作 reworked palynomorphs reflects a shift to 'polar' conditions
- Change within the reworked palynomorph assemblage

ts a change in provenance likely due to A stable WAIS existed inacial reconfifurartion state through Unit I, resulting in permanent ice cover or grounded ice persisting at the drill site. during superinterglacials.

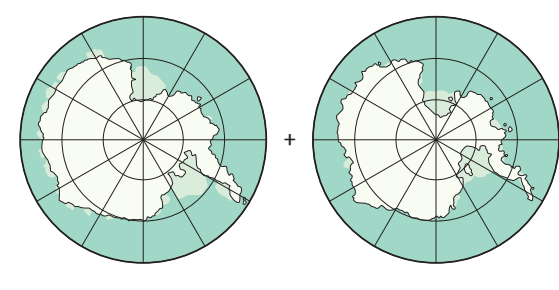

\section{Warm \& Variable}

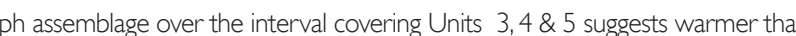
modem condtions with regularWAIS expansion \& reduction/collapse. - A reduction in palynomorph abundance and increase in percent of palynomorphs indicating a colder, coling trend with a palynomorph assemblage that suggests a significantly warmer, more productive Spike in the prasinophyte alga, Cymatiospheera, a

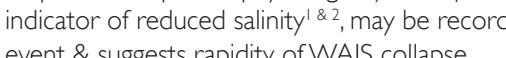
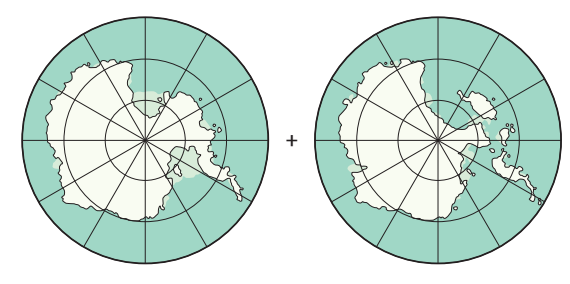

Warmest

Early-Mid Pliocene:

The gly free of ice during this $>$ I Ma period

Warmer than modern

Early Plocene

- High palynomorph abundances and dominance of oceanic productivity in the Ross Embarment sugs hig - Despite high productivity a constant presence of - Unit I exhibits indicators of greater productivity and - Conditions were warmer, and more productive modern with long intervals of a collapsed WAIS.
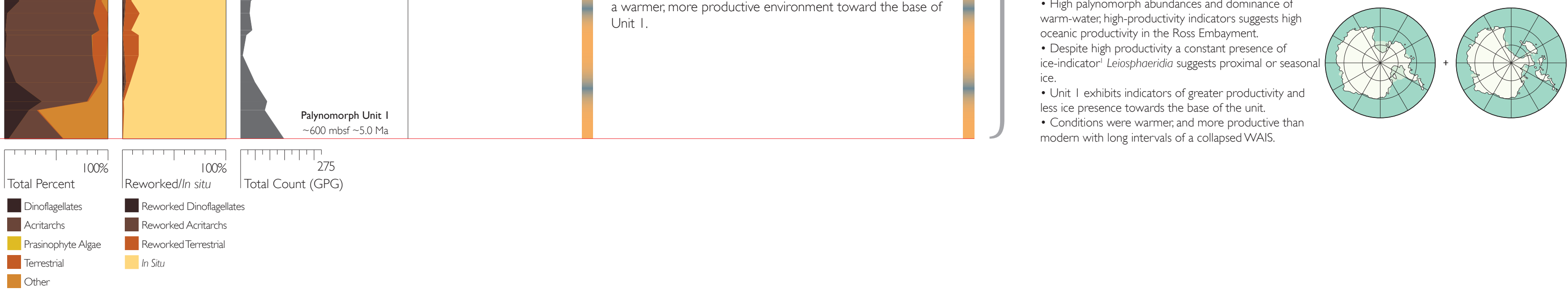

FIGURE 07 - A summary of the distribution of marine palynomorphs throughout the upper 600m of the ANDRILL AND-1B core. Antarctic reconstructions modified from Pollard \& DeConto (2009). 


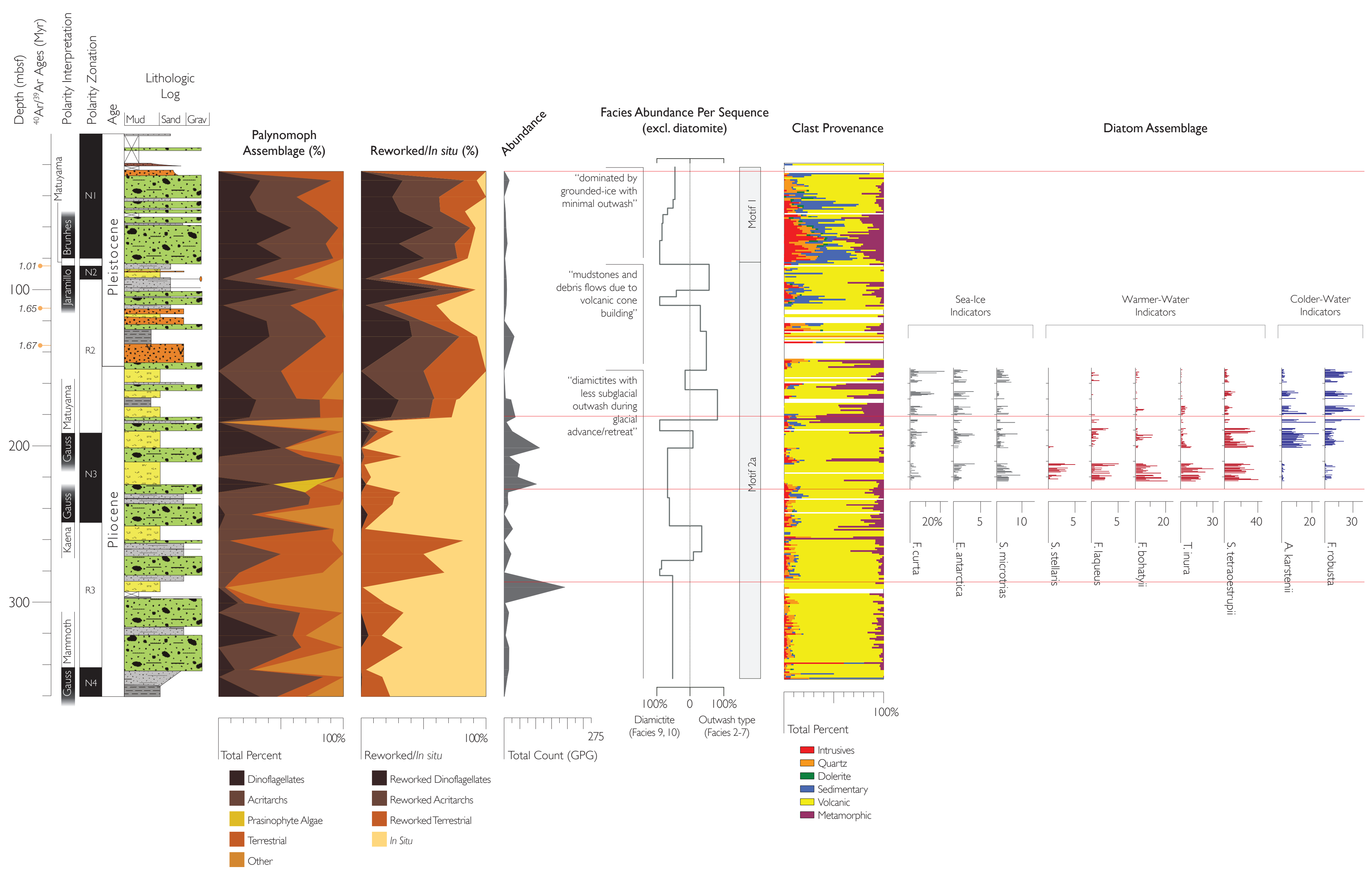

FIGURE 09 - Intergration of the results from the palynology analysis with other studies of the AND-1B core. Plotted against the palynomorph assemblage data are results from the sediment facies analysis (McKay et al. 2009), the clast provenance analysis (Talarico et al. 2010), and the diatom assemblage analysis (Sjunneskog \& Winter, unpublished). 
